Historic, Archive Document

Do not assume content reflects current scientific knowledge, policies, or practices. 

United States

Department of

Agriculture

Forest Service

Tongass

National

Forest

R10-MB-261

September 1994

Uis
Ushk Bay Timber Sale(s)

Final Environmental Impact Statement

Record of Decision

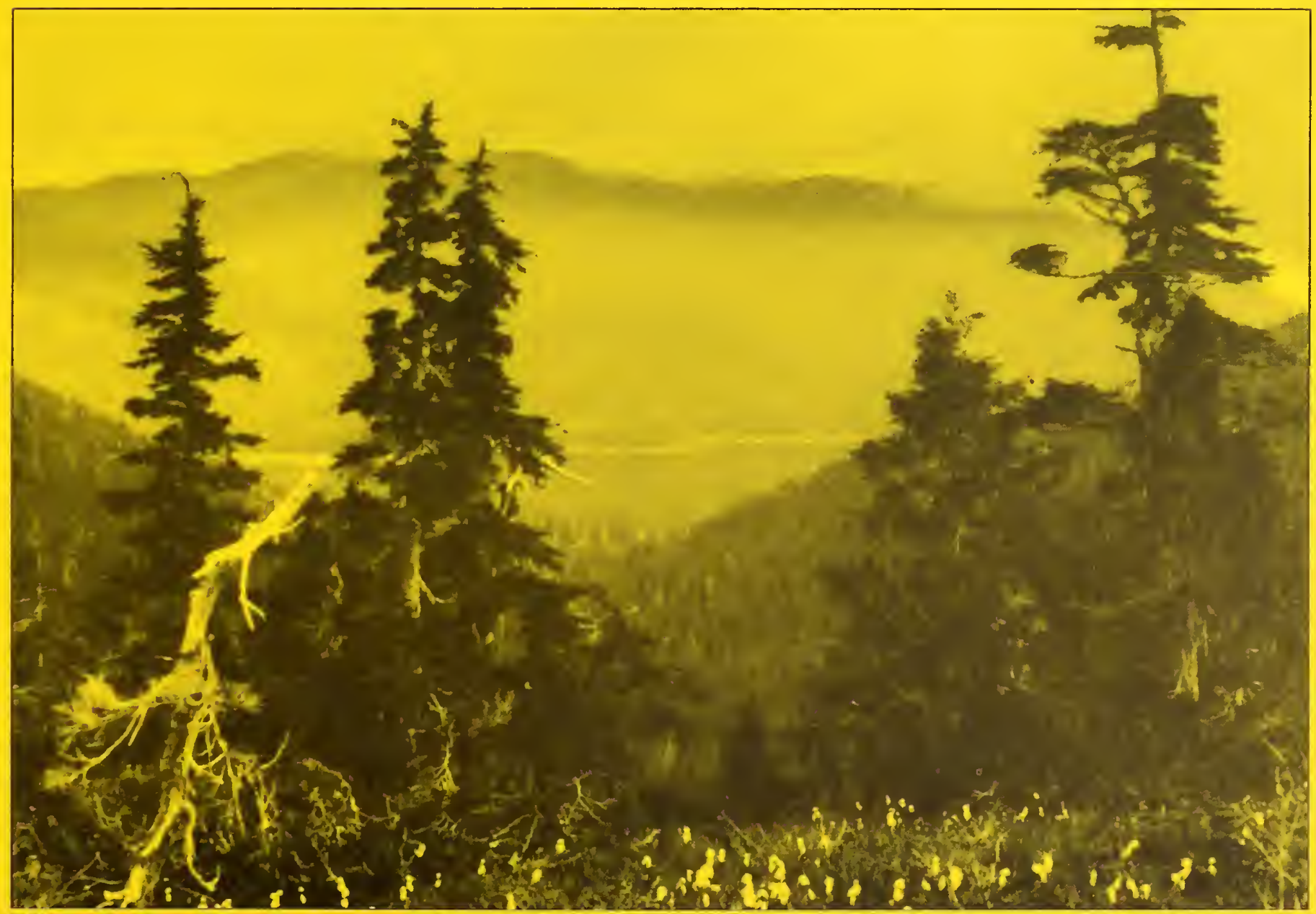


United States

Department of

Agriculture

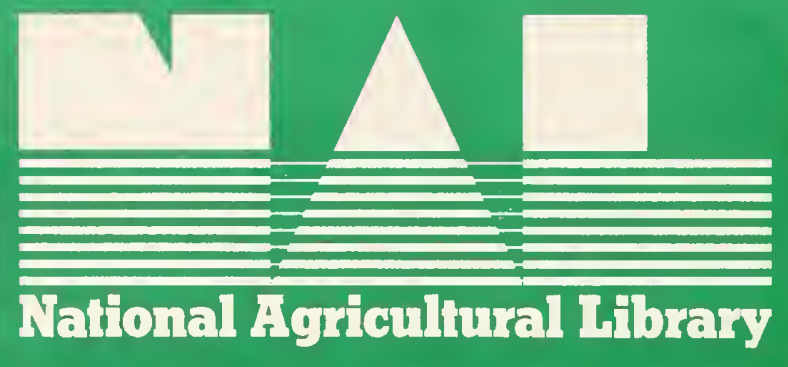




\section{Reply To: 1950}

Date: August 5, 1994

Dear Reader:

Attached is the Record of Decision (ROD) for the Ushk Bay timber sales. If you requested complete documentation of this decision, the following items should be found in the package:

Record of Decision

Summary

Volume I: Final Environmental Impact Statement (EIS)

Volume II: Appendices A - O

If you requested the quick review documentation of this decision, the package should include only the ROD and Summary. Copies of the entire Final EIS are available for review at Forest Service offices in Juneau, Hoonah, Sitka, Petersburg, Wrangell, and Ketchikan. Copies have also been sent to libraries throughout Southeast Alaska.

The ROD documents my final decision on the selection of an alternative, and the factors considered in reaching the decision. The Effective Date of Implementation for the decision and the Notice of Rights of Appeal are also specified in the ROD.

I want to thank those of you who took the time to review and comment on the Draft Environmental Impact Statement and also those who participated in the Subsistence Hearings. Your interest in the management of the Tongass National Forest is appreciated. I also want to extend a special thank you to those who requested the quick review documentation of this decision in lieu of the entire set of the Final EIS.

Sincerely,

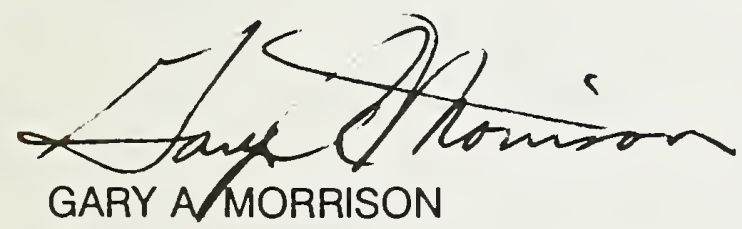

Forest Supervisor

Enclosures

9408021115 IDT1 $1950 \mathrm{MW}$ 



\title{
Ushk Bay Timber Sale(s) \\ Final Environmental Impact Statement
}

\author{
Record of Decision
}

\author{
U.S.D.A. Forest Service, Alaska Region \\ Tongass National Forest, Chatham Area \\ Sitka Ranger District
}
Lead Agency U.S. D. A. Forest Service
Tongass National Forest, Chatham Area
204 Siginaka Way
Sitka, Alaska 99835

\begin{tabular}{|c|c|}
\hline $\begin{array}{l}\text { Responsible } \\
\text { Official }\end{array}$ & $\begin{array}{l}\text { Gary A. Morrison, Forest Supervisor } \\
\text { Tongass National Forest. Chatham Area }\end{array}$ \\
\hline $\begin{array}{l}\text { For Further } \\
\text { Information, } \\
\text { Contact }\end{array}$ & $\begin{array}{l}\text { Michael J. Weber, Team Leader } \\
\text { U.S.D.A. Forest Service } \\
\text { Tongass National Forest, Chatham Area } \\
204 \text { Siginaka Way } \\
\text { Sitka, Alaska } 99835 \\
\text { (907) } 747-6671\end{array}$ \\
\hline
\end{tabular}





\section{Contents}

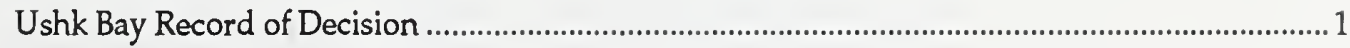

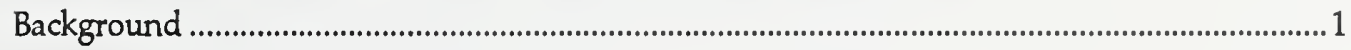

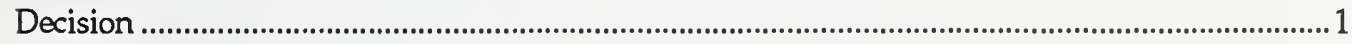

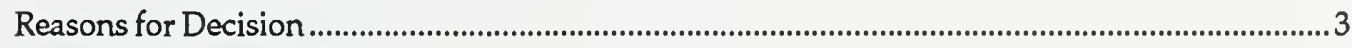

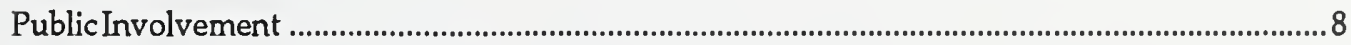

Coordination with Other Agencies ..............................................................................................

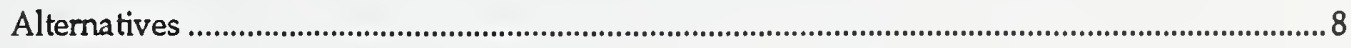

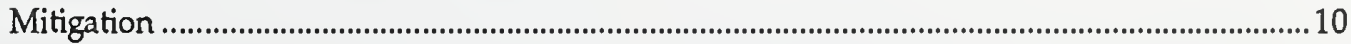

Monitoring and Enforcement .............................................................................................. 11

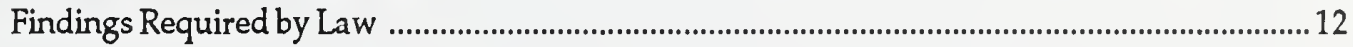

Implementation of This Decision .................................................................................................... 16

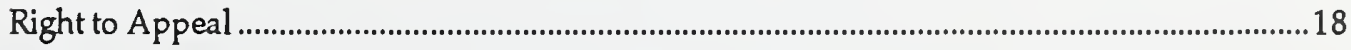

Appendix 1 Poison Cove Selected Alternative Volumes; Ushk Bay Selected Alternative Volumes; Post-harvest Silvicultural Treatments; Enhancement Opportunities

Appendix 2 Road and Unit Cards Not Included in the Final EIS

Appendix 3 Road Management Objectives (RMOs) for the Selected Alternative

Appendix 4 Proportion of Volume Classes 6 and 7 Planned for Harvest for the Selected Alternative

Appendix 5 Monitoring 



\section{Record of Decision}

\section{Ushk Bay Record of Decision}

\section{Background}

The purpose and need for the Ushk Bay project is to make timber available, under the direction contained in the Tongass Land Management Plan and its amendments, to help meet market demand and to establish managed stands capable of long-term timber production.

Analysis of the demand for timber volume through 1995, under terms of the revised long-term contract with Alaska Pulp Corporation (APC), indicated that between 55 and 100 million board feet of volume would need to be made available from the Ushk Bay Project Area in 1994. However, the April 14, 1994, contract termination decision ended APC contract volume obligations. In May, 1994, an independent sale program market assessment (Morse 1994) was completed. The assessment indicates that the Ushk Bay volume is still needed to contribute to the projected independent sale program (Final EIS, Appendix O, Enclosure 1). The Ushk Bay Project was one of a series of timber harvest projects that were being considered within the APC contract boundary. These projects will now contribute to the independent sale program and the Ketchikan Pulp Company contract (Final EIS, Appendix O, Enclosure 2). See Final EIS Appendix A for a discussion of how Ushk Bay was selected.

An evaluation was done on whether the change from a long-term timber sale contract offering to independent timber sales, and other information that has become available since the Draft EIS, constituted significant new circumstance or information relevant to environmental concerns to warrant preparing a supplement to the Draft EIS. The determination was that a supplement to the Draft EIS was not needed before releasing the Final EIS and Record of Decision (ROD). The evaluation is included in Appendix $O$ of the Final EIS.

Public scoping, data gathering and analysis, and document production began with publication of the Notice of Intent in the Federal Register May 8, 1992. The Notice of Availability for the Draft EIS was published in the Federal Register June 11, 1993, and the public comment period for the Draft EIS closed August 25, 1993. This ROD and Final EIS disclose the environmental effects of the alternatives considered and document the decision for authorization of activities within the Project Area.

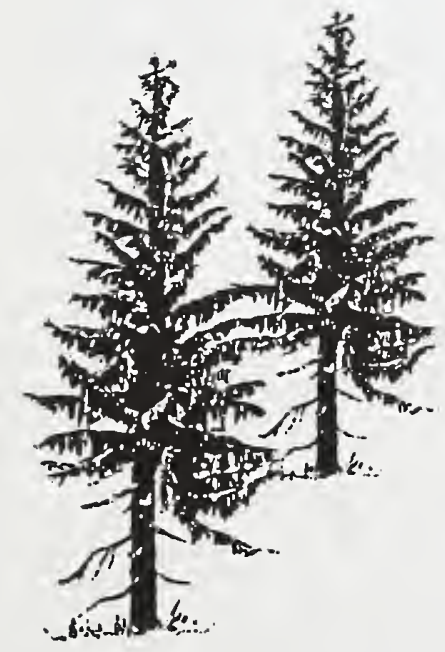

\section{Decision}

This Record of Decision documents my decision to select the timber harvest areas to be made available from the Ushk Bay Project Area. My decision includes the following:

- The volume to make available in this area through independent timber sales;

- The location of independent sales;

- The location of timber harvest units;

- The location of road systems;

- The location of log transfer facilities; 
- Mitigation measures and enhancement opportunities for resources other than timber, and

- Whether there may be a significant restriction on subsistence uses.

It is my decision to select Alternative $\mathrm{F}$ with modifications, as shown on the Selected Alternative map (Figure R-1), for implementation in the Ushk Bay Project Area. This decision is most responsive to the issues raised during scoping, data gathering and analysis, public responses to the Draft EIS, and testimony received at the subsistence hearings.

Specifically, my decision authorizes the following:

1. Approximately 2,166 acres of commercial forest land will be harvested. Implementation is expected to occur in two independent timber sales. This specified harvest will provide approximately 54 million board feet of sawlog volume and 13 million board feet of utility volume for a total of 67 million board feet. There will be 60 timber harvest units. Table 1 lists the expected independent sales and the sale locations are shown on Figure R-2. ROD Appendix 1 lists each unit, by timber sale, approved for harvest under the Selected Alternative. Design features of the timber harvest units are described in detail on the unit cards in Final EIS Appendix C and ROD Appendix 2.

Table 1

\section{Independent Timber Sales}

\begin{tabular}{lcccc} 
Timber Sale & $\begin{array}{l}\text { Volume } \\
(\mathrm{MBF})\end{array}$ & Sale Date & Duration & $\begin{array}{c}\text { Est. Net } \\
\text { Stumpage } \\
\text { Value }\end{array}$ \\
\hline Poison Cove & 27,409 & 1995 & $2-3$ yrs. & $\$ 12.40$ \\
Ushk Bay & 39,795 & 1996 & $3-4$ yrs. & $\$ 2.94$ \\
\hline Source: Regan, 1994 & & & & \\
\hline
\end{tabular}

2. I modify Alternative $\mathrm{F}$ by removing the following harvest units and roads from the Alternative:

- VCU 279: Unit 33

- VCU 280: Units 19, 20, 21, 21A, 22, 22A, 23, 138, 138A; Roads 7518, 75188, 75189

- VCU 281: Units 37A, 67, 68, 78B, 78C, 78D, 78E, 5A, 81, 79B; Portions of roads $75186,7516 \mathrm{~N}$

3. I also add the following units and roads from Alternative $\mathrm{C}$ as it is displayed in the Final EIS:

- VCU 279: Units 110, 116, 117, 118, 119, 50, Groups I and II; a portion of Road 7518

- VCU 280: Units 118,119

- VCU 281: Units 39, 14, Groups II and III; a portion of road 7518

4. I also add the following units from Alternative $\mathrm{E}$ as it is displayed in the Final EIS:

- VCU 279: Unit 105

- VCU 281: Units 2, 93 


\section{Record of Decision}

5. I also substitute the following units from Alternative $\mathrm{E}$, as displayed in the Final EIS, for the same units in Alternative $\mathrm{F}$ that have a different configuration:

- VCU 280: 36

- VCU 281: $3,16 \mathrm{~A}, 37,86 \mathrm{~A}, 72$

6. The Selected Alternative includes construction of 27.0 miles of new system road, and construction of 15.4 miles of temporary road in order to access the specified timber harvest units. Appendix $\mathrm{C}$ of the Final EIS contains the Road Cards with specific direction for the location of each road. ROD Appendix 3 lists the roads and their respective road management objectives for future management of the transportation system.

7. A temporary drive-down log transfer facility (LTF) for nonviolent entry operations, as defined by the Alaska Timber Task Force (less than three feet per second), will be constructed on the south side of Poison Cove. This will be constructed at a -12 percent grade which will require approximately 2,500 cubic yards of clean shot rock fill. This will be used to transfer logs to the water for timber harvest in VCUs 281, 280, and 279. Associated with the Poison Cove log transfer facility will be an upland camp for the logging families, and other support activities needed to make the camp workable (boat dock, fuel storage, sort yard, rafting areas, etc). Another temporary drive-down LTF for nonviolent entry operations will be constructed at a new location at Goal Creek as shown on Alternative $\mathrm{C}$. This will be constructed at a $-15 \%$ grade which will require approximately 1,500 cubic yards of clean shot rock fill. This will be used to transfer logs to the water for timber harvest in VCUs 279 and 280.

8. A log sorting area will be constructed close to the Poison Cove LTF site. No sorting area will be utilized at the Goal Creek LTF site due to the relatively small amount of timber being transferred.

9. This Record of Decision identifies required mitigation measures to reduce or eliminate adverse environmental effects of the timber harvest and road construction activities specified in the Selected Alternative. Appendix I of the Final EIS and ROD Appendix 5 presents the implementation and effectiveness monitoring that will be conducted to determine how well the resource management objectives have been met.

10. In addition, the description of the Selected Alternative shows enhancement opportunities that are feasible following implementation of this alternative. These opportunities will be included in Sale Area Improvement plan(s) developed in conjunction with each sale.

11. Finally, I have determined that there is a significant possibility of a significant restriction on subsistence use of deer in the Project Area and that this action will in part contribute to that possibility, but that: (a) these actions are necessary, consistent with sound management of public lands; (b) the amount of public land involved to implement the Selected Alternative is (considering sound multiple-use management of public lands) the minimum necessary; and, (c) reasonable measures to minimize impacts on subsistence have been adopted to the maximum extent practicable while still meeting the purpose and need for this project.

\section{Reasons for Decision}

In making my decision, I worked to ensure consideration of all issues, taking into account the competing interests and values of the public who participated in this project. I believe the decision is reasonable. The Selected Alternative continues to provide a beneficial mix of resources and uses to the public within the framework of the existing laws, regulations, poli- 


\section{Record of Decision}

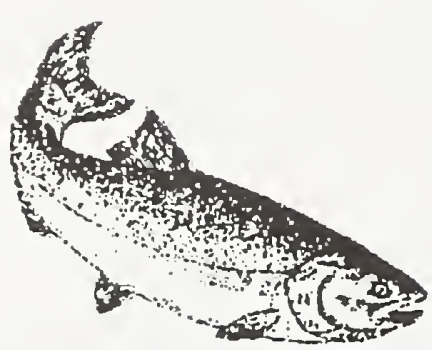

cies, public needs and desires, and capabilities of the land, while meeting the stated purpose and need for this project.

My decision to implement this Selected Alternative is consistent with the Tongass Land Management Plan (TLMP) as amended, and sound National Forest management. I have considered the need to help maintain an adequate timber supply in support of community stability. I have also considered the need to provide strong protection measures for fish, wildlife, and other resources important to subsistence, recreation, commercial, and other uses.

The units and roads in the Deep Bay drainage are deleted from the Selected Alternative because of the unresolved Native allotment claim at the head of Deep Bay .

Units $5 \mathrm{~A}, 33,37 \mathrm{~A}, 78 \mathrm{~B}, 78 \mathrm{C}, 78 \mathrm{D}, 78 \mathrm{E}, 79 \mathrm{~B}$, and 81 are deleted and the boundaries of Units $4,5,8,11,12,27,28,29,30,30 \mathrm{~A}, 31,35,72,37,74 \mathrm{~A}, 75,77,79,79 \mathrm{~A}, 82,86,90,101$, and 105 are adjusted, as reflected on the unit cards in ROD Appendix 2, because of fisheries, watershed, visuals, or windfirmness concerns. Units 40 and 93 are in the Alternative $F$ and $E$ configurations respectively, but they will be helicopter yarded. Unit 39 (Alternative $\mathrm{C}$ configuration) has been broken into two units, with Unit 39 in the Ushk Bay Sale and Unit 39A in the Poison Cove Sale. Both will be helicopter yarded. Units $4 \mathrm{~A}$ and $30 \mathrm{~B}$ are a result of a middle portion of the original units 4 and 30 being dropped for fisheries and watershed concerns.

Units 14, 39, 50, 110, 116, 117, 118, 119, Group I, Group II, and Group III from Alternative C and units 2, 3, 36, 37, 72, 86A, 93, and 105 from Alternative E are included in the Selected Alternative in order to offset the timber volume lost by deletions of units or portions of units in Alternative $\mathrm{F}$, in order to meet the purpose and need for this project.

Uneven-aged silviculture or selective harvest is a relatively new silvicultural system in Southeast Alaska. The Ecosystem Management Strategy for Forest Service Programs in Alaska, item I.C.(5), signed in October 1992, requires that the Forest Service test the applicability of silvicultural methods other than clearcutting on selected timber projects. The areas for which uneven-aged silviculture is prescribed (Groups I, II, and III) were identified and designed to ensure the success of the prescription. This includes removing a portion of the trees in small patches, two acres or less in size, within the Groups, while successfully retaining natural regeneration and the other trees around the small patches. The specific logging plan for each area of selective harvest is described on the Unit Cards and an Integrated Silvicultural Prescription will be prepared prior to implementation. Sale administrators will ensure that the logging operations accomplish the harvest objectives for these units. Implementation of these prescriptions is intended to add to our knowledge of alternate treatments for Southeast Alaska timber types.

At this time, the Pacific Northwest Research Station Forest Sciences Lab is initiating a formal study to evaluate alternatives to clearcutting. This study is in the early stages of planning. It is possible that some of the units in the Selected Alternative for Ushk Bay will be included in the study.

How Issues Are

In the following summary, I detail how the Selected Alternative addresses each of the significant issues. The list of issues is revised from the DEIS because Issue 2, Timber Resources, in the DEIS is basic to the Purpose and Need and does not affect the alternatives. It was determined not to fit the definition of a significant issue (see Chapter 1 of the FEIS). Refer to Table 3 of this Record of Decision to supplement the following discussion and provide a comparison of the FEIS alternatives and the Selected Alternative.

Issue 1: Will the proposed timber harvest and road construction activities adversely affect subsistence uses? 


\section{Record of Decision}

This issue reflects public concern for the availability of wildlife, marine life, and plants for customary and traditional use by rural Alaska residents.

The Alaska National Interest Lands Conservation Act (ANILCA) requires the Forest Service to determine if proposed activities may significantly restrict use of subsistence resources. If such a finding is made, then ANILCA requires public hearings and determinations regarding actions to minimize impacts prior to proceeding with a project.

Chapter 4 of the Final EIS contains the ANILCA 810 subsistence analysis. In summary, the analysis concludes that there is a significant possibility of a significant restriction of subsistence use of Sitka black-tail deer in the Project Area for the communities of Haines, Petersburg, Sitka, and Wrangell. This is a possibility regardless of which alternative is implemented, including the No-Action Alternative. Among these four communities, there is sufficient habitat capability in Wildlife Analysis Areas (WAAs) hunted by community residents to meet subsistence needs of all communities in the foreseeable future except for Sitka. The analysis also concludes that there is a significant possibility of a significant restriction on fish and shellfish based on changes in access during the period of active timber harvest for alternatives that include an LTF or logging camp in Ushk Bay. The Selected Alternative excludes LTFs and logging camps from Ushk Bay. The foreseeable effects of the action alternatives do not represent a significant possibility of a significant restriction for other resources used for subsistence.

Access to historic subsistence-use areas may be affected where logging activities (LTFs, logging camps) are located in the beach fringe. This is because traditional subsistence access is by boat to the beaches of the Project Area. Motor vehicle access is provided only by barge or boat since the Alaska Marine Highway ferries do not stop within the Project Area. Because of this limited access, only a minor increase in access to the area is expected. Roads will be located away from the beaches and Road Management Objectives for the Selected Alternative discourage vehicular access.

Any displacement of subsistence users that may occur is likely to be to other areas within a household's or community's historical range. None of the four potentially restricted communities averaged more than 7 percent of its subsistence harvest of deer from the Project Area during 1987 to 1991 . The community of Sitka averaged 7 percent and the other three communities averaged one percent or less. Furthermore, any displacement that may occur would likely be temporary until activities within the Project Area conclude in 3 to 5 years.

The Selected Alternative reflects efforts of the Forest Service to minimize effects on subsistence resources used by those rural communities that would be most likely to receive the highest priority for game in the event of an ANILCA Section 804, Tier II restriction. The Selected Alternative eliminates timber harvest in the Deep Bay watershed which avoids potential subsistence conflicts with an LTF in Deep Bay and reduced habitat capability for subsistence species. No logging camp or LTF will be developed in Ushk Bay to avoid, to the extent practicable, conflicts with subsistence access, competition and resource abundance in this portion of the Project Area. Road Management Objectives, as mentioned above, will discourage vehicular access, which will reduce the potential for increased competition from all terrain vehicle (ATV) users.

Issue 2: How will the timber harvest and road construction activities affect recreation and visual resources?

This issue addresses concerns for outdoor recreation and scenic viewing opportunities offered in and around the Ushk Bay Project Area and the effects timber harvest and transportation system development may have upon these opportunities. 


\section{Record of Decision}

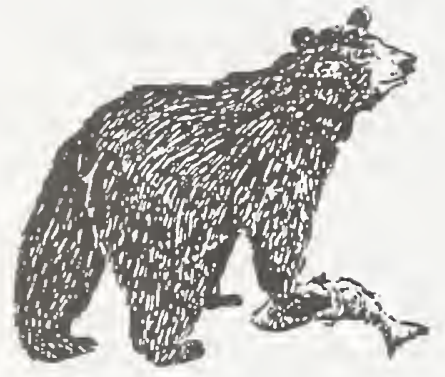

The Selected Alternative will result in an overall decrease in acres of Primitive and Semiprimitive Non-motorized opportunities of 32 percent, for the Ushk Bay Project Area as a whole. However, the Project Area contains only a small amount of the total recreation opportunities on the Tongass National Forest, and there are similar recreation opportunities nearby. The Upper Hoonah Sound LUD II area, the West Chichagof-Yakobi Wilderness, and the proposed Big Bear/Baby Bear Bays State Marine Park are immediately adjacent to the Project Area. In addition, the favorite anchorages in Ushk and Deep Bays, and overall scenic quality in Deep Bay, will not be affected by the Selected Alternative. None of the constructed road system will be maintained open following project completion.

Timber harvest activities would take place in three Value Comparison Units (VCUs). Ushk Bay, Poison Cove, and Deep Bay VCUs would be scheduled for some level of harvest with the Selected Alternative. The level of timber harvest and road construction will result in either a Modification or Maximum Modification Visual Quality Objective along Peril Strait from Ushk Bay to Goal Creek. No timber harvest activities will be visible in the Project Area along Peril Strait south of Goal Creek or from within Deep Bay. Selective harvest is prescribed for units in visually sensitive areas along Peril Strait to mitigate visual impacts. The LTFs planned for development in Poison Cove and at Goal Creek would have a strong visual impact when viewed from the foreground, and little, if any, visual effect from background views (Final EIS, Chapter 4). No LTF or logging camp facility will be located in Ushk Bay. Roads and harvest activity will be located away from the Ushk Bay beach to minimize impacts.

Issue 3: What effects will timber harvest and road construction activities have on the Native allotment land claim at Deep Bay?

This issue addresses concerns about impacts to an area at the head of Deep Bay that is an unresolved Native allotment land claim.

The Selected Alternative eliminates timber harvest and road constriction in the Deep Bay drainage, which avoids any impacts to the Native allotment land claim.

Issue 4: What would be the economic and social effects of logging and associated development on Southeast Alaska residents?

This issue reflects concerns about community employment and stability, and maintaining Alaskan lifestyles.

Implementation of the Selected Alternative authorizes harvest of approximately 67 million board feet of timber volume. Additionally, it authorizes 42.5 miles of road construction and construction of two LTFs. Specified harvest of this level maintains approximately 303 jobs directly related to timber harvest, road construction, and wood product processing. This level of harvest also maintains approximately 72 jobs in indirect employment associated with the service and support sectors. This results in 375 jobs maintained, with a value of $\$ 13.2$ million of personal income from wages and salaries.

None of the alternatives are projected to have any effect on income or employment opportunities in the sport or commercial fishing industries or those related economic sectors. Timber harvest activities may displace outfitter/guide use of portions of the Project Area until a few years after completion of harvest activities. Marketable recreational experience will change from a wildland experience to a roaded modified experience in areas affected by timber harvest activities. Because of the availability of alternative areas that could provide similar commercial opportunities, and because the Selected Alternative affects only some of the inventoried Recreation Places in the Project Area, no significant impact is expected on employment and income opportunities in the recreation and tourism industry.

Using the pond log values and logging costs from the fourth quarter of 1993, and normal (100 percent) profit and risk, the resulting estimated net stumpage value is positive for both sales. 


\section{Record of Decision}

The Selected Alternative, therefore, will be an economical offering under current and anticipated future market conditions. The estimated net stumpage value for each independent sale is shown in Table 1.

\section{Issue 5: How Will Timber Harvest and Road Building Activities Affect Wildlife Habitat?}

This issue includes concern over several wildlife species and habitat important to maintenance of wildlife populations.

The greatest direct effect to wildlife habitats will be the loss of old-growth habitat and change of forest habitat. Special emphasis habitats such as beach and estuary fringe are largely protected through timber harvest unit and road location. Old-growth habitat will be reduced by 14 percent.

All action alternatives, including the Selected Alternative, will decrease habitat capabilities for the Management Indicator Species (MIS) as much as 19 percent, but in most cases, less than 12 percent. Habitat capability is calculated utilizing models and does not necessarily indicate current or future populations, but rather is a means to measure potential effects.

The Project Area will remain a diverse and largely natural environment. In general, wildlife habitats will remain well connected by beach and estuary fringe, stream corridors and the myriad of muskegs, steep slopes, and areas not scheduled for harvest. Areas of undisturbed old growth that protect natural ecosystem processes and landscape scale wildlife species are maintained (see Figure R-1). Those areas of old growth that are not altered by the activities proposed in the Selected Alternative will retain their habitat characteristics. There are no large or medium Habitat Conservation Areas (HCAs) recommended for the Project Area by the Population Viability Committee to prevent wildlife habitat fragmentation (Final EIS, Chapter 4). Roads will not be maintained for vehicle travel following project completion, thus wildlife will not be affected by additional access (see RMOs in Appendix 3).

Issue 6: How would timber harvest, road building activities, and LTFs affect fish and shellfish habitat?

This issue addresses public concern for protecting streams that provide habitat to anadromous and resident fish and for protecting shellfish habitat in the marine environment.

Chapter 2 of the Final EIS concludes that the potential effects on fish and shellfish are minimal for all alternatives. All alternatives are designed and expected to meet the requirements of the Clean Water Act. Implementation of the Tongass Timber Reform Act (TTRA) requirements to provide a minimum 100 -foot buffer on Class I streams and Class II streams flowing directly into Class I streams will prevent direct stream channel impacts from timber harvest and road construction. Adherence to Best Management Practices (BMPs) outlined in the Soil and Water Conservation Handbook (FSH 2509.22) during timber harvest and road construction activities will minimize the potential for impacts on fish habitat.

No significant changes in stream temperature regimens, large woody debris recruitment, or stream nutrient cycles are expected as a result of the timber harvesting activities. Ripurian buffers as prescribed on the unit and road cards in Appendix C of the Final EIS and ROD Appendix 2 will minimize any adverse effects to water quality and fish habitat resulting from the authorized activities. Harvest units have been designed to minimize the potential for blowdown adjacent to streams.

Application of the LTF siting guidelines developed by the Alaska Timber Task Force will minimize the potential effects of LTFs on shellfish populations. Construction of drive-down type LTF facilities with a "no-splash" operation is authorized at Poison Cove and Goal Creek. 
Log transfer facility development is contingent upon approval of permits obtained from those agencies identified at the end of Final EIS Chapter 1. Should the permitting process result in significant changes to either the location or design of one or more of the log transfer facilities, such changes would be evaluated in an interdisciplinary manner according to NEPA and the results of the analysis documented. If such changes are significant, then my decision would be supplemented prior to development of the log transfer facility.

\section{Public Involvement}

Public involvement has been instrumental in identifying issues, formulating alternatives, and influencing this decision. Public scoping and involvement activities for the Ushk Bay project are listed in Appendix B of the Final EIS. A summary of the significant issues used to govern the interdisciplinary analysis was provided in the previous section of this document and in Chapter 1 of the Final EIS.

\section{Coordination with Other Agencies}

From the time scoping was initiated, meetings and other contacts with interested State and Federal agencies have occurred. Issues were discussed and information was exchanged. Appendix B of the Final EIS lists the meetings and chapter 6 identifies the agencies who were informed of, and/or involved in the planning process. The U.S. Army Corps of Engineers and U.S. Environmental Protection Agency were cooperators under provisions of the National Environmental Policy Act because of their role in issuing LTF permits.

\section{Alternatives}

Alternatives

Considered in Detail
The following six alternatives were considered in detail in the Final EIS. For a complete description of these alternatives, refer to chapter 2 of the Ushk Bay Final EIS. At the conclusion of this section, Table 2 lists the scheduled activities and major outputs for each of the six alternatives considered in detail along with the Selected Alternative.

Alternative A. The theme of this alternative is to propose no timber harvest or road construction in the Ushk Bay Project Area. A "No Action" alternative is required by NEPA, and this alternative serves as the benchmark by which effects of the action alternatives are measured. Implementation of TLMP to meet Forest Service goals would likely require timber harvest in the Project Area at some time in the foreseeable future, even if this "No Action" alternative was adopted in this decision.

Alternative B. The theme of this alternative is to consolidate timber harvest in areas accessible to proposed LTFs in Ushk Bay and Poison Cove, with no road connection between the two LTFs, and avoid harvest of timber in the area near Deep Bay and along Peril Strait.

Alternative $\mathrm{C}$. The theme of this alternative is to distribute timber harvest throughout the Project Area, with no road connections between the LTFs, but with selective harvest along Peril Strait to mitigate visual effects.

Alternative D. The theme of this alternative is to distribute a light timber harvest throughout the Project Area to facilitate a later entry to provide areas of different forest vegetation age classes within the Project Area. This alternative would include a road connection between 


\section{Record of Decision}

LTFs in Ushk Bay, Deep Bay, and Poison Cove for recreational use.

Alternative E. The theme of this alternative is maximizing availability of timber within the Project Area that meets TLMP standards and guidelines, while avoiding an LTF in Deep Bay

Table 2

Activities and Outputs (by Alternative)

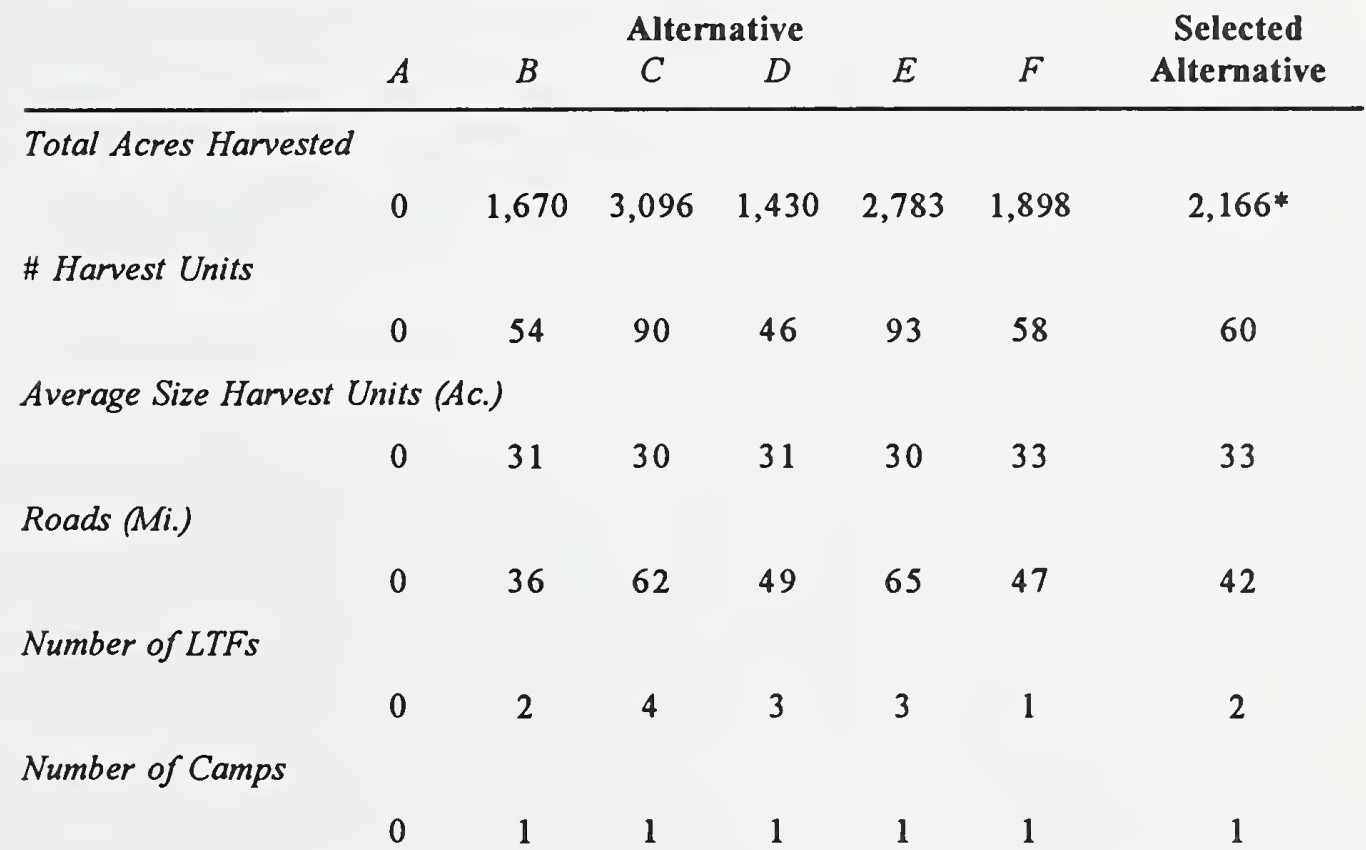

Volume - Net Sawlog plus Util. (MMBF)

$\begin{array}{lllllll}0 & 50.6 & 84.8 & 46.5 & 90.3 & 62.4 & 67.2^{*}\end{array}$

Employment (Number of Jobs)

$\begin{array}{lllllll}0 & 290 & 478 & 299 & 509 & 359 & 375\end{array}$

\section{Alternative \\ Eliminated from \\ Detailed \\ Consideration}

Environmentally
Preferred Alternative
An alternative which eliminated harvesting timber in the drainages tributary to Ushk Bay and which consolidated the harvest in other drainages of the Project Area was considered. The total recoverable volume from such an alternative would be so low that it would not be economically reasonable, therefore this alternative was eliminated from more detailed consideration. The alternative of avoiding timber harvest in the Ushk Bay drainages is embodied in the No Action alternative.

There is no single factor that can be used to determine which alternative is environmentally preferred. Maintaining the basic productivity of the land and the quality of lifestyle of the local residents are vitally important. 


\section{Record of Decision}

Based on the comparison of the alternatives shown in Table 2 and as displayed in chapter 2 and 4 of the Final EIS, Alternative A, the "No Action" alternative, would cause the least environmental disturbance. Among the action alternatives, Alternative B is the environmentally preferred alternative. This alternative has the second lowest level of acres proposed for harvest but has the fewest miles of road construction and associated stream crossings, and avoids Deep Bay and the visually sensitive area along Peril Strait.

The Selected Alternative is more environmentally preferred than Alternatives C, D, E, and F because of modifications incorporated in response to comments on the Draft EIS which mitigate potentially adverse environmental effects. The minimum number of LTFs is proposed to harvest the volume authorized, some units are dropped or unit boundaries adjusted to provide additional watershed and fisheries protection, Deep Bay is avoided, and selective harvest is prescribed for the visually sensitive area along Peril Strait.

\section{Mitigation}

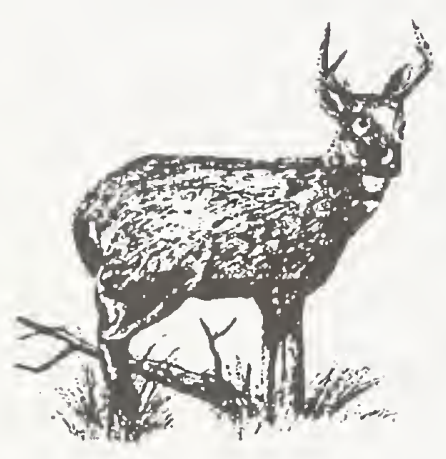

Applicable standards and guidelines of the Tongass Land Management Plan of 1979 (as amended), the Draft Tongass Land Management Plan Revision, the Alaska Regional Guide, and applicable Forest Service Manuals and Handbooks will minimize or negate many potentially adverse environmental effects from timber harvest and road construction. Water quality and fisheries habitat are protected through the application of Best Management Practices (BMPs) stated in the Soil and Water Conservation Handbook (FSH 2509.22) and the direction contained in the Aquatic Habitat Management Handbook (FSH 2609.24). In addition, the Tongass Timber Reform Act (TTRA) requires a minimum 100-foot buffer for all Class I streams and Class II streams directly flowing into Class I streams. The buffers and other stream protection measures adopted in this decision equal or exceed Tongass Timber Reform Act requirements.

Measures were applied in the development of the project alternatives, including the Selected Alternative, and in the location of the harvest units and road corridors to avoid, reduce, minimize or eliminate the adverse affects of timber harvest related actions. The Mitigation Measures section of Chapter 2 of the Final EIS discusses those measures common to all alternatives. Mitigation measures adopted include all practicable means to avoid or minimize the environmental harm from the proposed actions (40 CFR 1505.2(b)). The Final EIS includes Harvest Unit Cards and Road Cards (Appendix C) which incorporate site-specific mitigation. A more detailed description of the Selected Alternative mitigations is included below.

In the Selected Alternative, a number of measures to protect water quality and fish production have been included. Class III streams will be protected to prevent impact on downstream Class I or II streams as well as to prevent sedimentation and soil erosion. Unit 33, in the Poison Cove vicinity, has been dropped specifically to protect fish habitat and production.

Several units and sections of units have also been dropped in order to provide additional protection to water quality and fisheries habitat.

Mitigation measures and BMPs designed to protect water quality and fisheries habitat will likewise reduce impacts on forest soils. Soils with an extreme mass-wasting hazard have been avoided in the design of harvest units. Partial or full suspension of logs during yarding will be required in areas of units with high hazard soils. Trees will be felled away from v-notches and split yarding of v-notches will be required. In the Selected Alternative, a number of units and parts of units have been dropped in order to reduce impacts on forest soils. For example, Unit 81 and the western portion of Unit 12 were dropped due to their close proximity to a slide area. Settings in FEIS Units 75, 4, and 86 have been dropped because of the presence of vnotches and high hazard soils. Past experience indicates these measures are effective. In two 


\section{Record of Decision}

units ( 8 and 90 ), there will be areas in which only $30 \%$ of the existing volume will be harvested. Harvest will be done in such a way that the remaining standing timber is feathered, reducing the risk of blowdown and resulting impacts on soils, particularly in adjacent stands. Selective harvest and feathering have not been widely used in Southeast Alaska, but the location of the two areas, both topographically and in relation to adjacent stands, in conjunction with the layout directions and harvest method, should ensure that adverse effects on soils are minimized.

No logging camp or log transfer facility will be located in Ushk Bay. This is being done in response to the numerous comments from the public, as well as state and federal agencies about potential biological and sociological adverse impacts. This decision will avoid potential conflicts over recreational anchorages and subsistence crabbing in Ushk Bay.

Three areas along Peril Strait have been identified for uneven-aged management by the group selection method. Group selection cutting as an alternative to clearcutting was originally proposed in Alternative $\mathrm{C}$. In that alternative, there are six group selection areas in which approximately $25 \%$ of each area would be harvested in one to two acre groups. The primary reason for proposing this rather than clearcutting was to reduce the visual impact as viewed from boats in Peril Strait. The Selected Alternative goes even further in this respect. Here there are three group selection areas from which 15\% (Group III), 20\% (Group II) and 25\% (Group I) of the acres will be harvested. Harvest will be by helicopter, reducing associated impacts of road building on visual and other resources. Openings will be located and shaped so as to minimize their visibility from Peril Strait. The three areas will be managed on a 120- to 200-year rotation. The extended rotations are consistent with the direction in the 1985-86 Amendment to TLMP for Visual Management Class I areas in LUD III and IV VCUs.

Further measures to decrease impacts to the visual and recreation resources are dropping highly visible sections of units, and feathering the boundaries of some of the more visible units. See Unit Cards in Final EIS Appendix $\mathrm{C}$ for a more detailed description. Uneven aged management by group selection and unit boundary feathering have been done on a very limited scale in Southeast Alaska. Preliminary evidence is that these measures do reduce adverse effects to the visual and recreation resource.

To avoid adverse effects on wildlife habitat values, units were located outside of the beach and estuary fringe habitats wherever practicable, thereby reducing the potential to adversely impact high value habitats. Maintaining travel corridors for wildlife and retention of snags (where safe to do so) are measures individually identified on the road or unit cards in the Final EIS (Appendix C) which minimize adverse effects to wildlife. Additionally, all roads are to be closed following the completion of sale activities. Drainage structures may be removed if necessary for long-term resource protection and erosion control (waterbars, grass seeding) will be performed. Dropping all units in the vicinity of Deep Bay will reduce the acres of oldgrowth harvest and consequently reduce adverse effects to wildlife habitat. These measures have been used effectively in the past throughout Southeast Alaska.

To manage for subsistence resources, those measures which protect fish and game resources also generally serve to protect the availability of subsistence resources. For the Selected Alternative, as mentioned above, all roads will be closed following completion of sale activities. Past experience indicates that this is an effective measure to limit non-traditional use. The lack of a camp facility or LTF in Ushk Bay will also have the effect of limiting non-traditional use in this area, thereby protecting the availability of subsistence resources in Ushk Bay.

\section{Monitoring and Enforcement}

A monitoring program is the process by which the Forest Service can evaluate whether or not the resource management objectives of the Final EIS have been implemented as specified, and 


\section{National Forest Management Act}

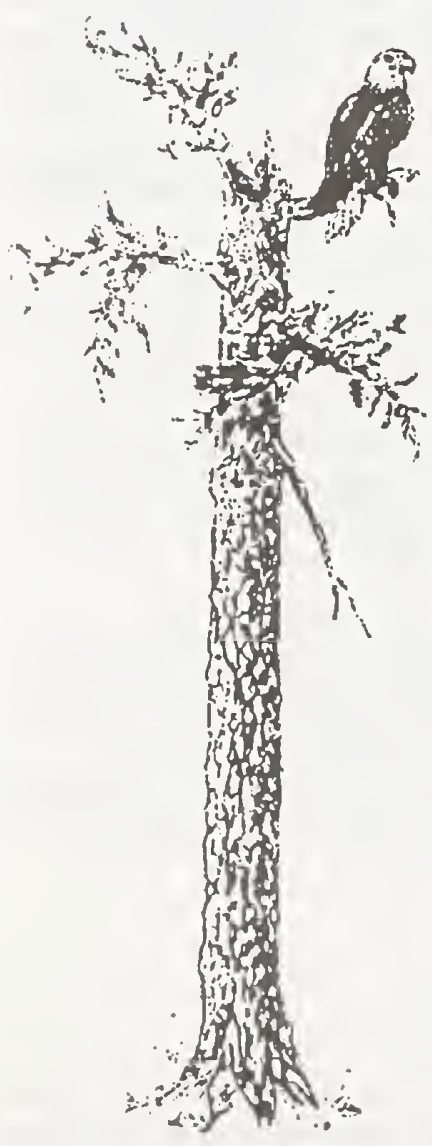

whether or not the steps identified for mitigating the environmental effects were effective. Three levels of monitoring are recognized. The first two levels, implementation monitoring and effectiveness monitoring, are feasible at the project level. The third level, validation monitoring, is conducted at the Forest wide level.

Applicable Monitoring requirements are specified in Appendix I of the Final EIS and ROD Appendix 5. For each monitoring item, an objective, desired result, method of measurement, threshold and corrective action are identified, along with the responsible staff. Monitoring activities may reveal results that deviate from planned effects, in which case corrective actions are prescribed (40 CFR 1505.2(c)).

The Chatham Area Forest Supervisor is responsible for ensuring that project implementation, mitigation, monitoring and enforcement is accomplished as specified.

\section{Findings Required by Law}

The National Forest Management Act (NFMA) requires specific determinations in this Record of Decision including consistency with existing Forest Plans and Regional Guides. It also requires a determination of clearcutting as the optimal method of harvesting and specific authorization of clearcuts over 100 acres in size.

Tongass Land Management Plan and Alaska Regional Guide. This decision is consistent with the Alaska Regional Guide and the Tongass Land Management Plan of 1979, as amended. I have reviewed the management direction and the schedule of activities for the VCUs included in the Selected Alternative, and find the Selected Alternative to be consistent with these elements. The areas of undisturbed old-growth wildlife habitat maintained in this alternative exceed the standards for retention established in TLMP.

Although not required, the activities authorized in this decision are consistent to the extent practicable with the proposed standards and guidelines and management prescriptions of the Proposed Revised Forest Plan.

Clearcutting as the Optimal Method of Harvesting. The Alaska Regional Guide established silvicultural and management standards for western hemlock - Sitka spruce forest type (Alaska Regional Guide, page 3-18). Even-aged management in the form of clearcutting is, according to the Regional Guide, to be used where the management objective is to meet timber production objectives established in the Forest Plan, where there is a risk of dwarf mistletoe reinfection and where risk of windthrow is determined to be high. Dwarf mistletoe is somewhat of a problem in the Ushk Bay Project Area, particularly on the north shore of Ushk Bay. All of the harvest units being proposed in the Selected Alternative have a high risk of windthrow. All units in the Selected Alternative, except the three Groups and the two units (8 and 90) with areas of selective harvest and feathering, both discussed in the Mitigation section, are prescribed for clearcut harvest. Clearcutting of the proposed harvest units will meet the objective of maintaining fast-growing, mistletoe-free stands of mixed species and is the optimum method of harvesting, considering the following factors referenced in the Alaska Regional Guide:

The thin bark and shallow roots of hemlock and spruce make them particularly susceptible to logging injury, which leads to decay. Losses from decay fungi are high, especially in the oldgrowth forests of Alaska. Conversion from old to young growth by clearcutting has the greatest potential for reducing decay. 


\section{Record of Decision}

Hemlock dwarf mistletoe, Arcenthobium tsugense, an important disease of western hemlock can best be controlled by clearcutting. Elimination of residual overstory trees infected with dwarf mistletoe prevents infection of western hemlock in the new stand.

Exposure to the sun raises soil temperature, which speeds decomposition, thereby improving the productivity of northern sites.

Clearcutting favors regeneration of Sitka spruce by destroying advance hemlock regeneration and by creating more favorable conditions for post-logging reproduction of spruce.

Risk of blowdown in residual stands is eliminated. The chance of blowdown along cutting boundaries is increased but can be reduced through proper design of cutting units.

Natural seed fall is generally adequate for regeneration and most young stands are dense.

Logging costs are lower than with other systems.

Clearcuts Over 100 Acres in Size. Unit 13 is 121 acres and is the only unit that exceeds 100 acres. Unit 13 exceeds 100 acres because of natural and biological hazards to residual trees and surrounding stands and logging system and transportation system requirements as allowed for in the Alaska Regional Guide. This unit was clearly displayed for comment during the 75day review of the Draft EIS. This 75-day public comment period meets the requirements of the Alaska Regional Guide for approval of units over 100 acres. Based on public review and the reasons listed for the unit being greater than 100 acres above, this unit is authorized for harvest as designed.

\section{Tongass Timber Reform Act}

Harvest units were designed and will be located to maintain a minimum 100 -foot buffer zone for all Class I streams and Class II streams that flow directly into Class I streams as required in Section 103 of the TTRA. The actual widths of these buffer strips will often be greater than the 100-foot minimum. The design and implementation direction for the Selected Alternative incorporate BMPs for protection of all stream classes.

Per Section 301 of the TTRA, the Ushk Bay Project was planned, management requirements were applied, and environmental analysis procedures were followed consistent with procedures for independent National Forest timber sales. Section 301(c)(2) of the TTRA modified the Alaska Pulp Corporation (APC) and Ketchikan Pulp Company contracts to require proportional harvest of Volume Classes 6 and 7 timber. The statute does not impose proportional harvest as a requirement on independent sales. The APC long-term contract termination eliminates proportional harvest as an applicable statutory requirement for the Ushk Bay Selected Alternative that will be implemented through independent timber sale contracts.

However, analysis of proportional harvest of Volume Classes 6 and 7 was performed using the procedures in Forest Service Sale Preparation Handbook 2409.18, Region 10 Supplement No. 2409.18-93-3 for the Selected Alternative. It was determined that upon completion of the Selected Alternative's harvest, proportionality consistent with FSH 2409.18 direction for Management Areas C39 and C40 will result. Refer to ROD Appendix 4 for the analysis of the proportion of Volume Classes 6 and 7 planned for harvest with the Selected Alternative. Forest Service methodology used to implement section 301(c)(2) has been challenged in court, in Wildlife Society et al. v. Barton, J93-001 CIV (D. Alaska). An alternative methodology is being evaluated but is not available at this time. 


\section{Record of Decision}

\section{Endangered Species}

Act

\author{
Bald Eagle Protection
} Act

\section{Clean Water Act}

\section{National Historic Preservation Act}

Federal Cave Resource Protection Act of 1988

Subsistence Finding: ANILCA Section 810
The Selected Alternative will not have a direct, indirect, or cumulative effect on any threatened, endangered or sensitive species in the Ushk Bay Project Area. A biological assessment is included in Appendix $\mathrm{J}$ of the Final EIS. I have determined that this action will not have any adverse impacts on any threatened or endangered species.

The Selected Alternative will not have a direct, indirect, or cumulative effect on any bald eagle.

Management activities inconsistent with current bald eagle use within 330 feet of an eagle nest tree are restricted by a 1990 Memorandum of Understanding (MOU) between the Forest Service and the U. S. Fish and Wildlife Service to facilitate compliance with the Bald Eagle Protection Act. Three variances from the MOU have been obtained for implementation of the Selected Alternative for construction of roads within 330 feet of known eagle nest trees. A variance has also been issued for conducting helicopter operations within 1/4 mile of eagle nests and documentation is included in Appendix $\mathrm{N}$ of the Final EIS.

The location of harvest units and roads for the Selected Alternative was guided by standards, guidelines, and direction contained in the current TLMP, the proposed TLMP Revision, the Alaska Regional Guide, and applicable Forest Service manuals and handbooks. The unit cards and road cards (Appendix $\mathrm{C}$ in the Final EIS and ROD Appendix 2) contain specific details on practices prescribed to prevent or reduce non-point sediment sources. Implementation with site specific application and monitoring of approved BMPs, will comply with applicable State Water Quality Standards Regulations. These regulations provide for variances from antidegradation requirements and water quality criteria. The harvest and road building operators will be responsible for compliance, including obtaining any variance required by the State, and will be monitored for compliance by the Forest Service. The Forest Service expects the Ushk Bay Project activities to fully qualify for any variance required by the State, according to the criteria in $18 \mathrm{AAC} 70.015$.

A monitoring plan to detect and evaluate possible effects of bark accumulations, oil sheens, and surface runoff will be implemented as a part of the permitting process for $\log$ transfer facilities (BMP 14.4, FSH 2509.22).

Cultural resource surveys have been conducted in the Project Area. The State Historic Preservation Officer has been consulted, and the provisions of 36 CFR part 800 have been complied with. The Forest Service timber sale contract contains enforceable measures for protecting any undiscovered cultural resource that might be encountered during sale operations. All ground-disturbing activities associated with this action have received cultural resource clearance by the State Historic Preservation Officer. Based on surveys conducted by professional archaeologists in the project area, I have determined, there will be no significant effects on cultural resources.

The actions in the Selected Alternative will not have a direct, indirect, or cumulative effect on any significant cave in the Ushk Bay Project Area. No cave resources have been documented in the Project Area and field work done for this analysis failed to discover any caves (Final EIS, Chapter 3).

A subsistence evaluation was conducted for the six alternatives considered in detail in accordance with ANILCA Section 810. An open house followed by an ANILCA Section 810 hearing was held in Sitka on July 19, 1993.

The evaluation of comments from the public, subsistence hearing testimony, and additional 


\section{Record of Decision}

analysis, indicates the following:

The potential foreseeable effects from the action alternatives in the Ushk Bay Project Area do not indicate a significant possibility of a significant restriction of subsistence uses for brown bear, furbearers, marine mammals, waterfowl, and other foods such as berries and roots.

There is a significant possibility of a significant restriction of subsistence use of Sitka blacktailed deer in the Project Area, regardless of which alternative is implemented, including the "No Action" alternative. This possibility of restriction of subsistence use is for the communities of Haines, Petersburg, Sitka, and Wrangell.

Among these communities, there is sufficient habitat capability in Wildlife Analysis Areas where residents successfully harvest deer to meet subsistence needs of all communities in the foreseeable future except for Sitka.

There is also a significant possibility of a significant restriction of subsistence use of fish and shellfish, based on changes in access during the period of active timber harvest, for alternatives that include an LTF or logging camp in Ushk Bay.

Based on a review of the subsistence hearing testimony and the analysis conducted in the Final EIS, it is apparent that all of the action alternatives involve some potential to impact subsistence uses. There is no alternative that would meet TLMP direction and yet avoid a significant possibility of a subsistence restriction somewhere in the Forest. Therefore, based on the analysis of the information presented in the Final EIS, it is my determination these actions are necessary, consistent with sound management of public lands.

The amount of public land involved to implement the Selected Alternative is (considering sound multiple-use management of public lands) the minimum necessary. Conversion of oldgrowth forest into second-growth forest affects habitat capability for deer and other old-growth dependent species wherever it occurs on the Tongass National Forest, and habitat is used forestwide by such species.

The entire Tongass National Forest is used by one or more rural communities for subsistence purposes for deer hunting (TRUCS, Forest Service 1990b). The areas of most subsistence use are the areas adjacent to existing road systems, beaches and the areas in close proximity to the communities. Much effort was taken to protect the highest value subsistence areas. For example, beach fringe is one of the highest use subsistence areas and three percent or less will be impacted with the Selected Alternative.

It is not possible to lessen harvest in one area and concentrate it in another without impacting one or more rural communities' important subsistence use areas. In addition, harvestable populations of game species could not be maintained in a natural distribution across the Forest if harvest was concentrated in specific areas. A well-distributed population of species is also required by the Forest Service regulations implementing the NFMA. Therefore; I conclude the acres scheduled for harvest in the Selected Alternative meet sound multiple-use management of public lands, and involve the minimum amount of public land used for subsistence. Furthermore, the Selected Alternative resolves resource concerns reflected in the public issues associated with this EIS.

Impacts on subsistence have been minimized through the development of the individual harvest units and road corridors, and through the formulation of the alternatives. Mitigation measures applicable to all resources including subsistence are described in this ROD. It is my determination that reasonable measures to minimize impacts on subsistence have been adopted to the maximum extent practicable while still meeting the purpose and need for this project.

The Selected Alternative reflects special efforts by the Forest Service to minimize the effects on resources used for subsistence by those rural communities that would be most likely to receive the highest priority in the event of an ANILCA section 804 "Tier II" restriction. 


\section{Record of Decision}

\section{Executive Orders \\ 11988 and 11990}

Coastal Zone

Management Act

\section{Federal and State \\ Permits}

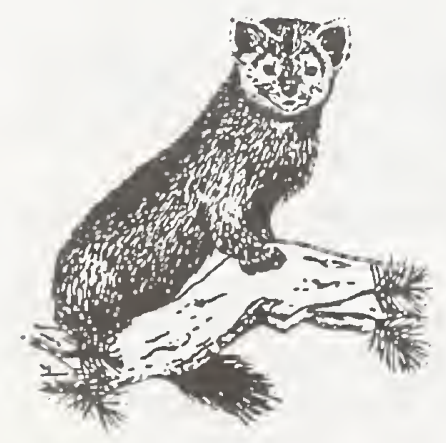

Executive Order 11988 directs Federal agencies to take action to avoid, to the extent possible, the long and short-term adverse impacts associated with the occupancy and modification of floodplains. The numerous streams in the Ushk Bay Project Area makes it impossible to avoid all floodplains during timber harvest and road construction. The design of the Selected Alternative and the application of Best Management Practices combine to minimize adverse impacts on floodplains.

Executive Order 11990 requires Federal agencies to avoid to the extent possible the long and short-term adverse impacts associated with the destruction or modification of wetlands. The Selected Alternative avoids most identified wetlands, however many small wetlands or muskegs occur as inclusions within forested areas. These areas may be altered by timber harvest or road construction, however techniques and practices required by the Forest Service serve to maintain the wetland attributes. It is estimated there will be no net loss of wetlands with any of the alternatives. Soil moisture regimes and vegetation on some wetlands may be altered in some cases; however, these altered acres would still be classified as wetlands and function as wetlands in the ecosystem.

The Coastal Zone Management Act of 1976 (as amended) excludes Federal lands from the Coastal Zone. However, the act requires that when Federal agencies conduct activity or undertake development affecting the coastal zone, they be consistent to the maximum extent practicable with the approved State Coastal Management Program.

The Alaska Coastal Management Plan incorporated the Alaska Forest Resources and Practices Act of 1979 (as revised) as the applied standards and guidelines for timber harvesting and processing. The Forest Service Standards and Guidelines and Mitigation Measures described in Chapter 2 of the Final EIS are fully consistent with the State Standards.

Based on the analysis in the Final EIS, review of the Alaska Forest Practices Act, and comments from the City of Sitka and State agencies on the DEIS, the action and activities are consistent to the maximum degree practicable with the Alaska Coastal Management Plan.

Federal and State permits necessary to implement the authorized activities are listed at the end of Chapter 1 of the Final EIS. These permits are results of the National Policy and Laws briefly described above.

\section{Implementation of This Decision}

Implementation of this decision may occur no sooner than 50 days from the date of publication of the notice of the decision in the Juneau Empire, the official newspaper of record.

This project will be implemented in two or more timber sales in accordance with Forest Service Manual and Handbook direction for Timber Sale Project Implementation in FSM 2432.3 Gate 3 and FSH 2409.18 Sale Prep. This direction provides a bridge between project planning and implementation, and will ensure execution of the actions, environmental standards, and mitigations approved by this decision, and compliance with TTRA and other laws.

Implementation of all activities authorized by this Record of Decision will be monitored to ensure that they are carried out as planned and described in the Final EIS, ROD, and planned unit and road cards, unless they are modified consistent with direction in FSM 2432.3 and FSH 2409.18.

Appendix $\mathrm{C}$ of the Final EIS and ROD Appendix 2 contain the planned unit and road cards. These cards are an integral part of this decision because they document the specific resource 


\section{Record of Decision}

concerns, management objectives, and mitigation measures to govern the layout of the harvest units and construction of roads. These cards will be used during the implementation process to ensure that all aspects of the project are implemented within applicable standards and guidelines and that resource impacts will not be greater than those described in the EIS. Similar cards will be used to document any changes to the planned layout as the actual layout and harvest of the units occurs with project implementation. The implementation record for this project will display each harvest unit, transportation facility, and other project components as actually implemented, any proposed changes to the design, location, standards, and guidelines, or other mitigation measures for the project, and the decisions on the proposed changes.

Any proposed changes to authorized project actions will be fully subject to an interdisciplinary review process and the documentation, public involvement, and other requirements of the National Environmental Policy Act (NEPA), the National Forest Management Act of 1976 (NFMA), section 810 of the Alaska National Interest Lands Conservation Act (ANILCA), the Tongass Timber Reform Act (TTRA), the Coastal Zone Management Act (CZMA), and other laws concerning proposed actions.

The Forest Supervisor will determine whether further NEPA, ANILCA, TTRA or other documentation or disclosure, opportunity for public involvement, or other action is necessary before proceeding with any action that deviates from the planned activity. Connected or interrelated proposed changes regarding particular areas or specific activities will be considered together in making this determination. Cumulative impacts will be considered.

In determining whether and what kind of further NEPA action is required, the Forest Supervisor will consider the criteria for whether to supplement an existing Environmental Impact Statement in 40 CFR 1502.9(c), and in particular, whether the proposed change is a substantial change to the selected alternative as planned and already approved, and whether the change is relevant to environmental concerns. As part of this determination, the Supervisor will review whether the change would as an initial proposed action be categorically excluded from preparation of an Environmental Assessment (EA) or EIS on the basis of criteria in FSH 1901.15, Chapter 30. A determination that correction, supplementation, or revision of the EIS or ROD is not required will be documented in a project implementation file memorandum. FSH 1909.15, Sections 18.1 adn 18.2.

Many minor changes to harvest units, transportation facilities, or other project components may be categorically excluded from documentation in an EA or EIS or otherwise not require an existing EIS or ROD to be corrected, supplemented, or revised. Besides documentation in a project implementation file memorandum, these minor changes may still require appropriate scoping, environmental analysis, documentation in a Decision Memo, and public notice to comply with FSH 1909.15. 


\title{
Right to Appeal
}

This decision is subject to administrative appeal. Organizations or members of the general public may appeal this decision according to Title 36 Code of Federal Regulations (CFR) 215. The appeal must be filed within 45 calendar days of the date that legal notification of this decision is published in the Juneau Empire, the official newspaper of record. The Notice of Appeal must be filed with:

\author{
Phil Janik \\ Regional Forester \\ USDA Forest Service, Region 10 \\ P.O. Box 021628 \\ Juneau, AK 99802-1628
}

It is the responsibility of those who appeal a decision to provide the Regional Forester sufficient narrative evidence and argument to show why the decision by the Forest Supervisor should be changed or reversed. Copies of 36 CFR 215 are available from any Forest Service Office.

The first timber sale is planned to be made available as part of the current timber supply in September 1995. Implementation of this action can begin 5 business days from the close of the 45 day appeal filing period.

An appeal of this decision would evoke a stay of implementation of the Selected Alternative until fifteen days after the appeal decision.

Contact Person

For additional information concerning the specific activities authorized with this decision contact the Ushk Bay Planning team:

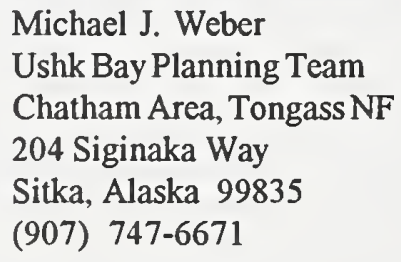

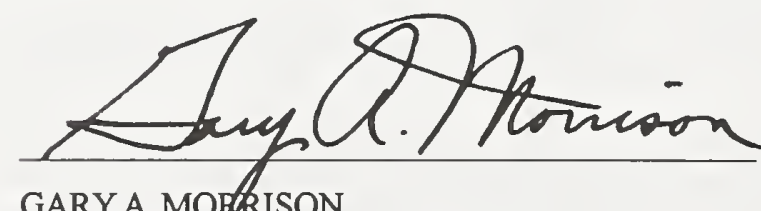

GARY A. MOHRISON

Forest Supervisor, Chatham Area

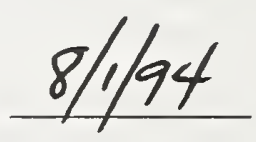

Date 


\section{Legend}

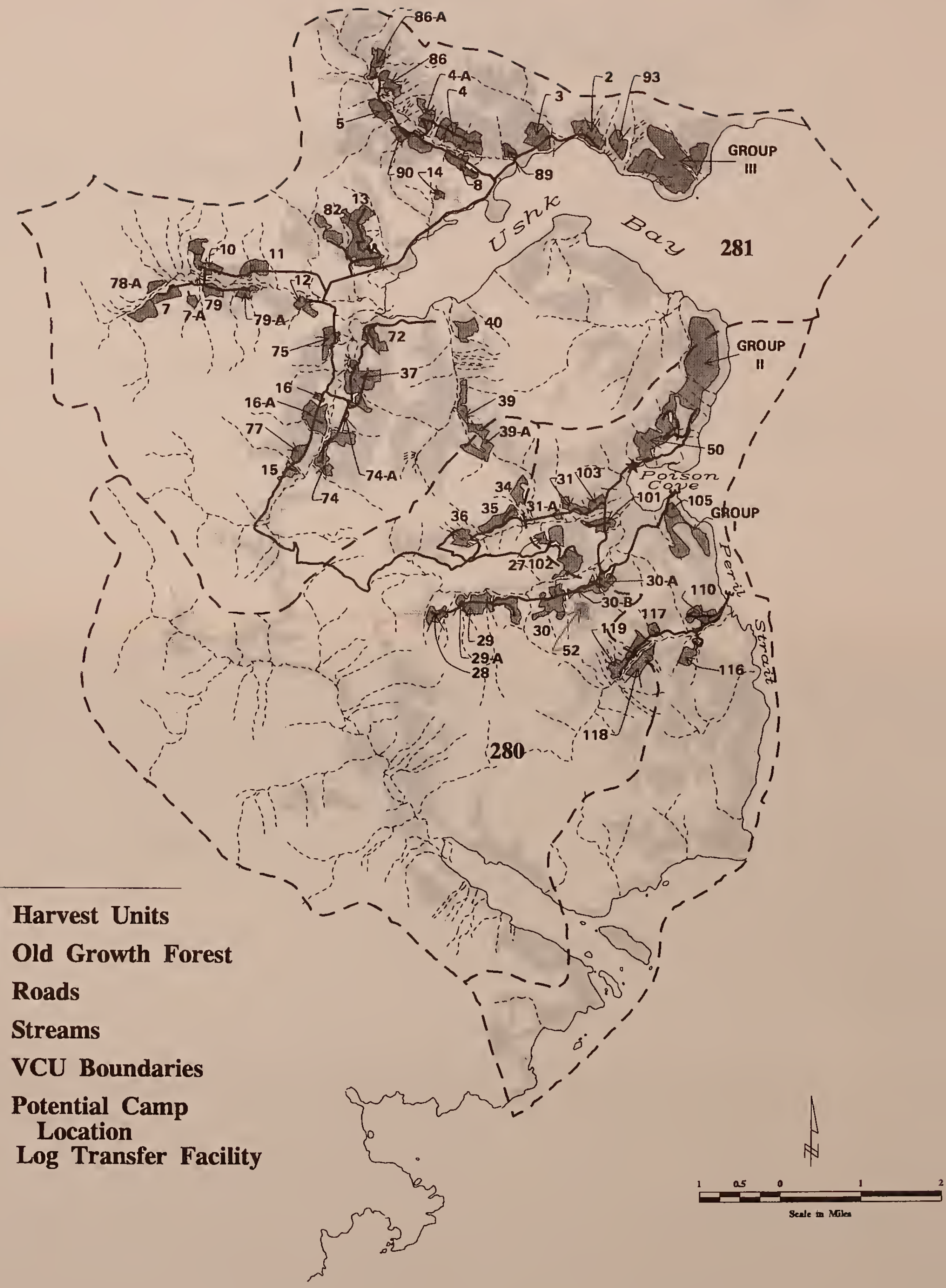





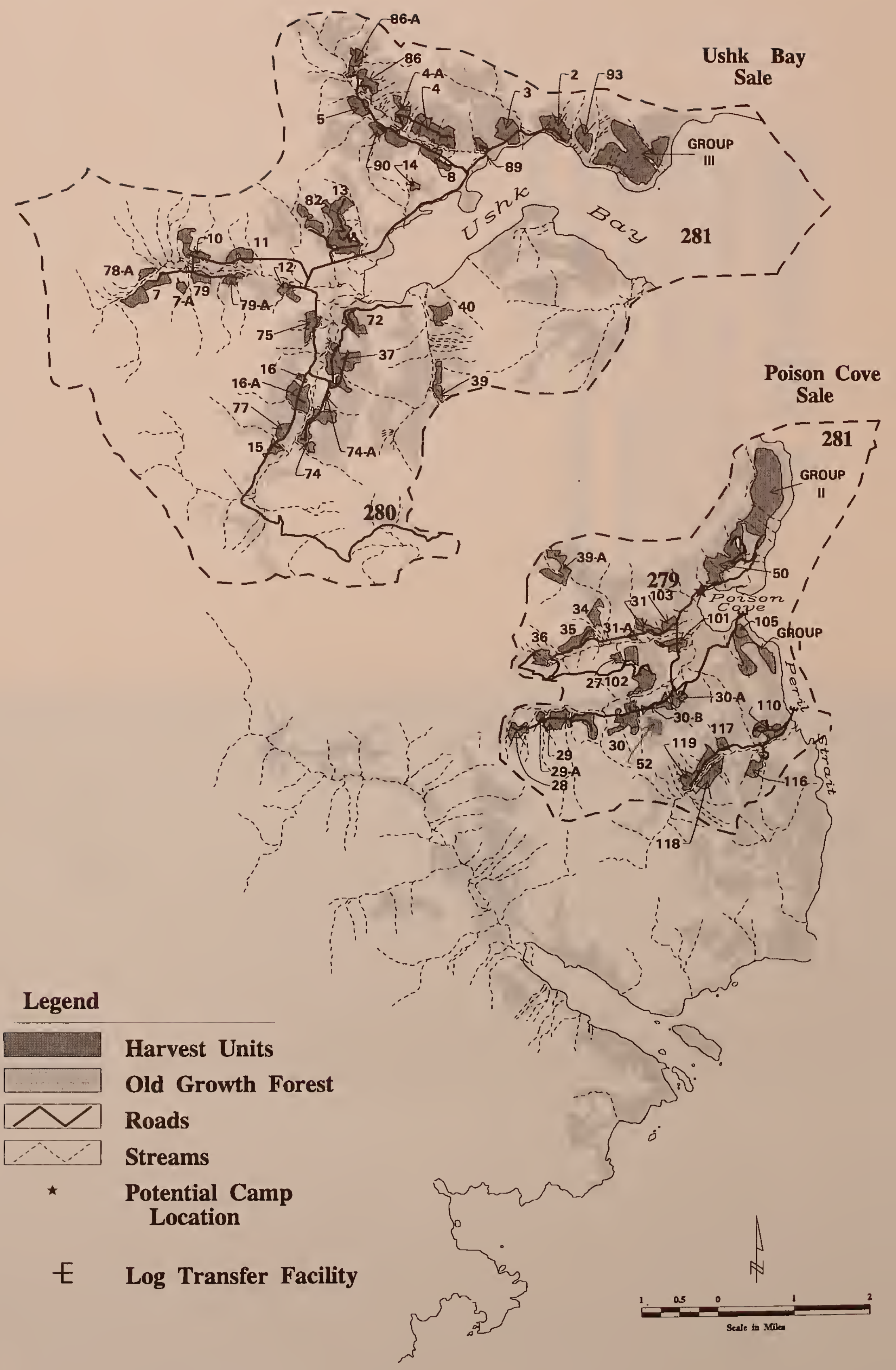

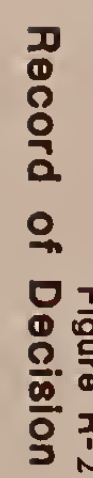





\section{Appendix 1}

Harvest Units Specific to the Selected Alternative; Post-harvest Silvicultural Treatments; Enhancement Opportunities 

Table $7-1 \mathrm{~A}$

Poison Cove Selected Alternative Volumes

\begin{tabular}{|c|c|c|c|c|c|c|c|c|c|}
\hline VCU & $\begin{array}{c}\text { Harvest } \\
\text { Unit }\end{array}$ & $\begin{array}{c}\text { Live } \\
\text { Skyline }\end{array}$ & Highlead & Helicopter & $\begin{array}{l}\text { Running } \\
\text { Skyline }\end{array}$ & Slackline & Shovel & $\begin{array}{c}\text { Total } \\
\text { Acres }\end{array}$ & $\begin{array}{c}\text { Total } \\
\text { Volume } \\
\text { (MBF) }\end{array}$ \\
\hline \multirow[t]{14}{*}{279} & 27 & 32.10 & & & & & & 32.10 & 813 \\
\hline & $30 \mathrm{~A}$ & & & & 2.50 & 17.80 & & 20.30 & 683 \\
\hline & 31 & & & & 9.30 & 12.40 & & 21.70 & 612 \\
\hline & $31 \mathrm{~A}$ & & & & 5.30 & & & 5.30 & 118 \\
\hline & 50 & & & & 4.40 & 81.10 & & 85.50 & 3157 \\
\hline & 101 & & & & & & 27.10 & 27.10 & 1024 \\
\hline & 102 & 18.10 & & 6.00 & & 16.10 & & 40.20 & 1482 \\
\hline & 103 & & & & 17.80 & & & 17.80 & 537 \\
\hline & 105 & & & & 9.10 & 2.20 & & 11.30 & 382 \\
\hline & 110 & & 30.40 & & 13.00 & & & 43.40 & 1119 \\
\hline & 116 & & 24.90 & & & & & 24.90 & 378 \\
\hline & 117 & & 10.40 & & & & & 10.40 & 301 \\
\hline & Gr 1 & & & 16.00 & & & & $16.0^{*}$ & 500 \\
\hline & Gr 2 & & & 53.00 & & & & $53.0^{*}$ & 1417 \\
\hline 279 & Totals & 50.20 & 65.70 & 75.00 & 61.40 & 129.60 & 27.10 & 409.00 & 12523 \\
\hline \multirow[t]{11}{*}{280} & 28 & 24.00 & & & & & & 24.00 & 591 \\
\hline & 29 & & 11.70 & & 40.80 & $22: 0$ & & 74.60 & 2347 \\
\hline & $29 \mathrm{~A}$ & & & & 7.40 & & & 7.40 & 247 \\
\hline & 30 & 8.90 & 5.90 & 20.50 & 3.70 & 20.70 & & 59.70 & 1456 \\
\hline & $30 \mathrm{~B}$ & & & & 19.40 & & & 19.40 & 473 \\
\hline & 34 & & & 22.70 & & & & 22.70 & 620 \\
\hline & 35 & & & & 29.40 & 10.10 & & 39.50 & 1424 \\
\hline & 36 & 23.30 & & & & & & 23.30 & 708 \\
\hline & 52 & & & 19.90 & & & & 19.90 & 480 \\
\hline & 118 & & & & & 34.50 & & 34.50 & 1337 \\
\hline & 119 & & & & & 48.30 & & 48.30 & 1524 \\
\hline 280 & Totals & 56.20 & 17.60 & 63.10 & 100.70 & 135.70 & & 373.30 & 11207 \\
\hline 281 & $39 \mathrm{~A}$ & & & 47.00 & & & & 47.00 & 2044 \\
\hline 281 & Totals & & & 47.00 & & & & 47.00 & 2044 \\
\hline \multicolumn{2}{|c|}{ Poison Cove Unit Totals } & 106.40 & 84.30 & 185.10 & 162.10 & 265.30 & 27.10 & 829.30 & 25774 \\
\hline \multicolumn{2}{|c|}{ Inter-unit ROW } & & & & & & & 65.40 & 1635 \\
\hline \multicolumn{4}{|c|}{ Poison Cove Selected Alternative Totals } & & & & & 894.70 & 27409 \\
\hline \multicolumn{10}{|c|}{ * Actual Harvest Acres } \\
\hline \multicolumn{10}{|c|}{ Note: Volumes are Net Sawlog plus Utility } \\
\hline
\end{tabular}




\begin{tabular}{|c|c|c|c|c|c|c|c|c|c|}
\hline Ushk Bay & Selected Al & Iternative $\mathrm{V}$ & olumes & & & & & & \\
\hline VCU & Harvest Unit & Live Skyline & Highlead & Helicopter & $\begin{array}{l}\text { Running } \\
\text { Skyline }\end{array}$ & Slackline & Shovel & Total Acres & $\begin{array}{l}\text { Total } \\
\text { Volume } \\
\text { (MBF) }\end{array}$ \\
\hline \multirow[t]{34}{*}{281} & 2 & 9.5 & & & 40.2 & & & 49.7 & 1474 \\
\hline & 3 & & & & & 43 & 7.8 & 50.8 & 1733 \\
\hline & 4 & 8.5 & & & 37.6 & 39.9 & & 86 & 4090 \\
\hline & $4 \mathrm{~A}$ & & 10.8 & 12.3 & & & & 23.1 & 1099 \\
\hline & 5 & & & & 29.3 & & & 29.3 & 604 \\
\hline & 7 & 23.8 & & 32.3 & & & & 56.1 & 1172 \\
\hline & $7 \mathrm{~A}$ & & & & 9.5 & & & 9.5 & 141 \\
\hline & 8 & & & & 27.3 & & 2.2 & $29.5^{*}$ & 794 \\
\hline & 10 & & & 23.1 & 21 & & & 44.1 & 1211 \\
\hline & 11 & 20.8 & & & 6.9 & & 4 & 31.7 & 1090 \\
\hline & 12 & 22.1 & & & & & & 22.1 & 721 \\
\hline & 13 & 46.7 & 9.7 & 13.1 & 36 & 15.6 & & 121.1 & 3553 \\
\hline & 14 & & & 7 & . & & & 7 & 73 \\
\hline & 15 & & & & 5.3 & & 10.3 & 15.6 & 594 \\
\hline & 16 & & & & & 5.6 & & 5.6 & 118 \\
\hline & $16 \mathrm{~A}$ & & & & 8.3 & 30.8 & 14.9 & 54 & 2297 \\
\hline & 37 & 63.4 & & & 7.3 & & 15.1 & 85.8 & 2503 \\
\hline & 39 & & & 31.2 & & & & 31.2 & 1362 \\
\hline & 40 & & & 31.6 & & & & 31.6 & 881 \\
\hline & 72 & 3.5 & & & 9.9 & 20.4 & & 33.8 & 1422 \\
\hline & 74 & 33.9 & & & & & 22.9 & 56.8 & 1318 \\
\hline & $74 \mathrm{~A}$ & 2.1 & & & & & & 2.1 & 44 \\
\hline & 75 & 30.5 & & & & & & 30.5 & 912 \\
\hline & 77 & 16.8 & & & & & & 16.8 & 683 \\
\hline & $78 \mathrm{~A}$ & & 11.1 & & & & & 11.1 & 431 \\
\hline & 79 & & & & 8.1 & & 12.1 & 20.2 & 720 \\
\hline & $79 \mathrm{~A}$ & & & & 14.8 & & & 14.8 & 571 \\
\hline & 82 & & & 12.8 & 16.2 & & & 29 & 1031 \\
\hline & 86 & & & & 21 & & & 21 & 905 \\
\hline & $86 \mathrm{~A}$ & & & 20.6 & 5 & & 1.3 & 26.9 & 672 \\
\hline & 89 & & & & 12.6 & & & 12.6 & 581 \\
\hline & 90 & & & & 42.6 & & & $42.6^{*}$ & 1406 \\
\hline & 93 & & & & 14.7 & 17.1 & & 31.8 & 460 \\
\hline & Gr 3 & & & 38 & & & & $38.0^{*}$ & 1137 \\
\hline \multicolumn{2}{|c|}{ Ushk Bay Unit Totals } & 281.6 & 31.6 & 222 & 373.6 & 172.4 & 90.6 & 1171.8 & 37803 \\
\hline \multicolumn{2}{|c|}{ Inter-unit ROW } & & & & & & & 99.6 & 1992 \\
\hline \multicolumn{4}{|c|}{ Ushk Bay Selected Alternative Totals } & & & & & 1271.4 & 39795 \\
\hline \multicolumn{10}{|c|}{ - Actual Harvest Acres } \\
\hline \multicolumn{10}{|c|}{ Note: Volumes are Net Sawlog plus Utility } \\
\hline Source: $\mathrm{Sm}$ & ith, 1994 & & & & & & & & \\
\hline
\end{tabular}




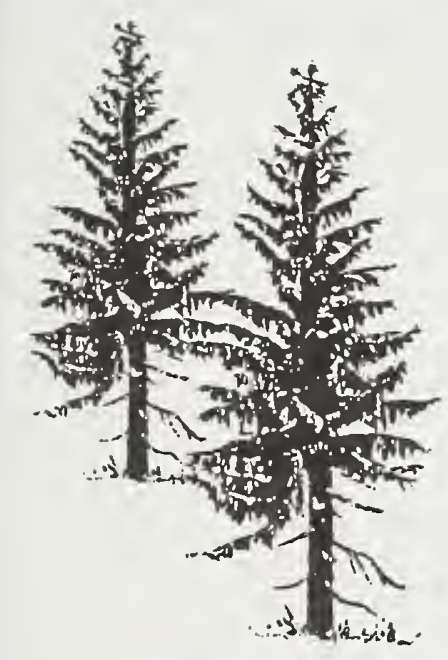

\section{Post-Harvest Silvicultural Treatments}

Post harvest silvicultural treatments that will occur in the Ushk Bay Project Area after timber harvest include hand planting and precommercial thinning of proposed harvest units. Table 12 displays a list of Selected Alternative units that may be hand planted. Actual planting acres will be determined by regeneration survey results and will likely include parts of units rather than entire units. Alaska yellow cedar and Sitka spruce will be planted in order to maintain current species composition and wildlife habitat diversity, and to meet NFMA requriements for adequate stocking.

Table 1-2

Selected Alternative - Potential Hand Planting

\begin{tabular}{lrll}
\hline VCU & Total Acres & Species to Plant & Harvest Units \\
\hline 281 & 50 & Alaska cedar & 2 \\
& 100 & & 7,10 \\
& 30 & & 8 \\
& 54 & Sitka spruce & 11,12 \\
& 78 & & $39,39 \mathrm{~A}$ \\
& 50 & & 72,77 \\
Total & 266 & & \\
\hline Source: Smith, 1994 & & &
\end{tabular}


Precommercial thinning to improve stand vigor and timber production is proposed for the Selected Alternative units in Table 1-3. These units will be evaluated for thinning needs 10 to 12 years following harvest.

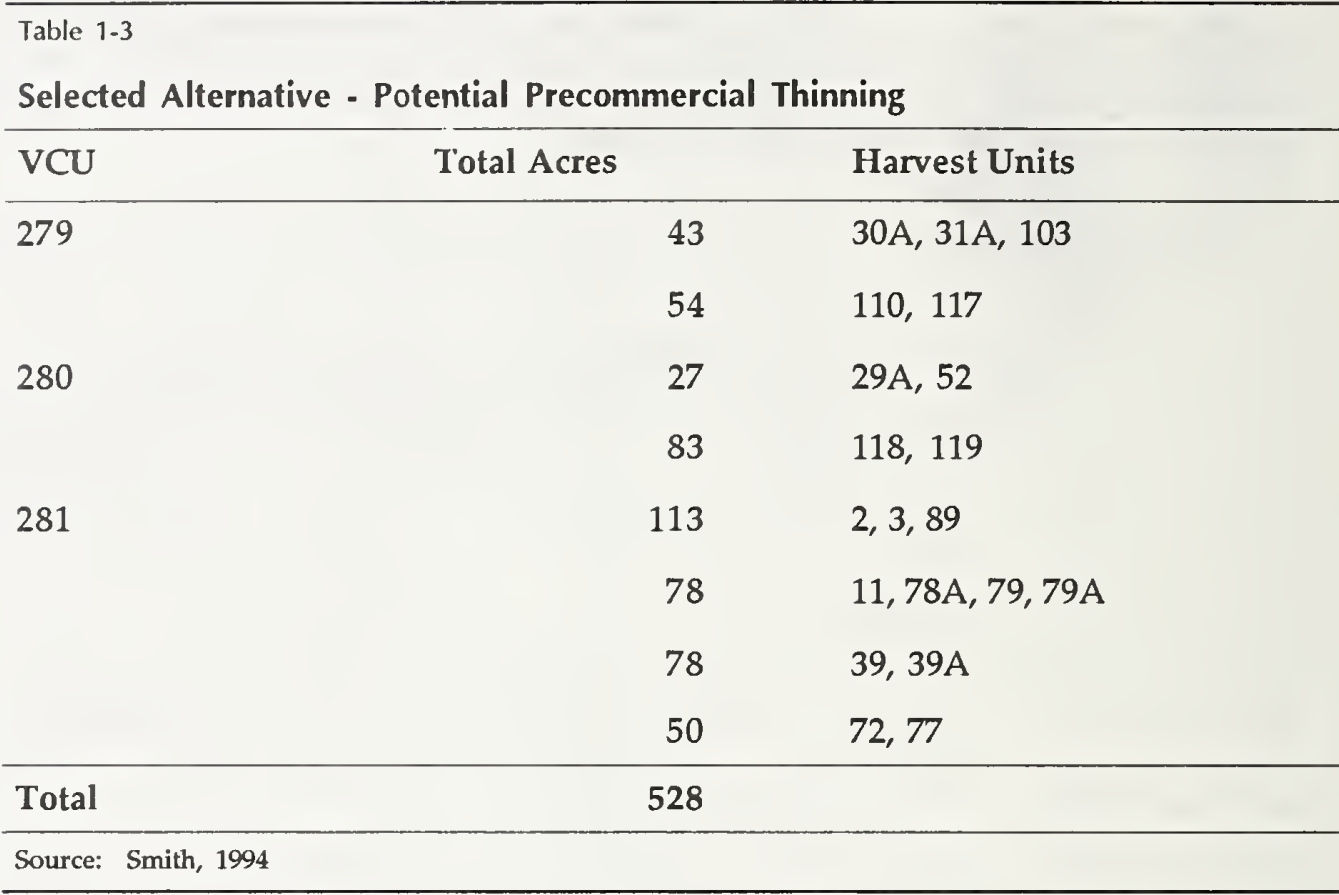




\section{Appendix 2 Unit Cards Not Included in the Final EIS}





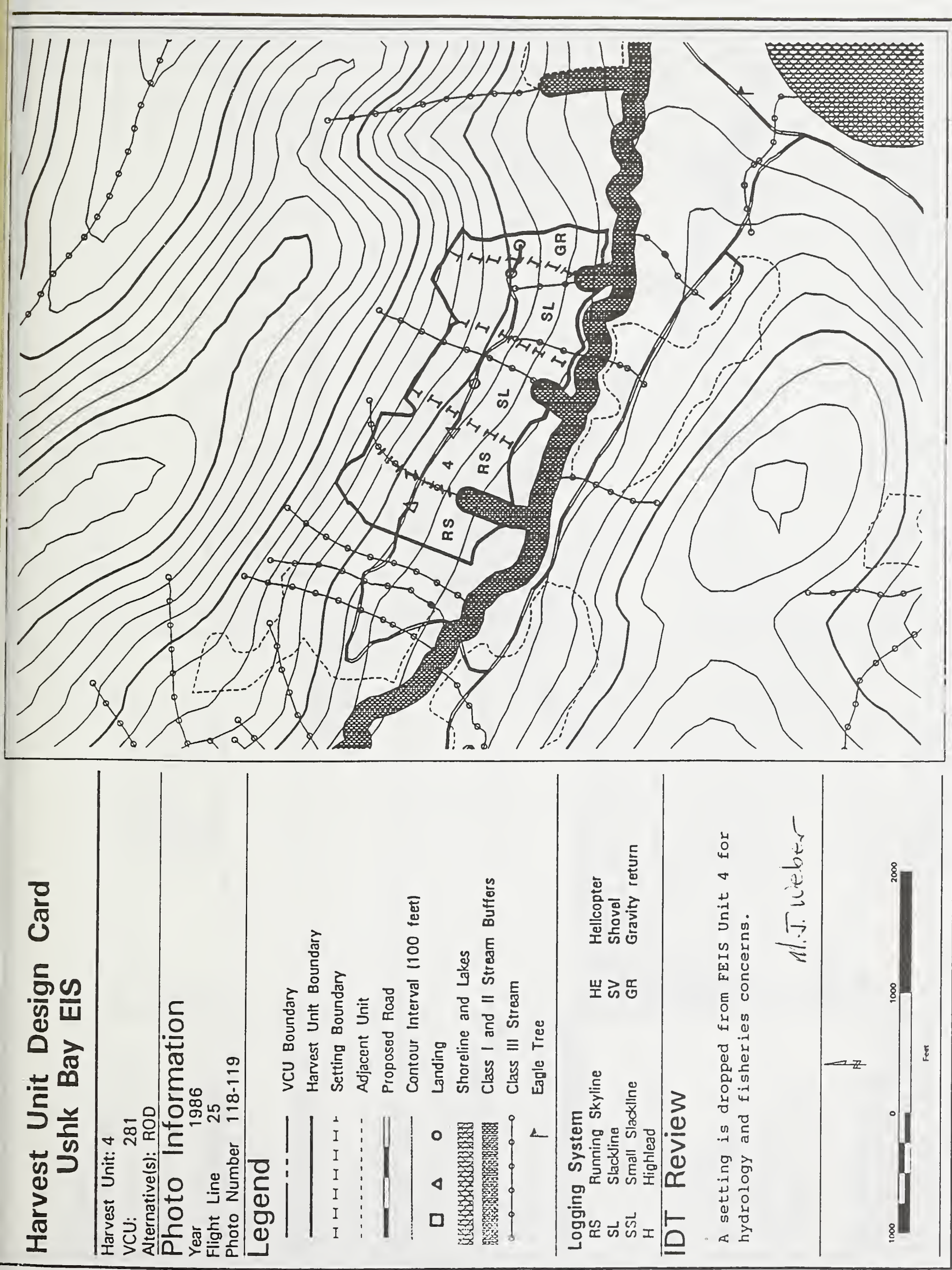




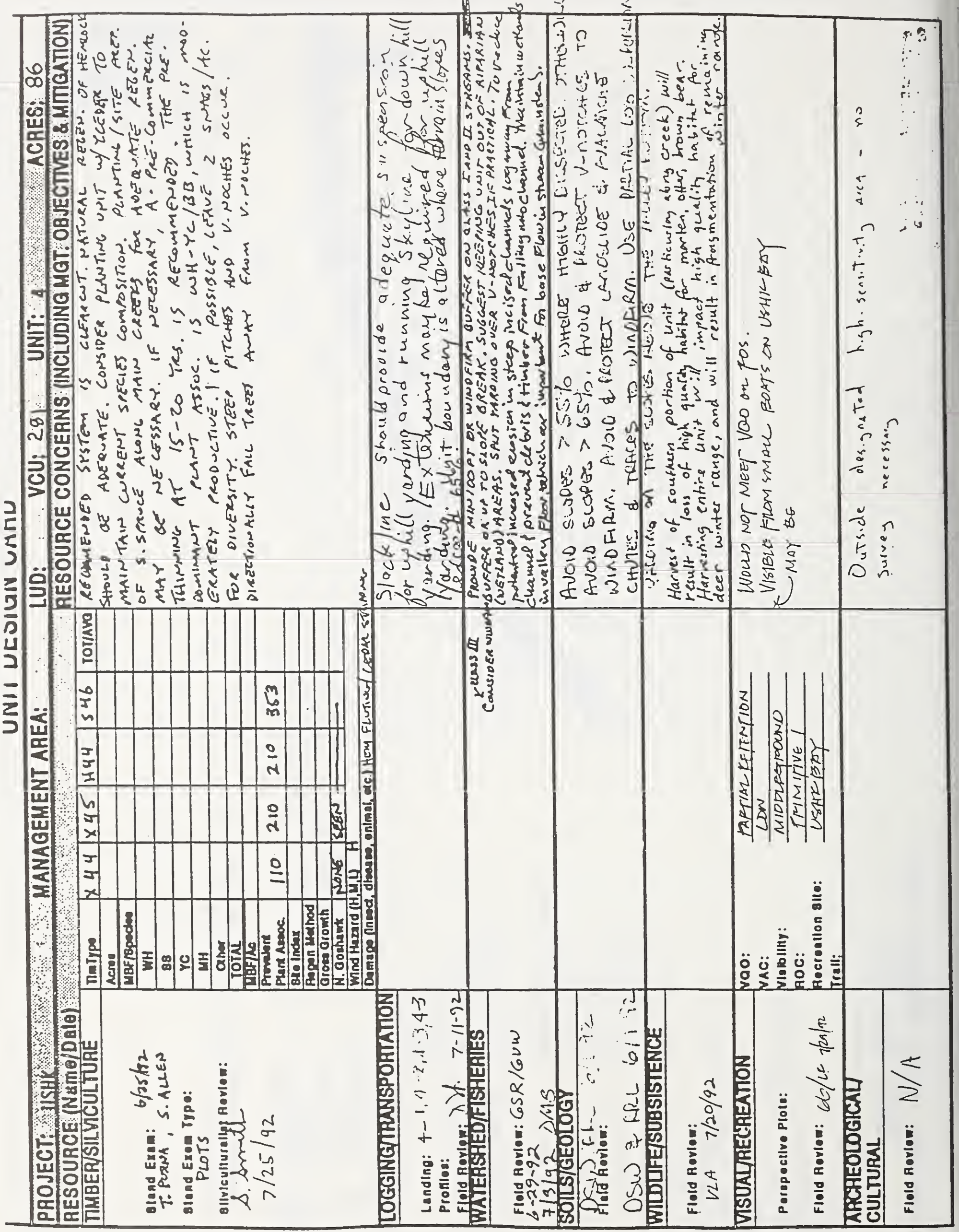




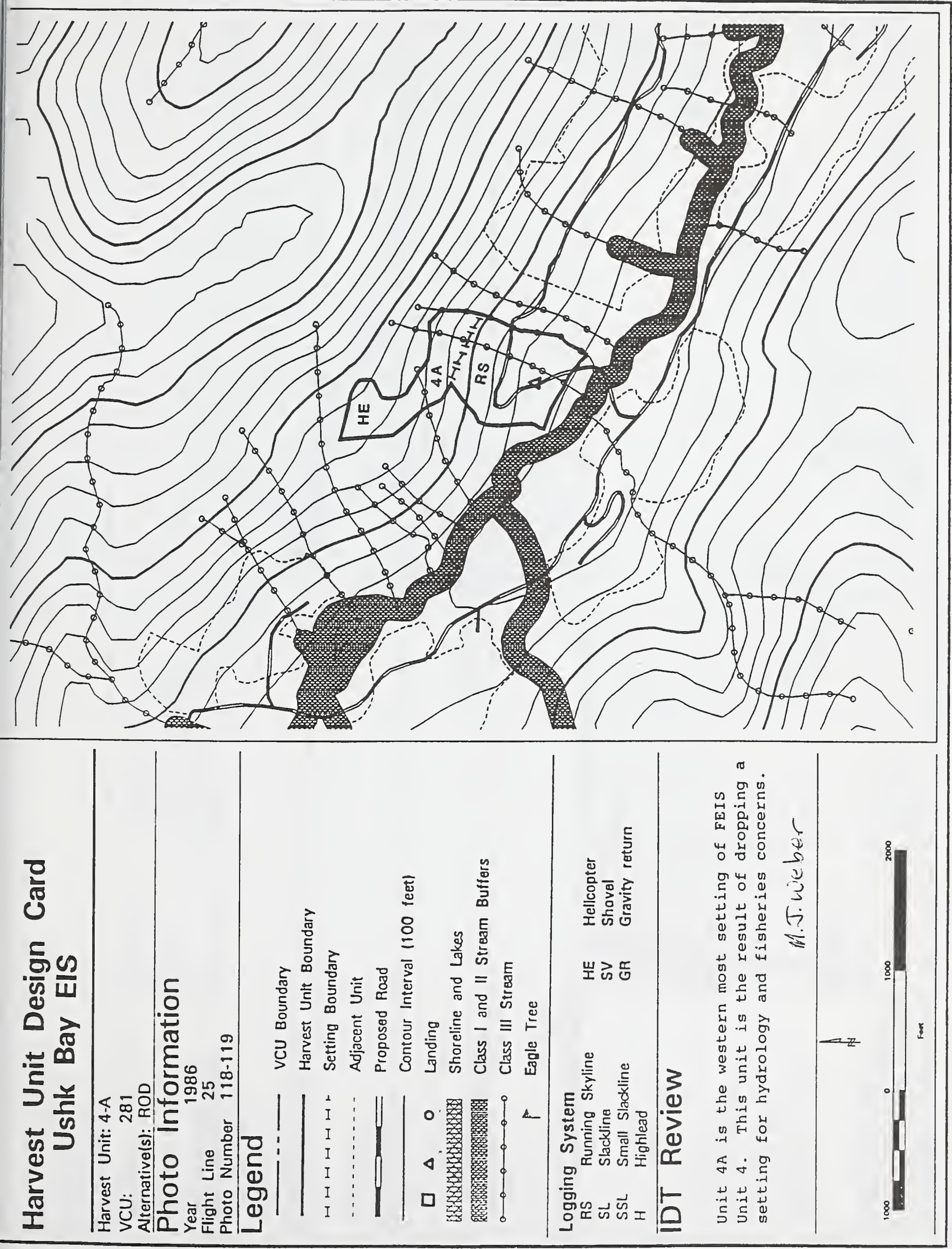


言蒙

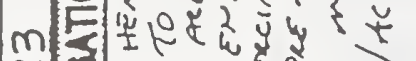

co툴

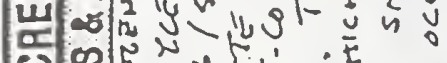

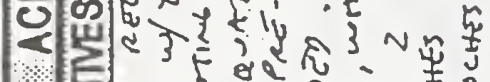

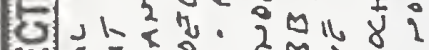

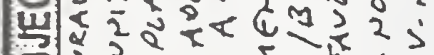

인

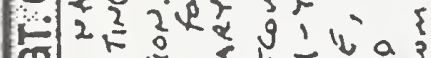

$\checkmark$ 울

मे 3 उ

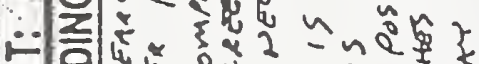

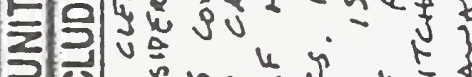

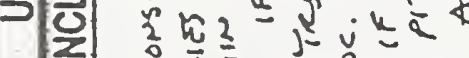

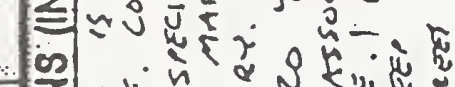

की

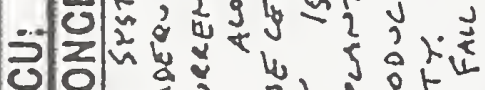

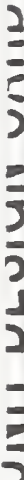

$>0 a^{2} 3 y^{2} t^{2} \frac{2}{2}$

च س

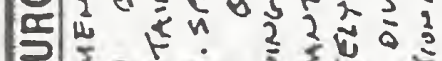

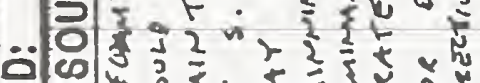

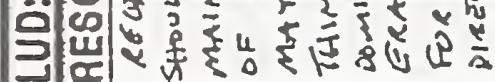

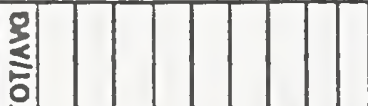

.

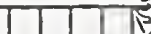

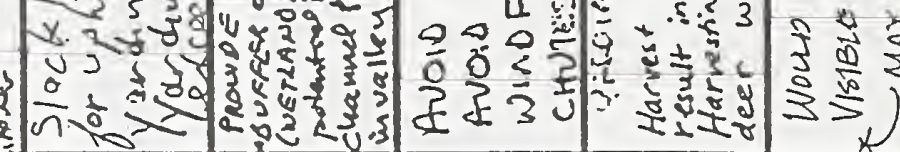

2)

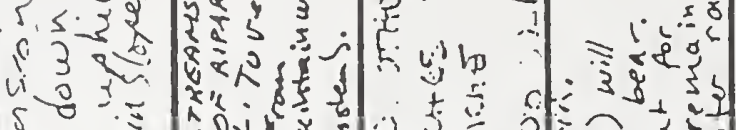

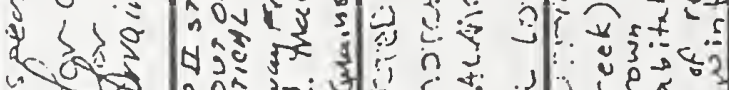
a.

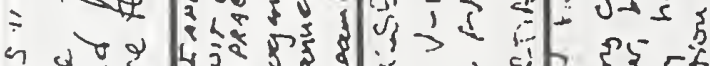

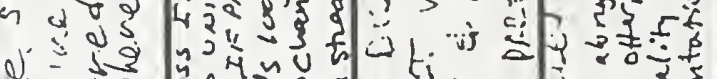

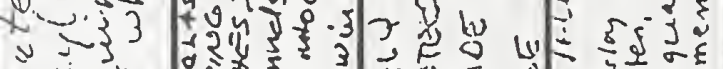
उ- $x$ a 3 in

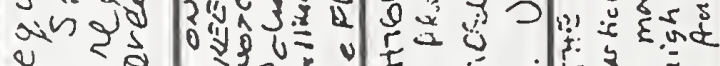

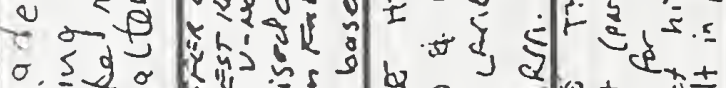
$0.5 \sqrt{2} \sigma x^{2}$

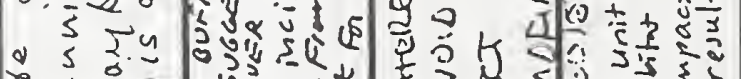
- $\begin{aligned} & 0 \\ & 0\end{aligned}$

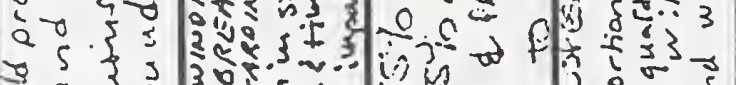

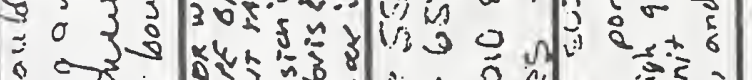

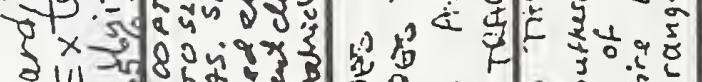

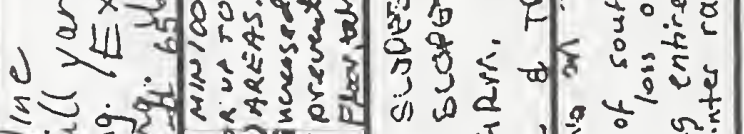
峁
N/C :

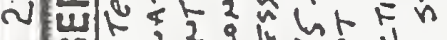

药

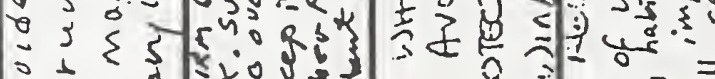
$3 . .50$. $x$ - 53 s

年 10

lo

$x$

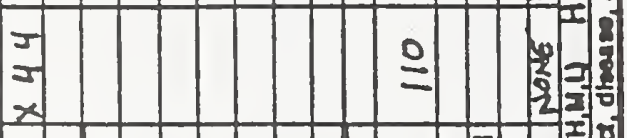

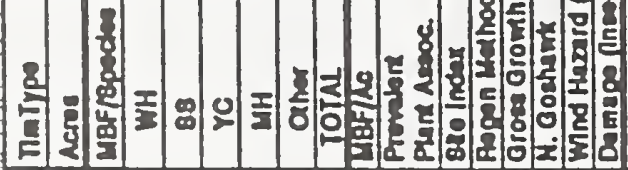

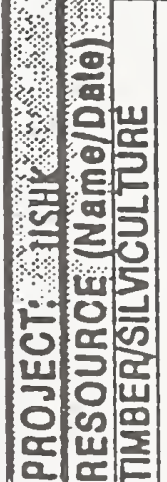

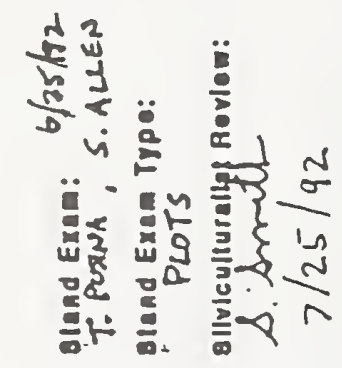

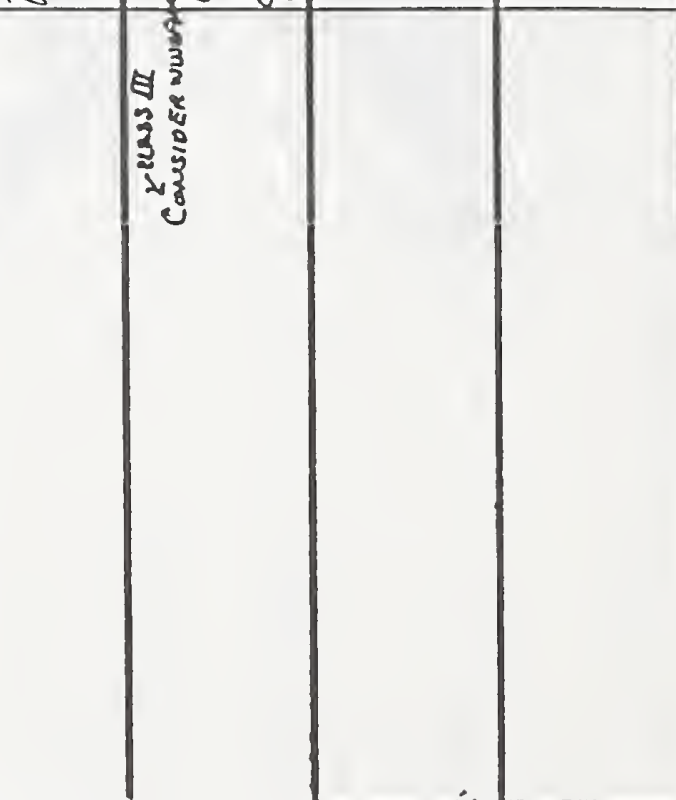

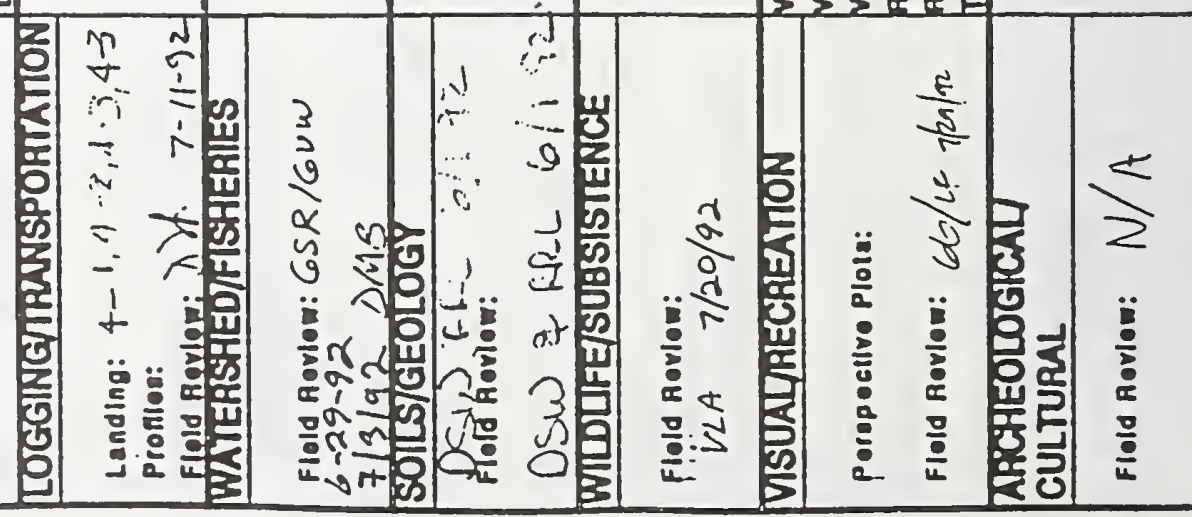




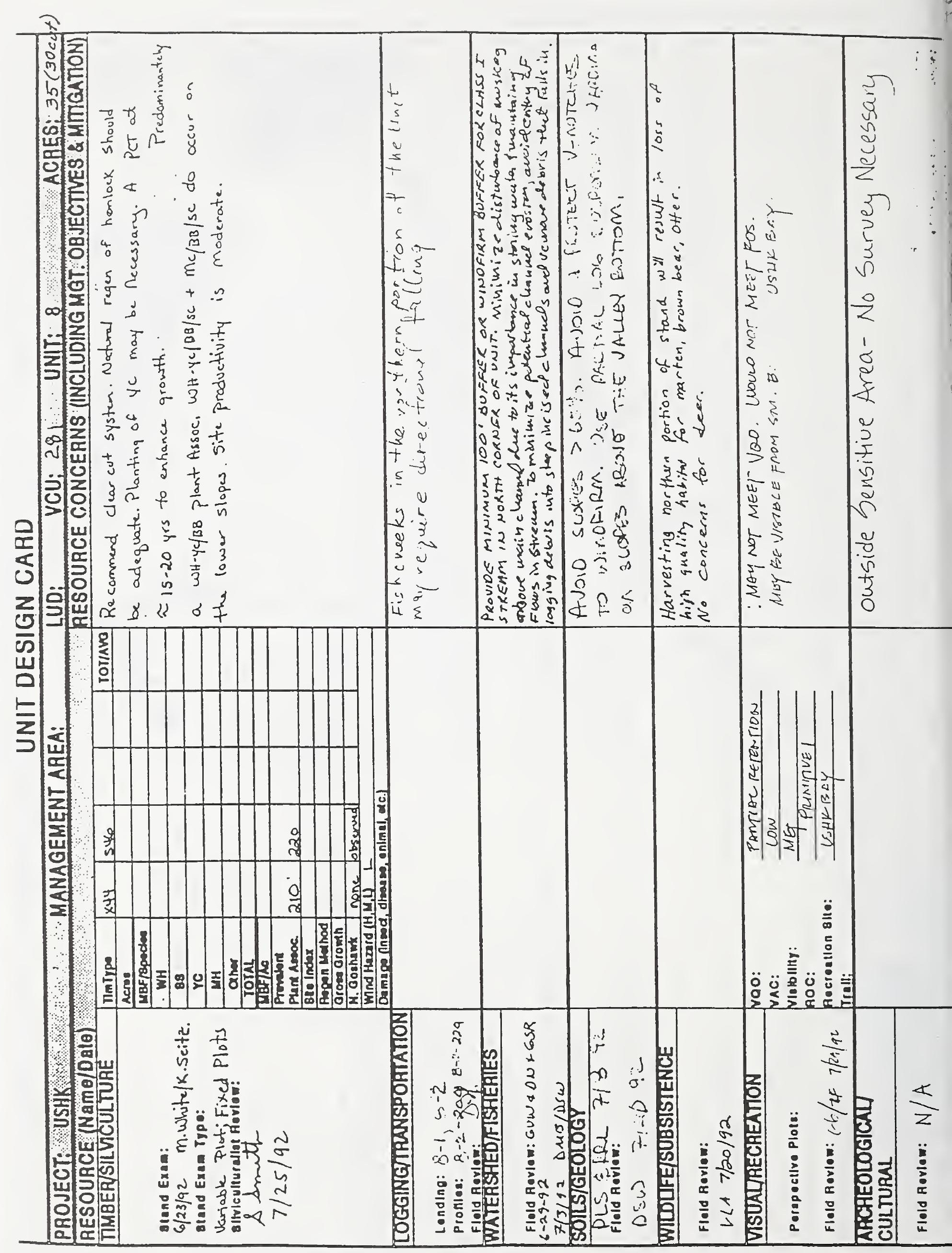




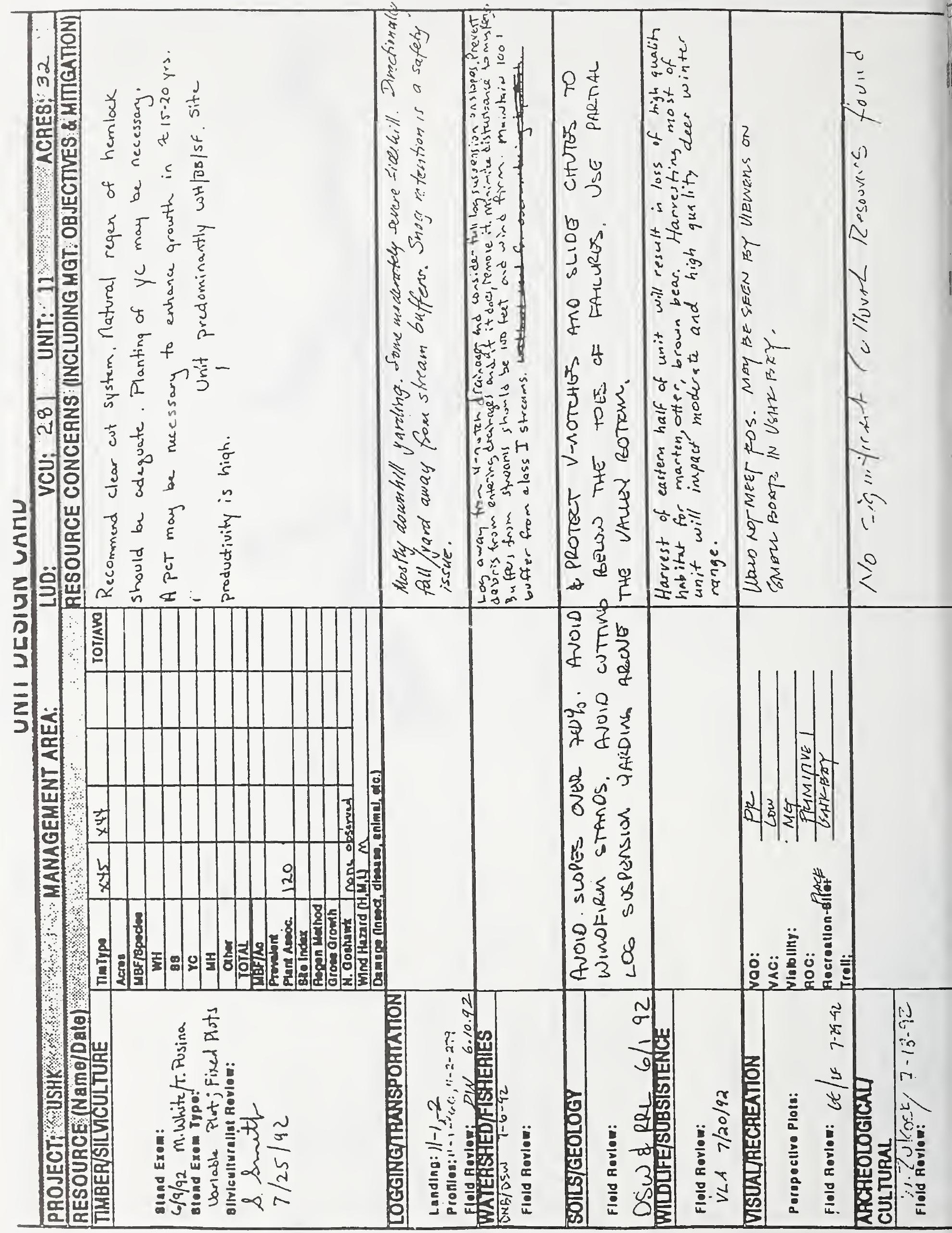




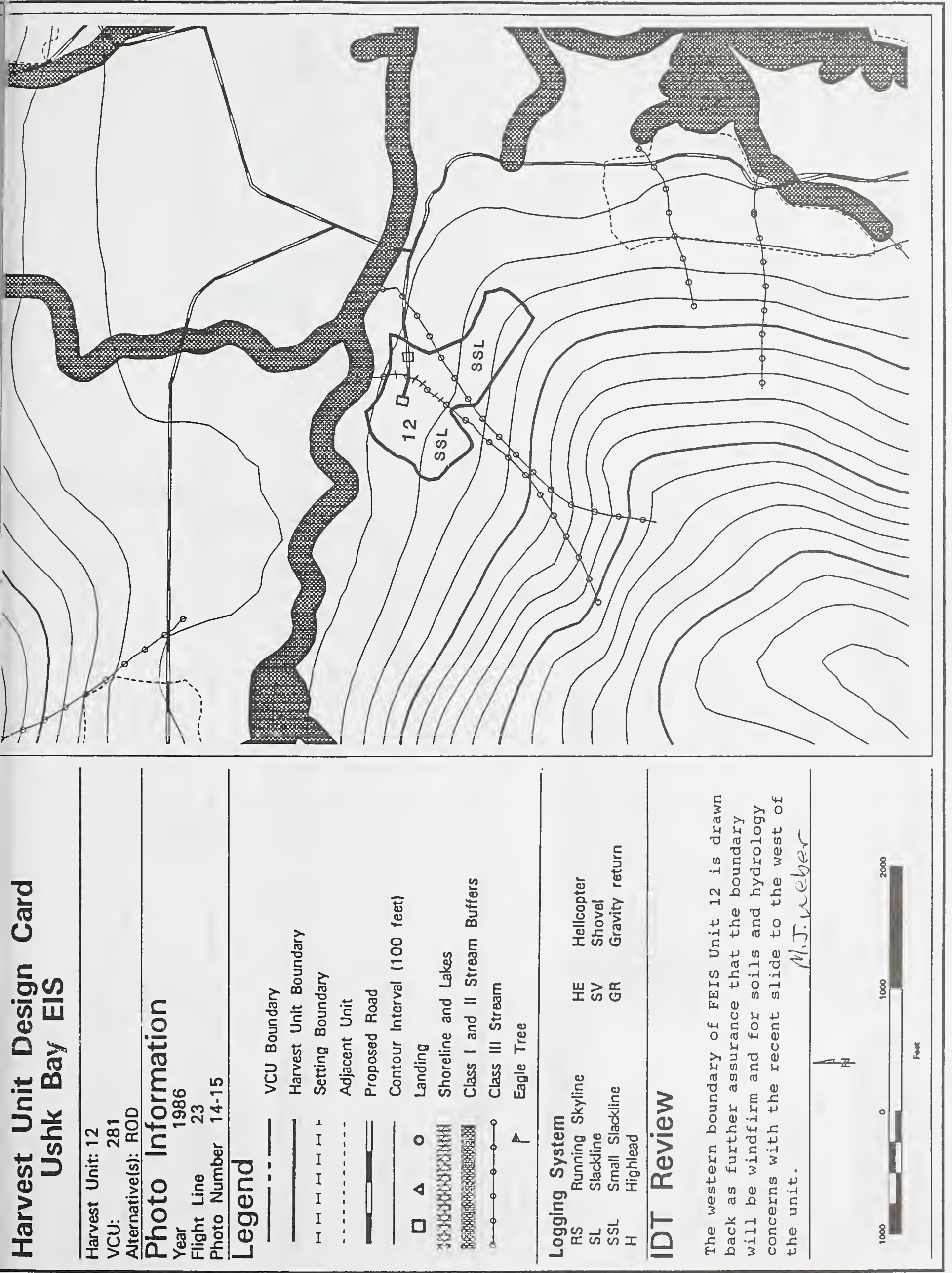




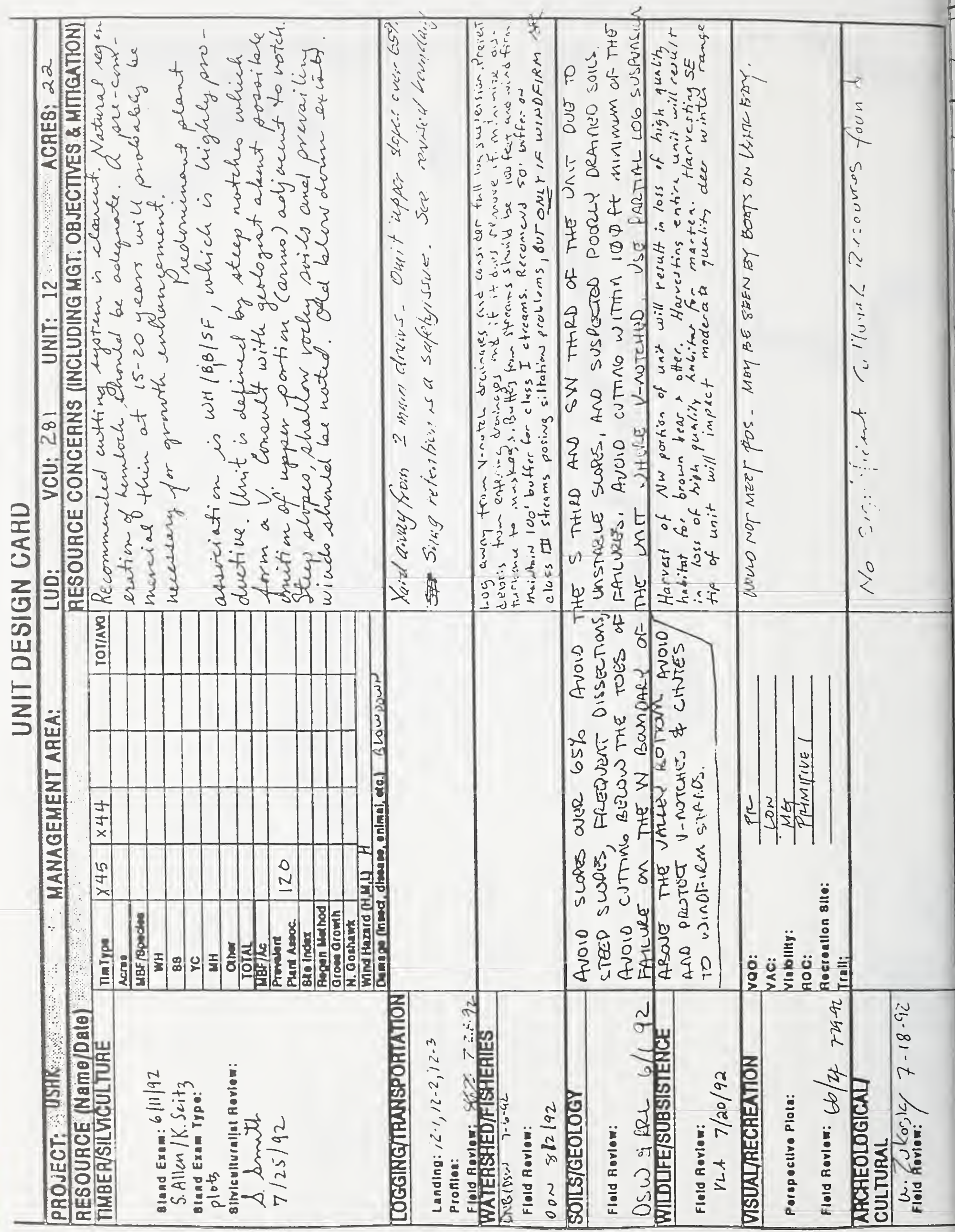




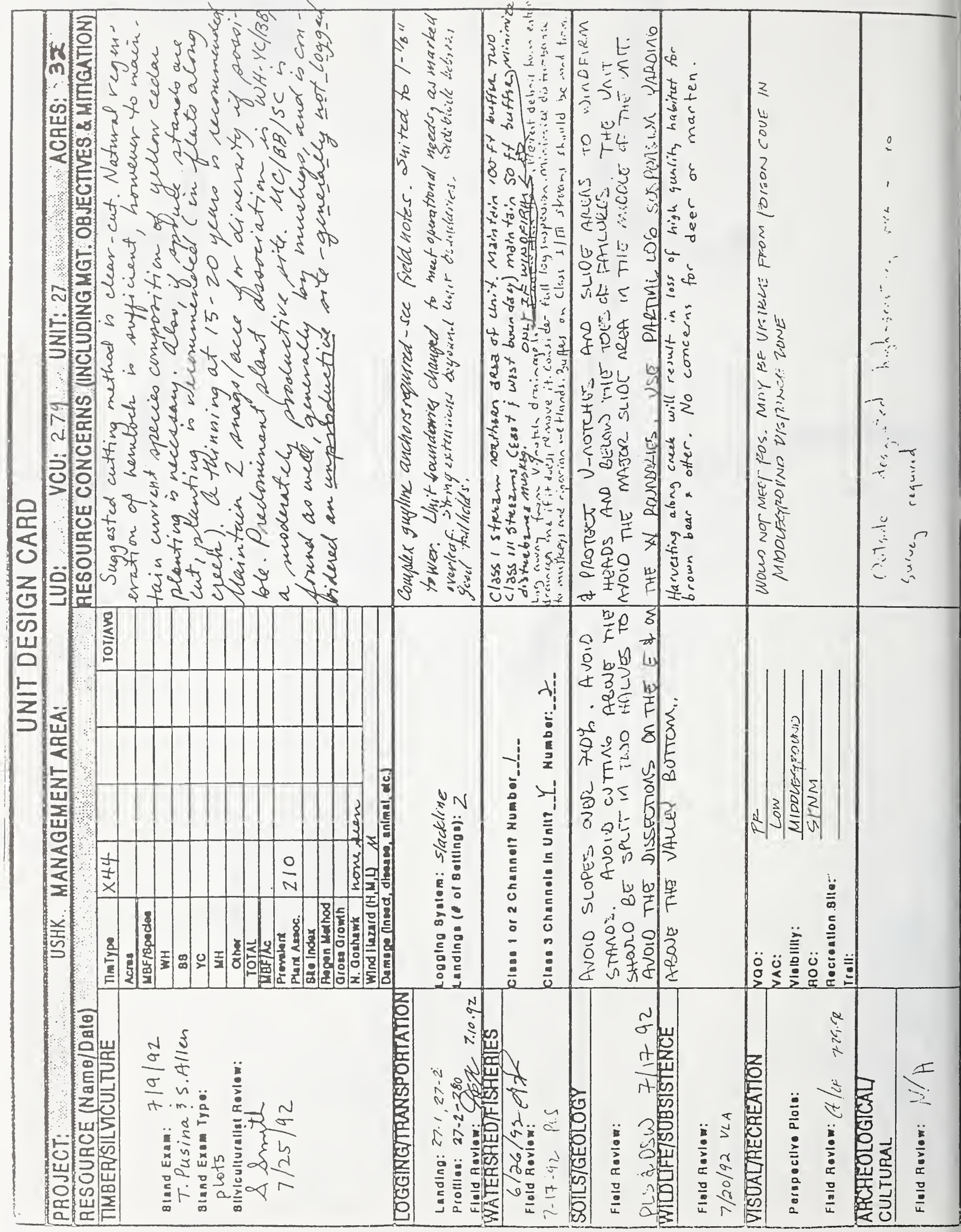




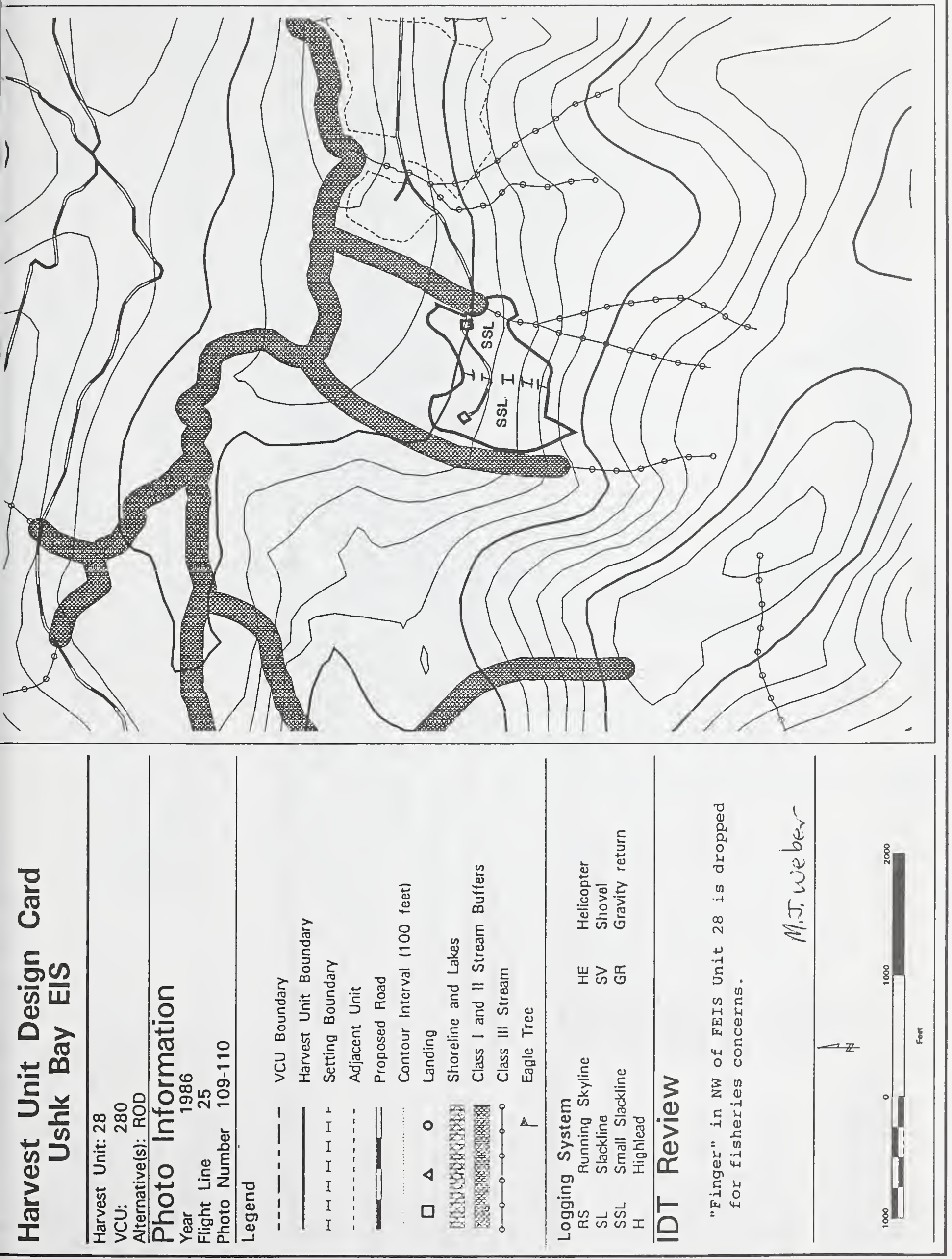




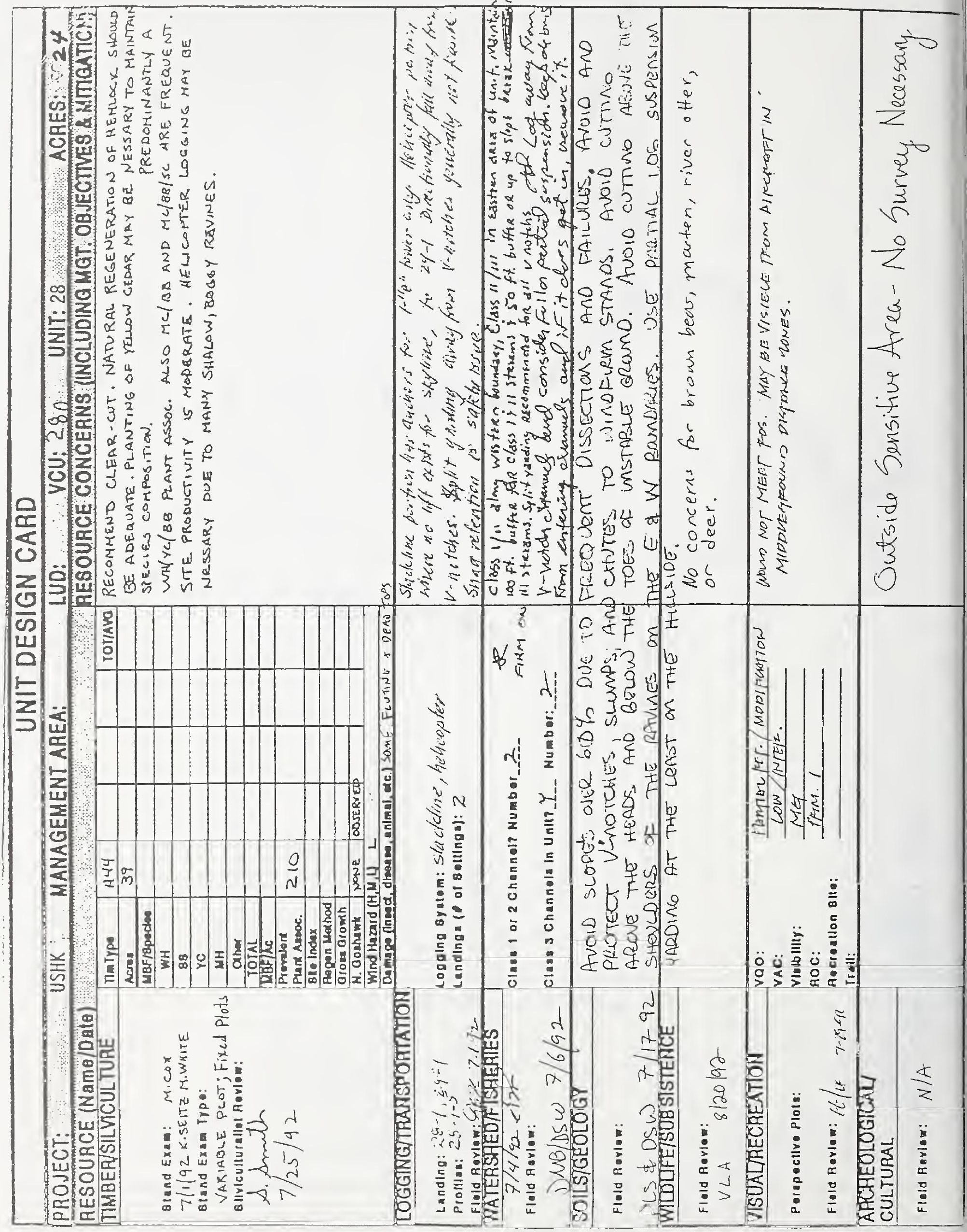




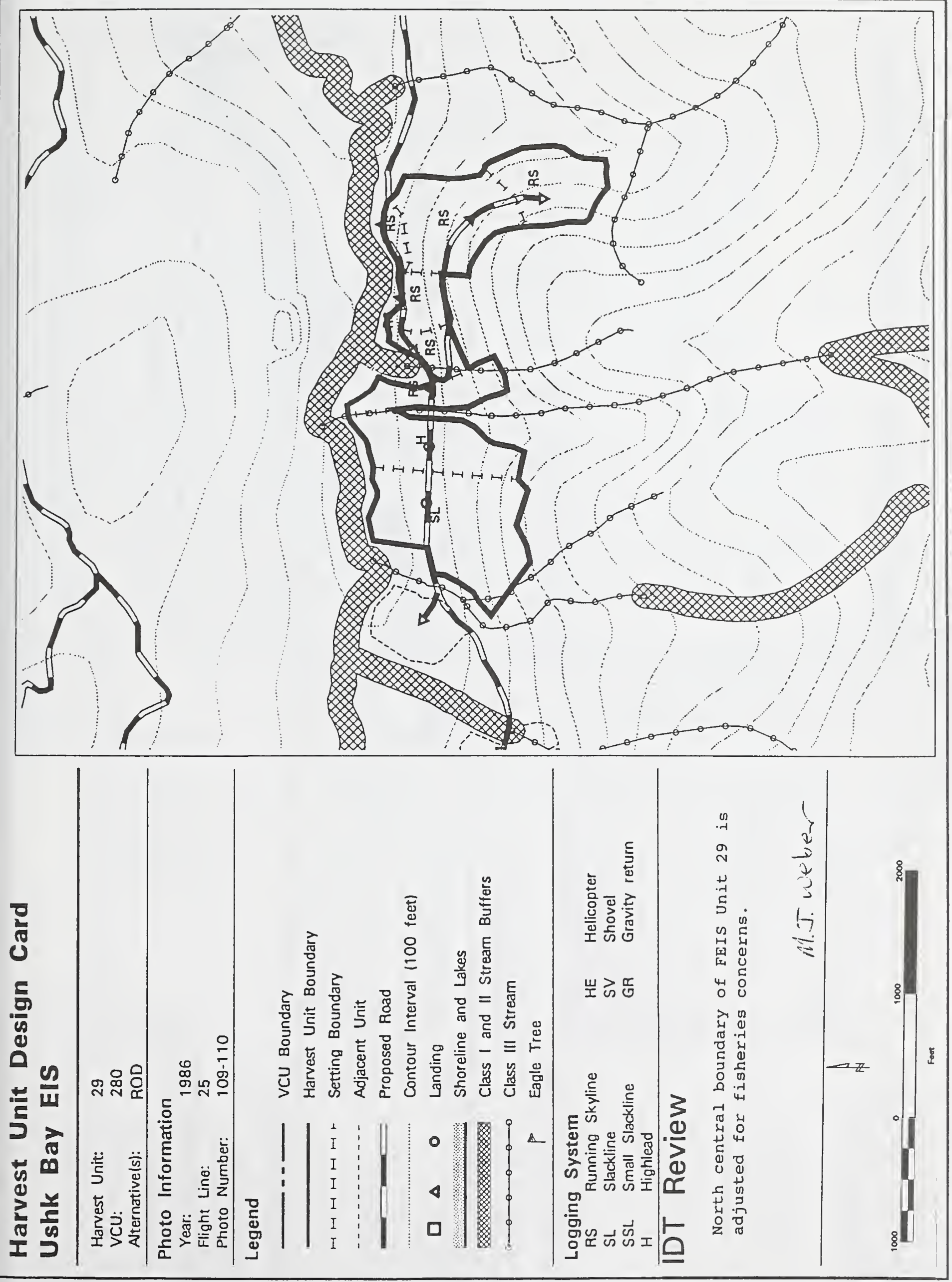




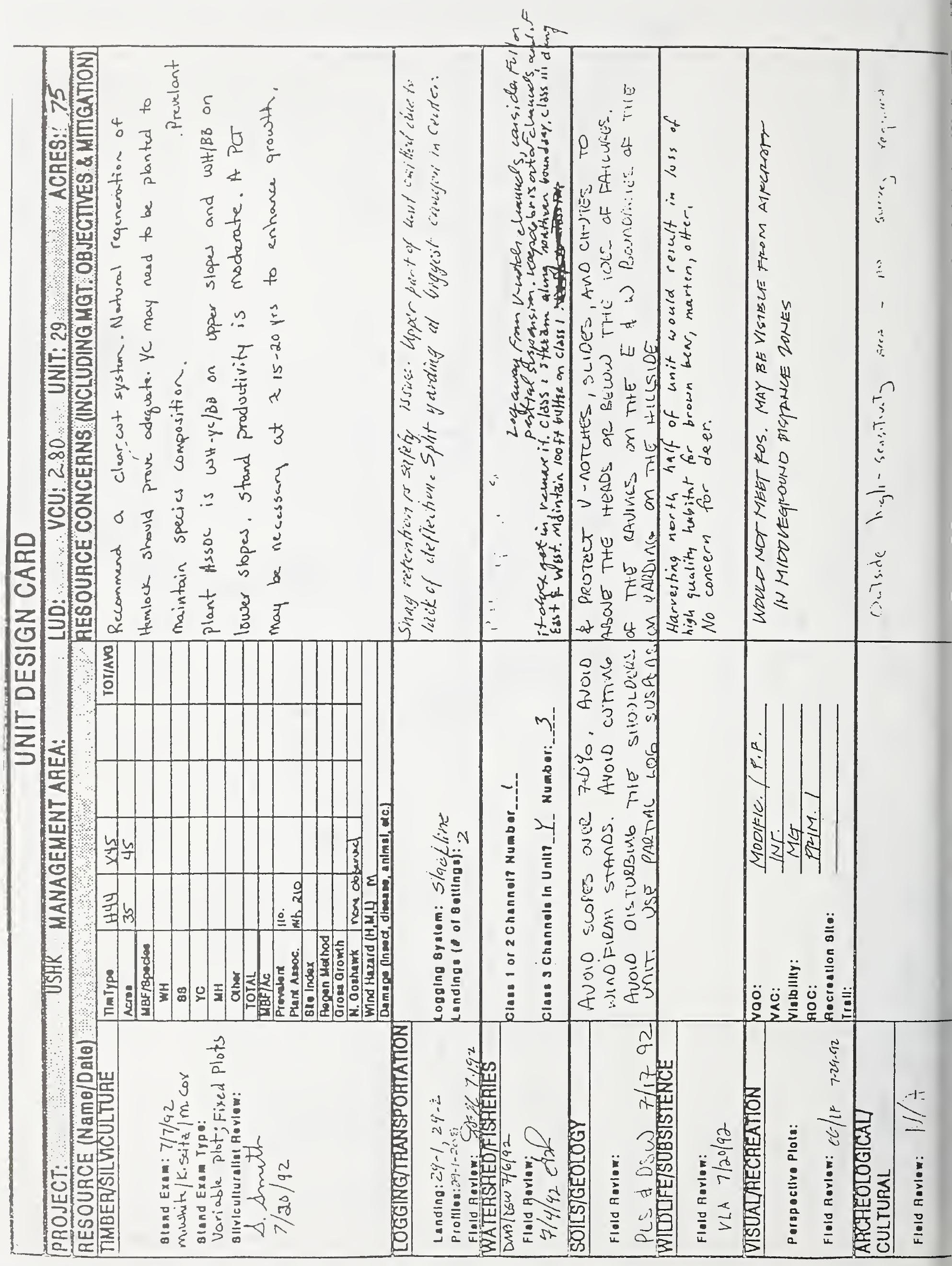




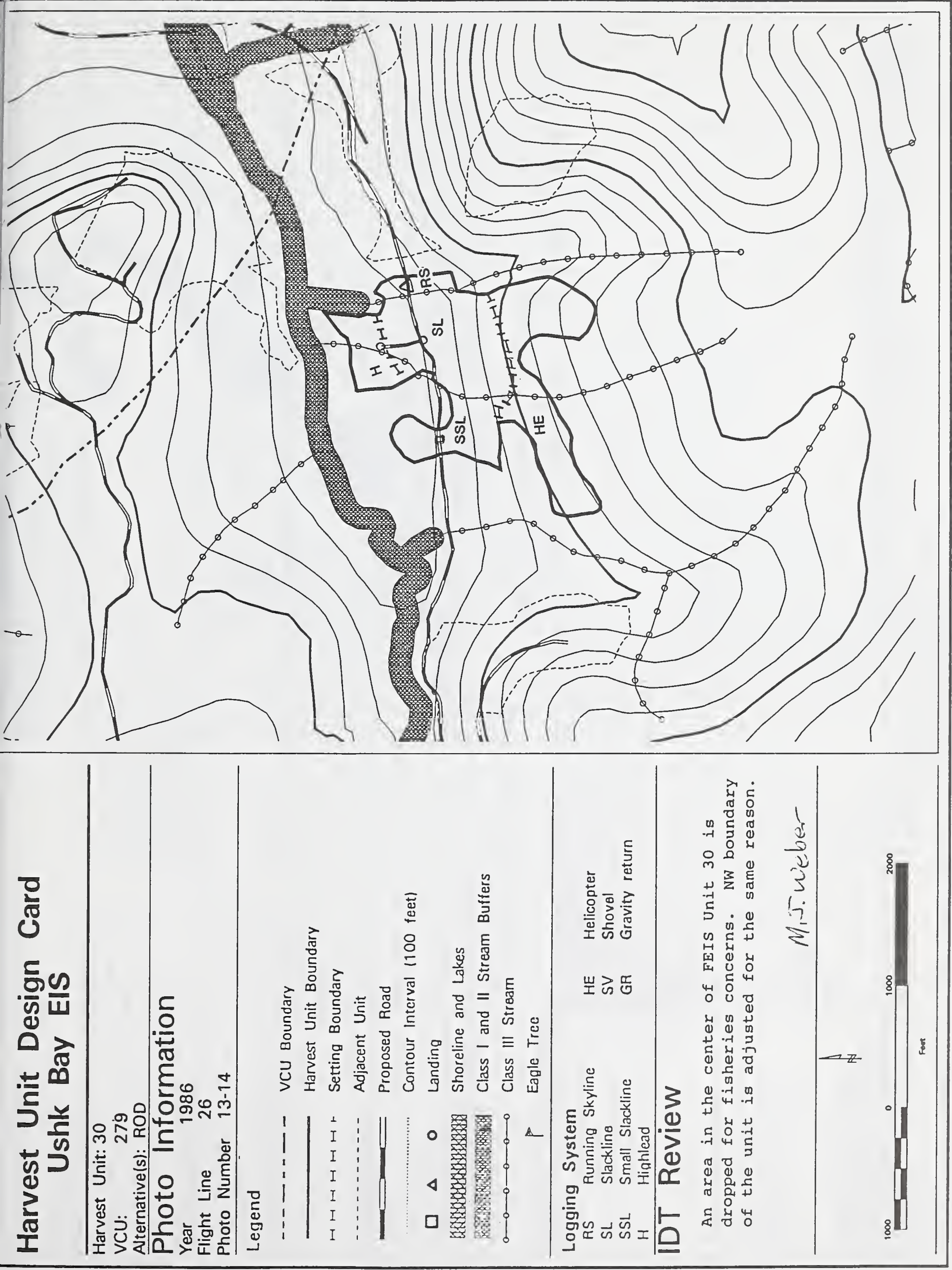




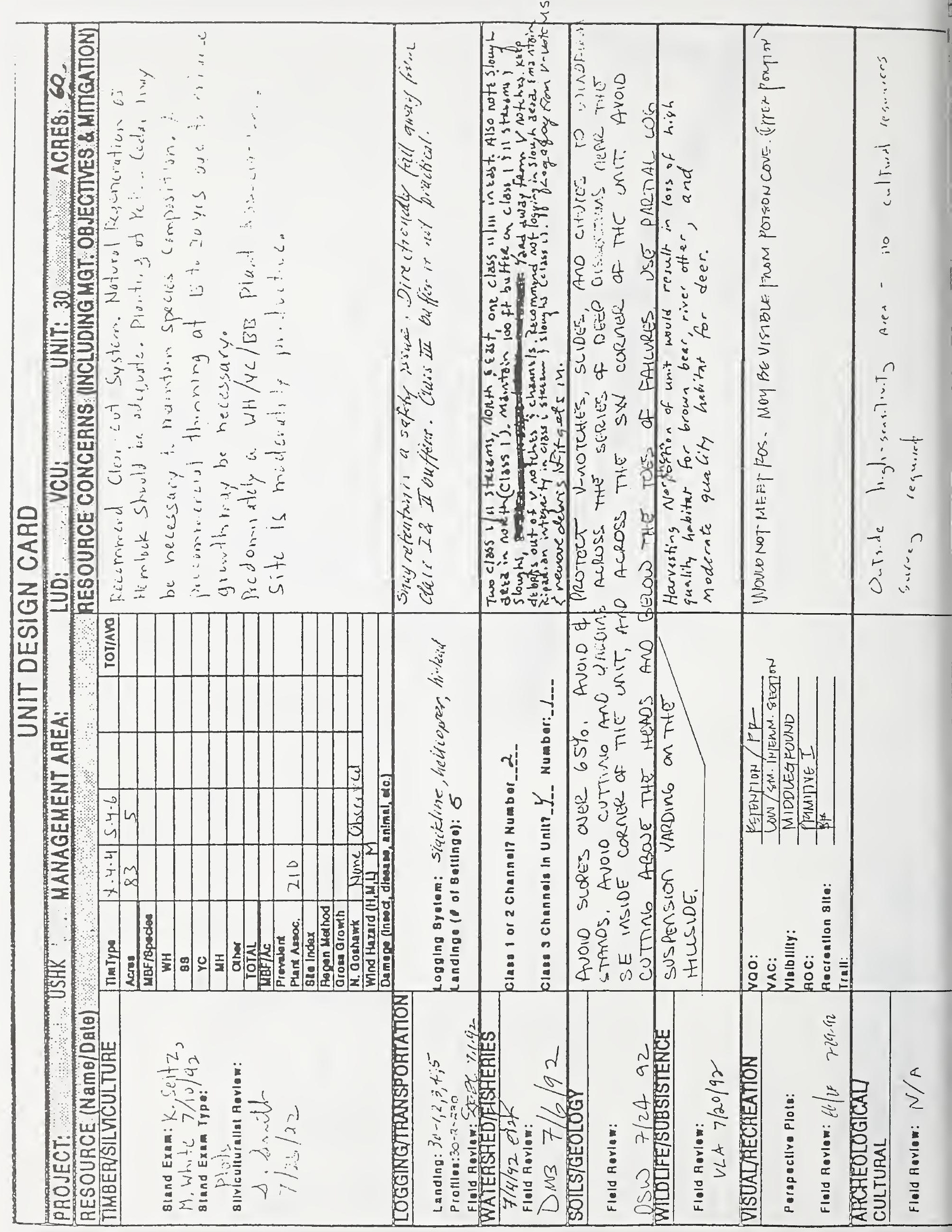




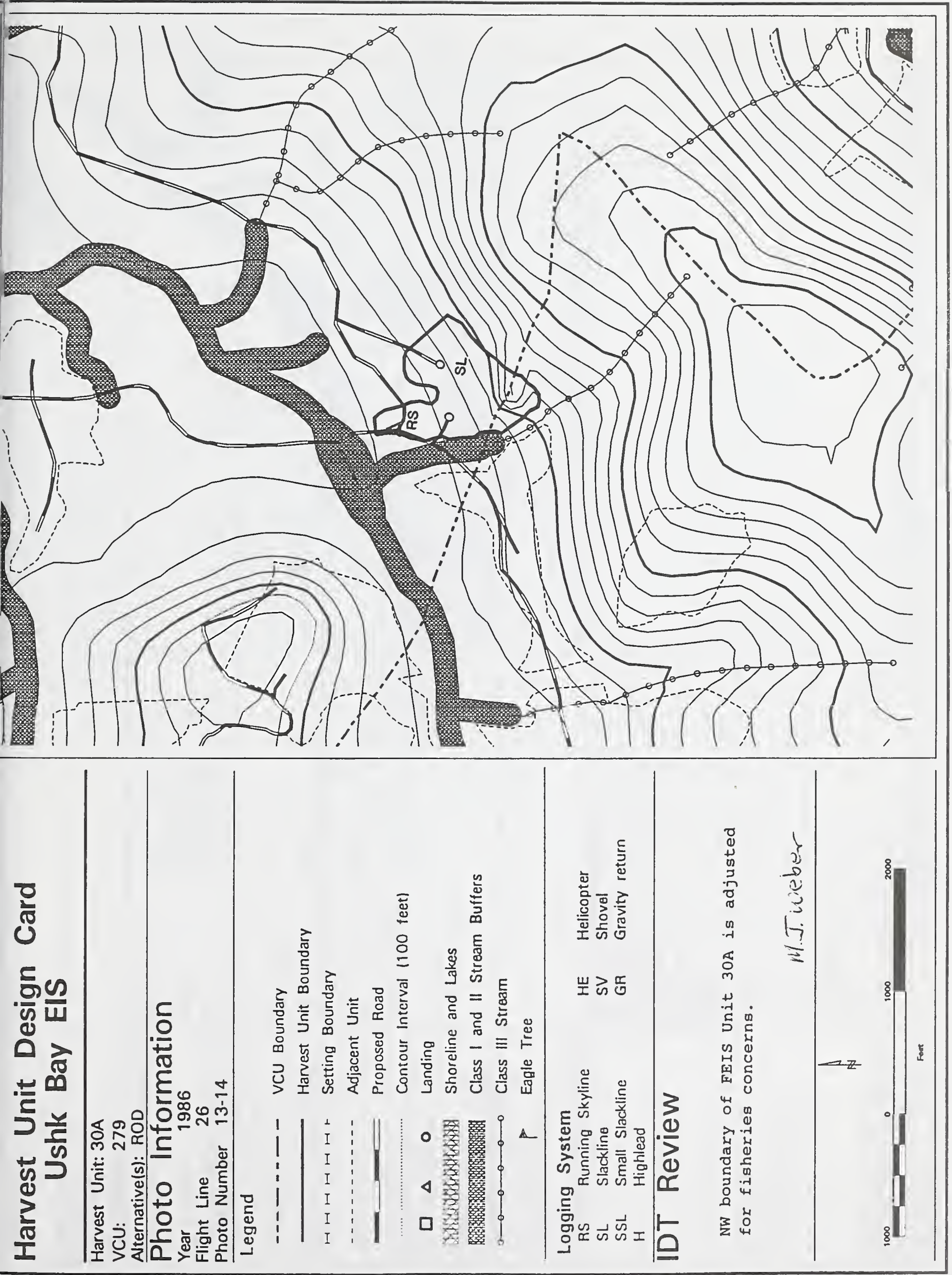




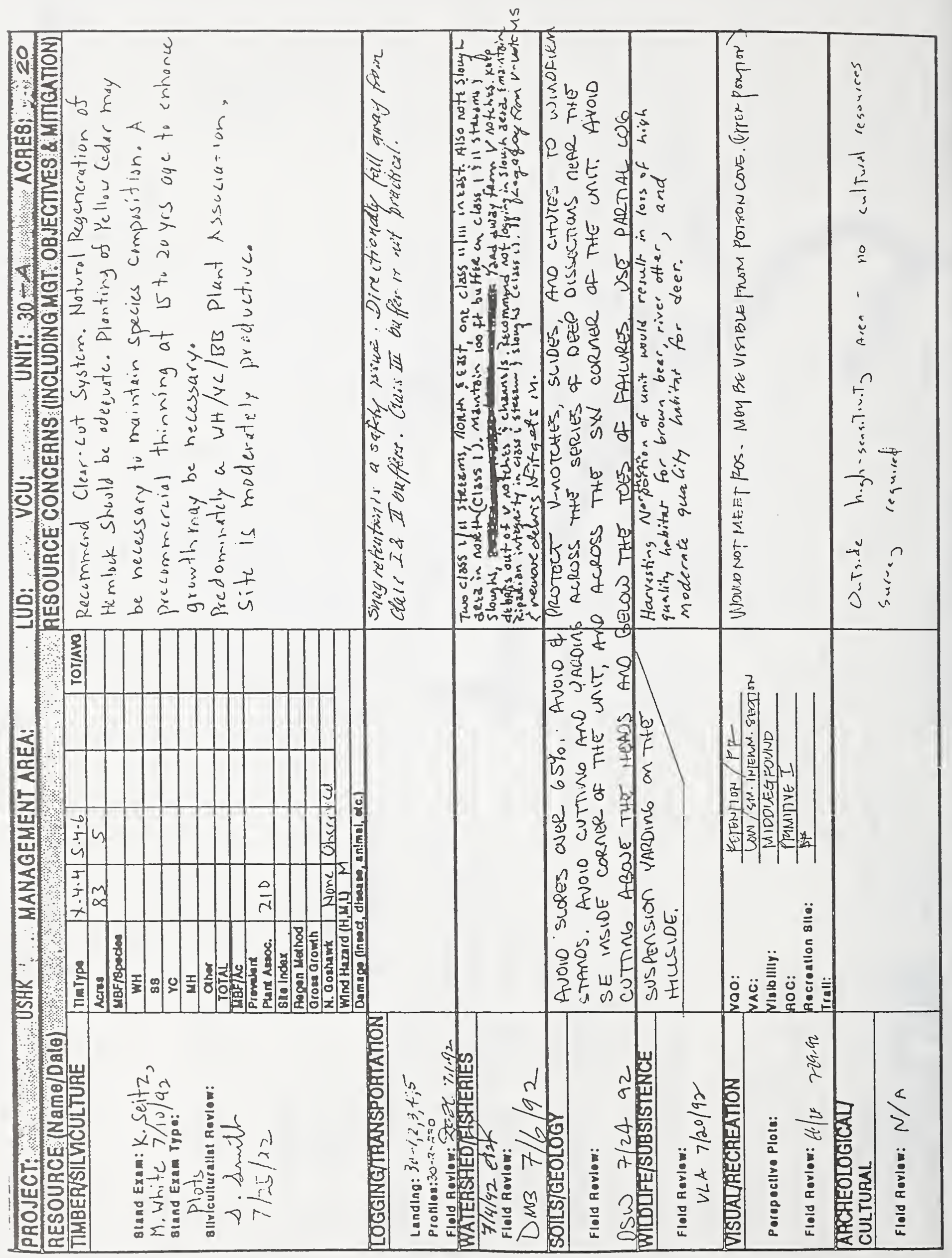




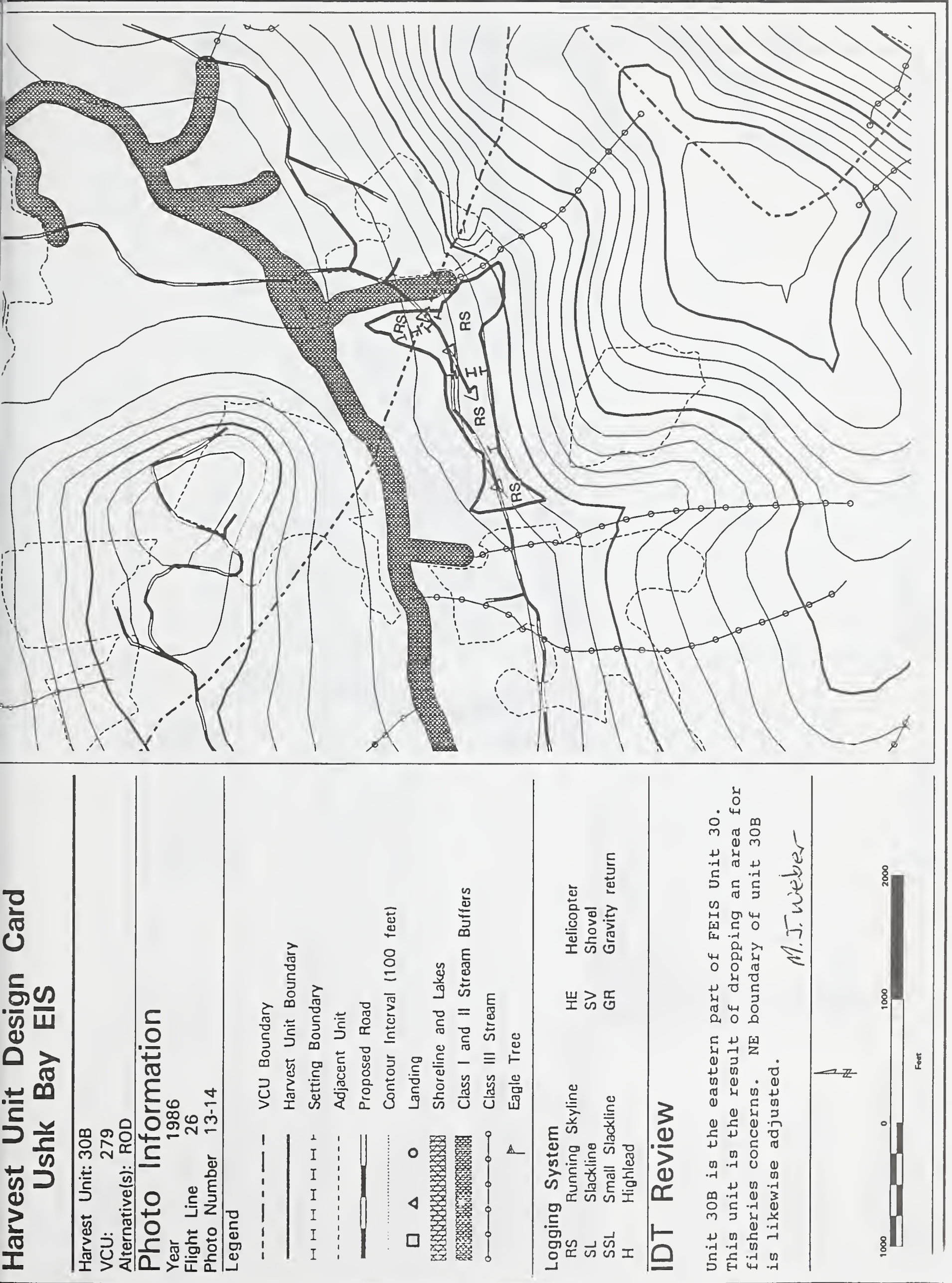




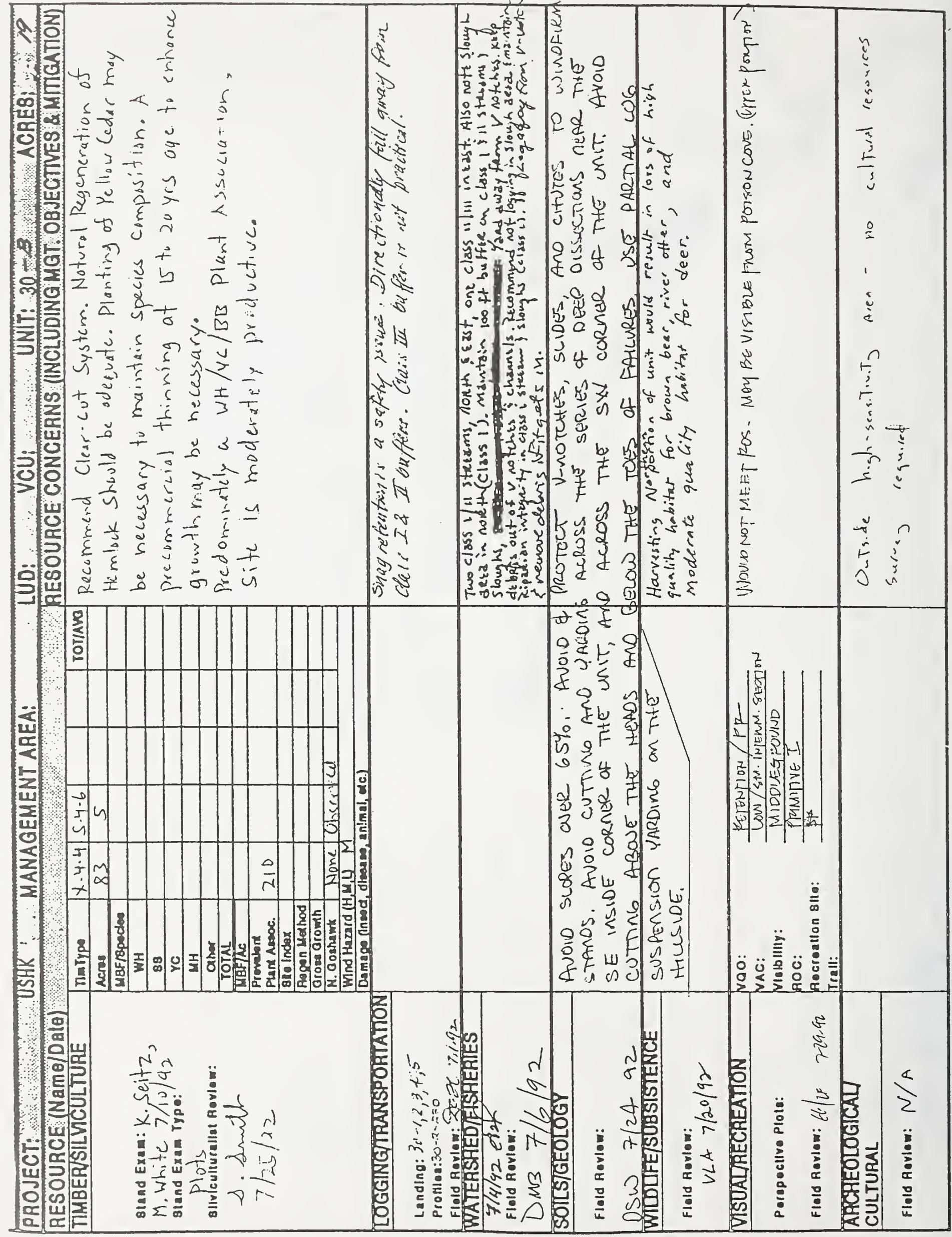




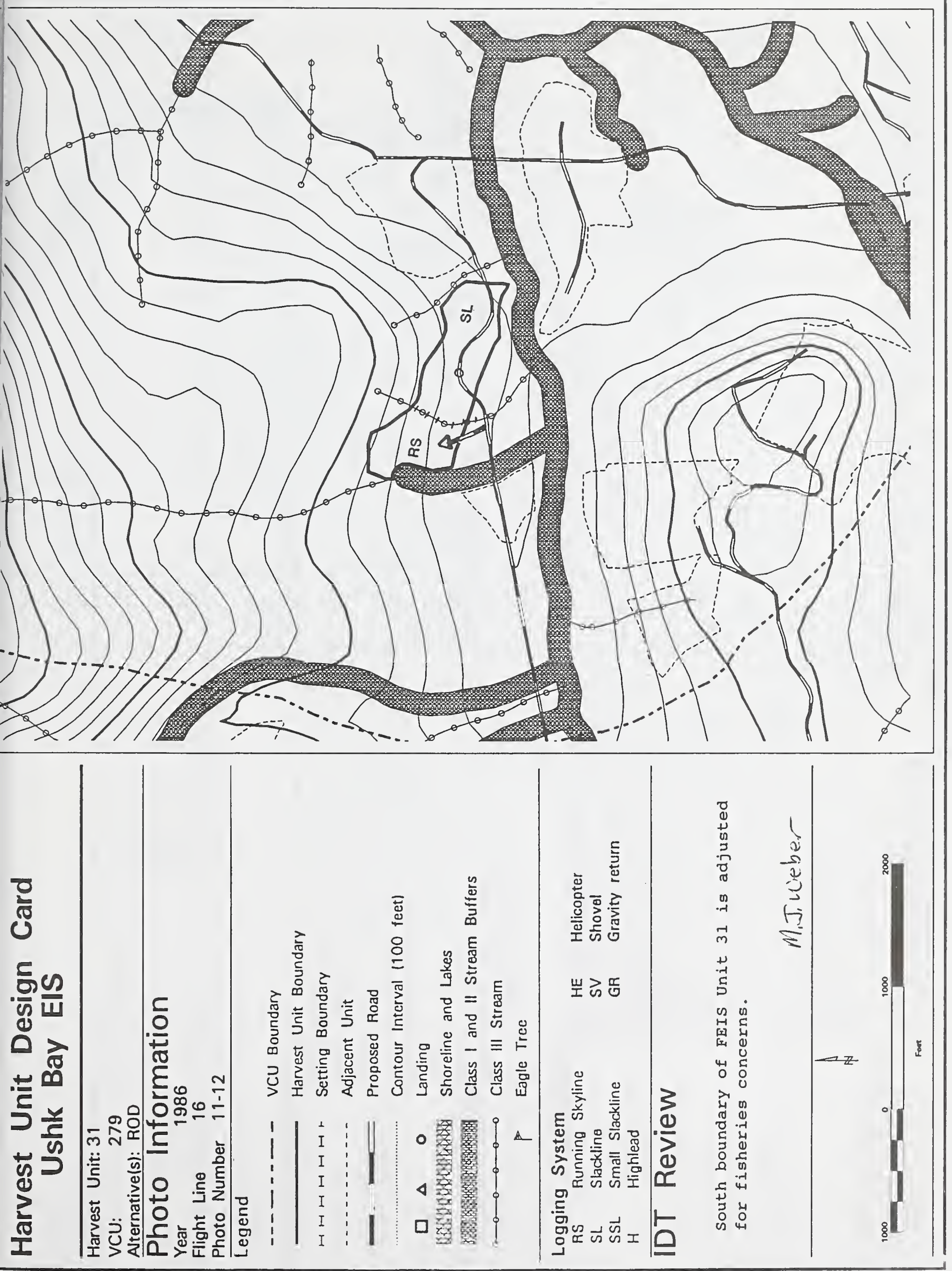




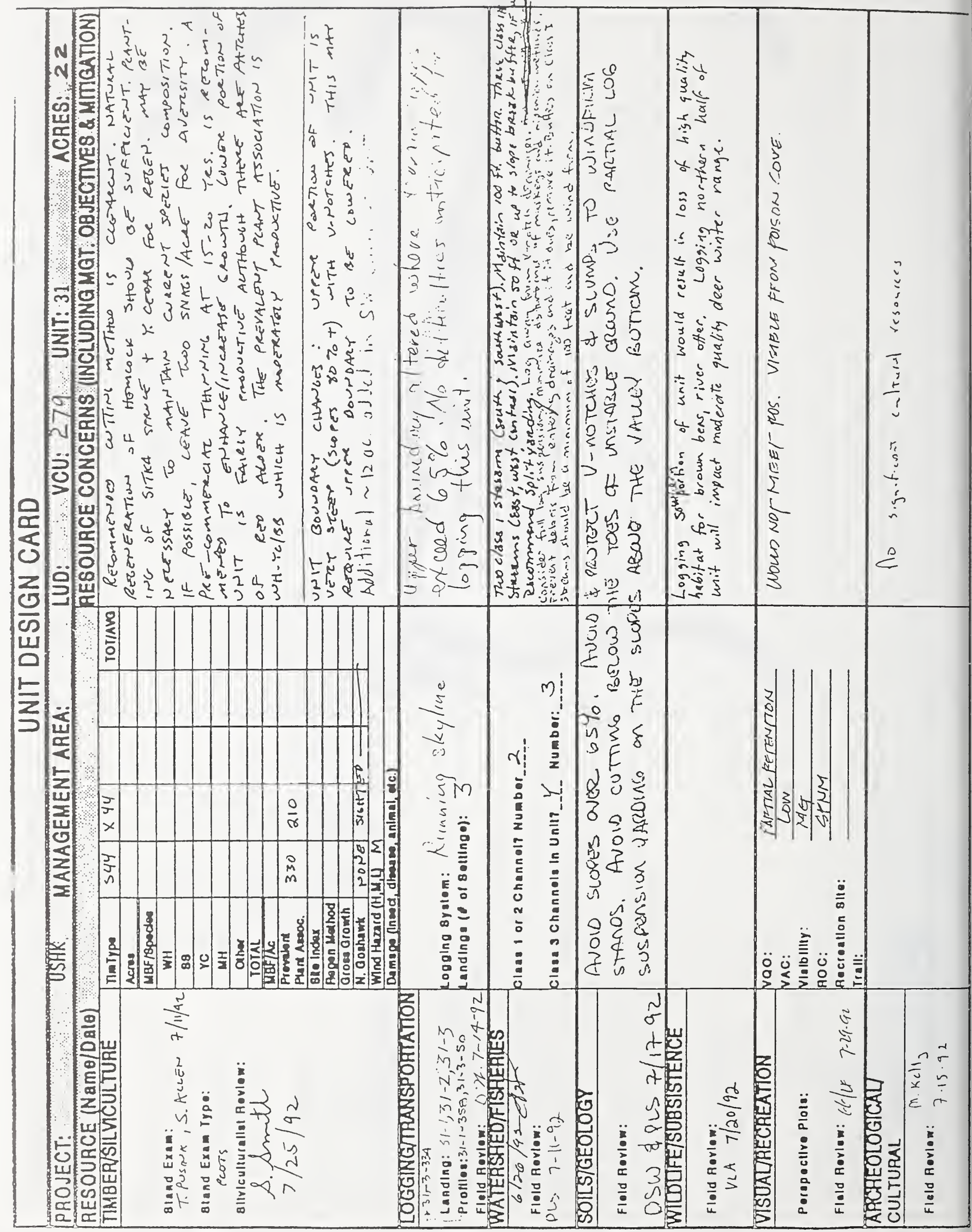




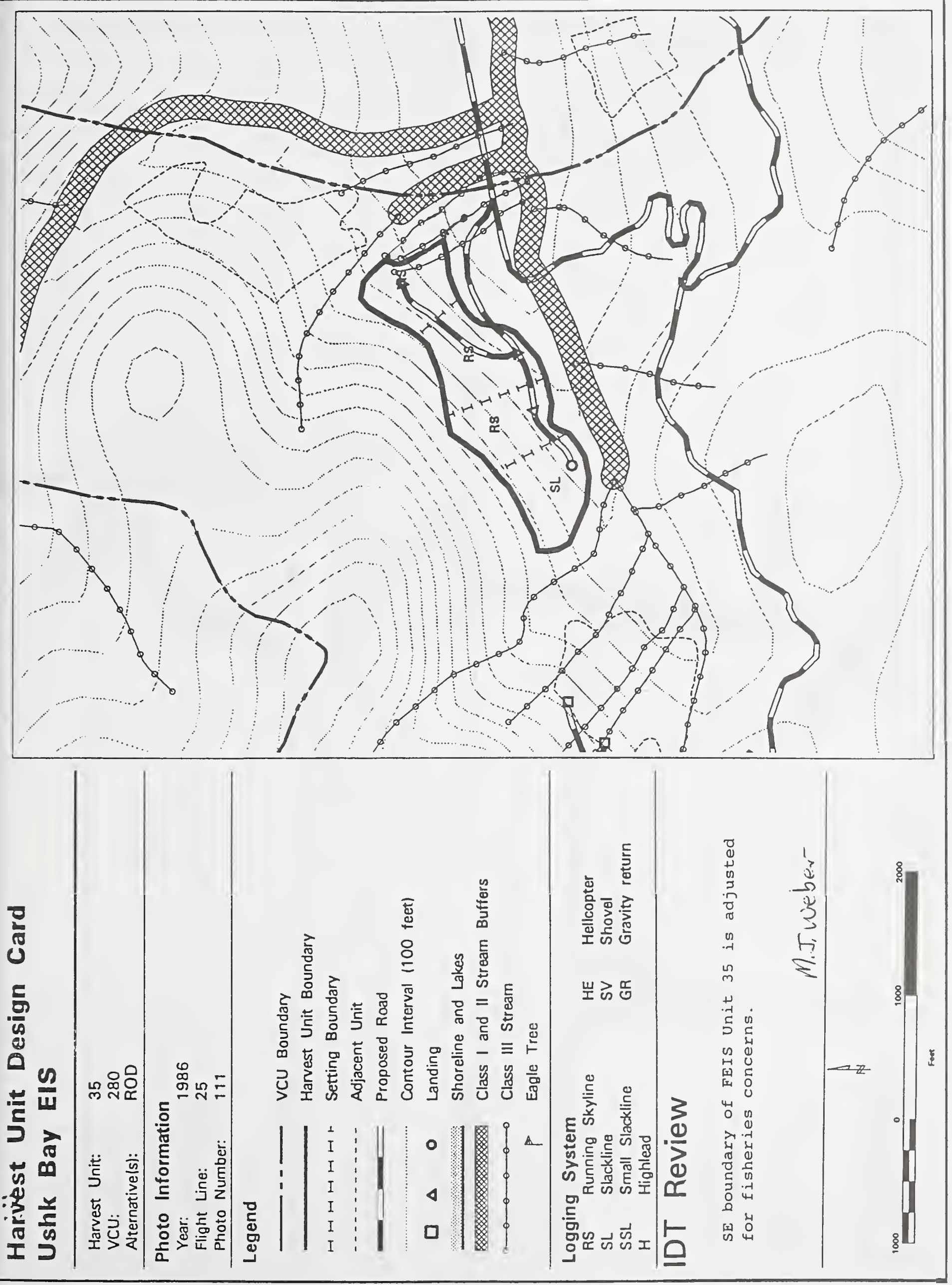




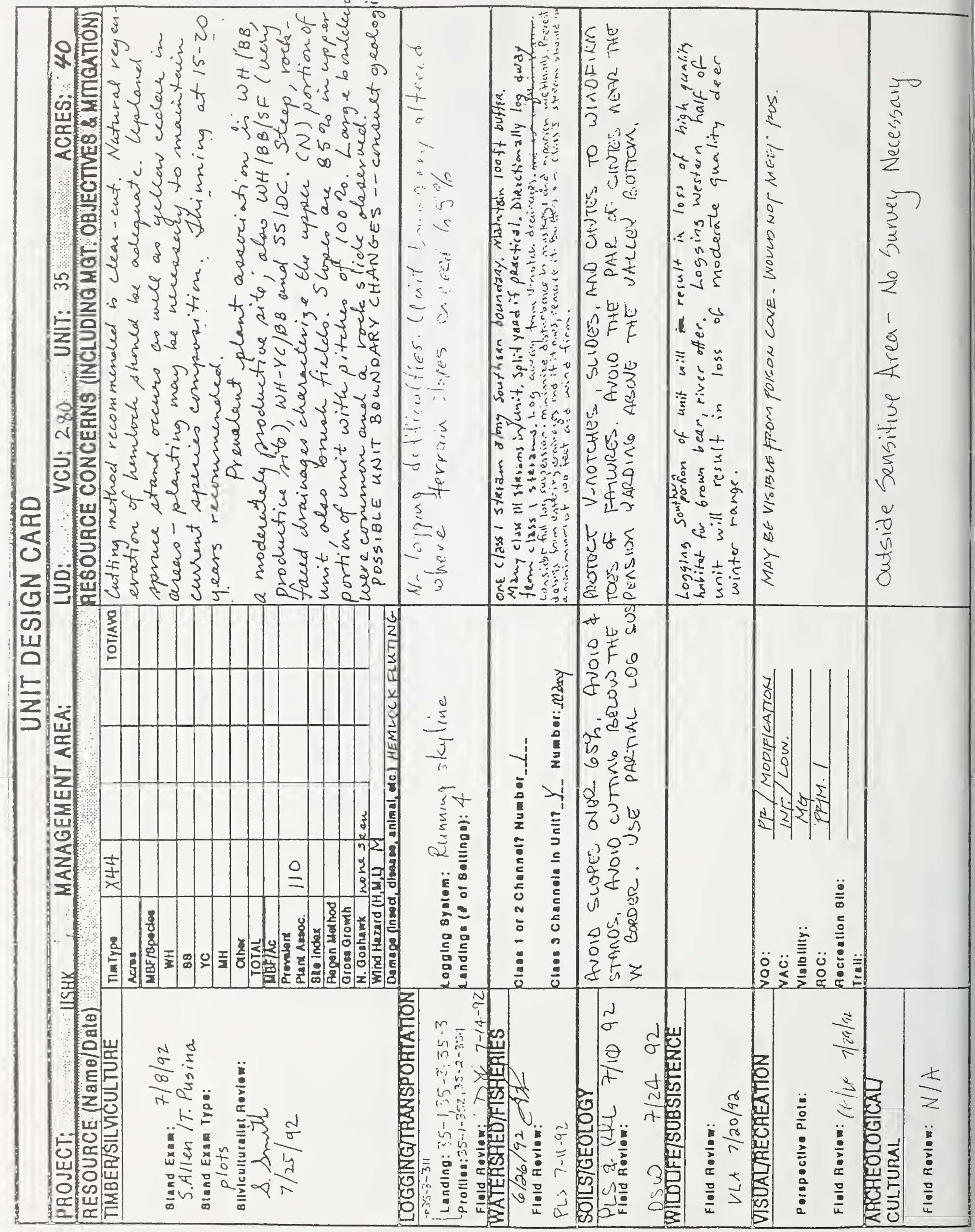




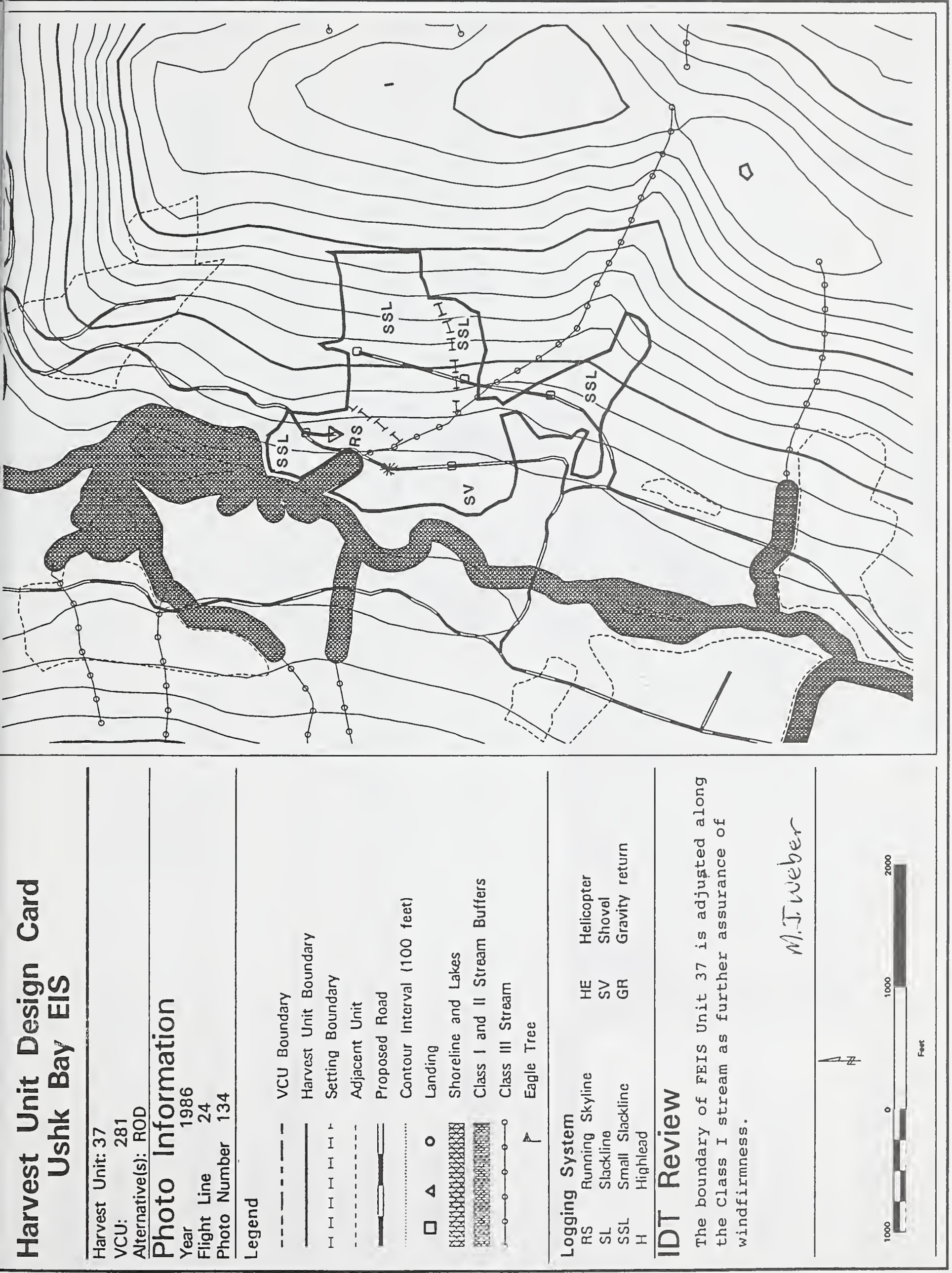




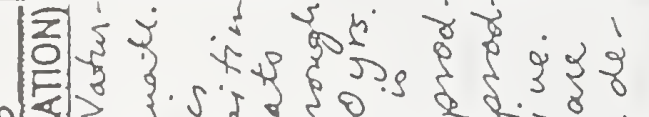

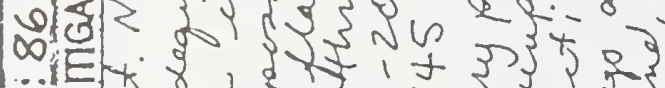

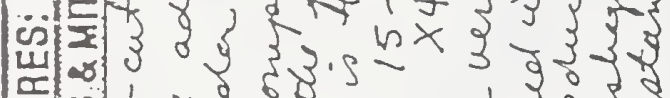

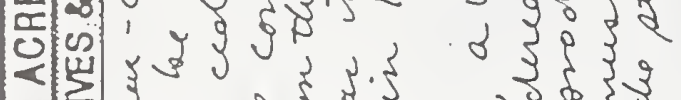

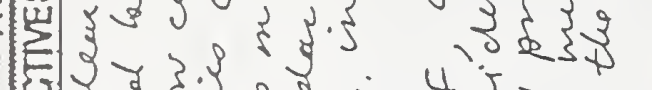

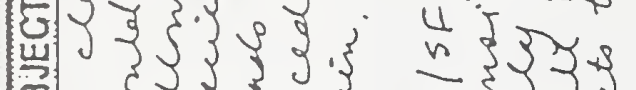

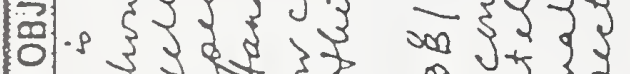

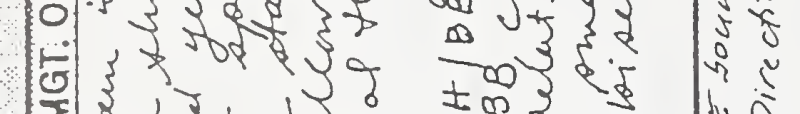

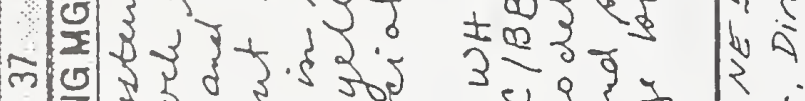

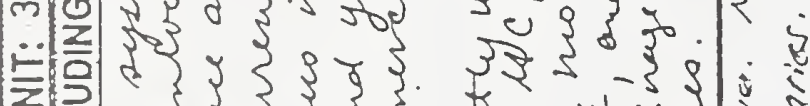

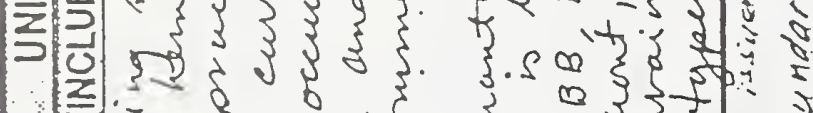

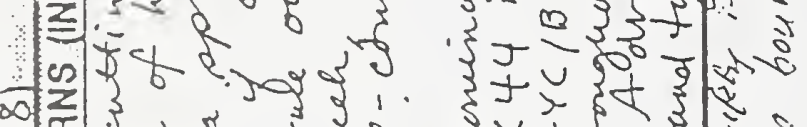

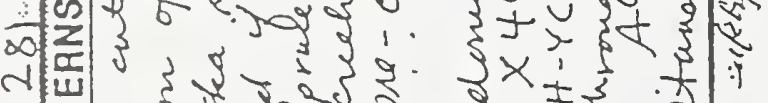

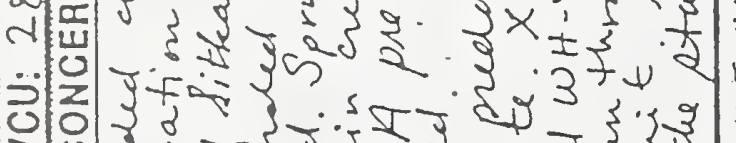

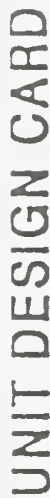

$=0.0003$

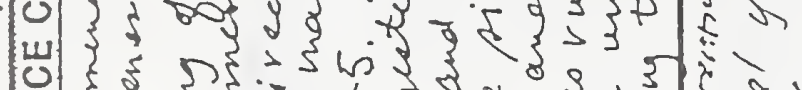

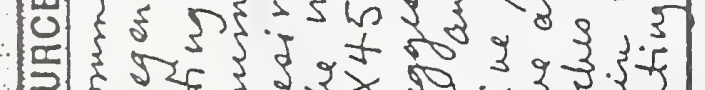

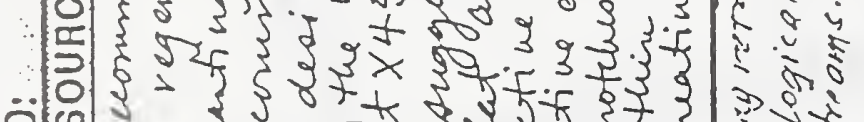
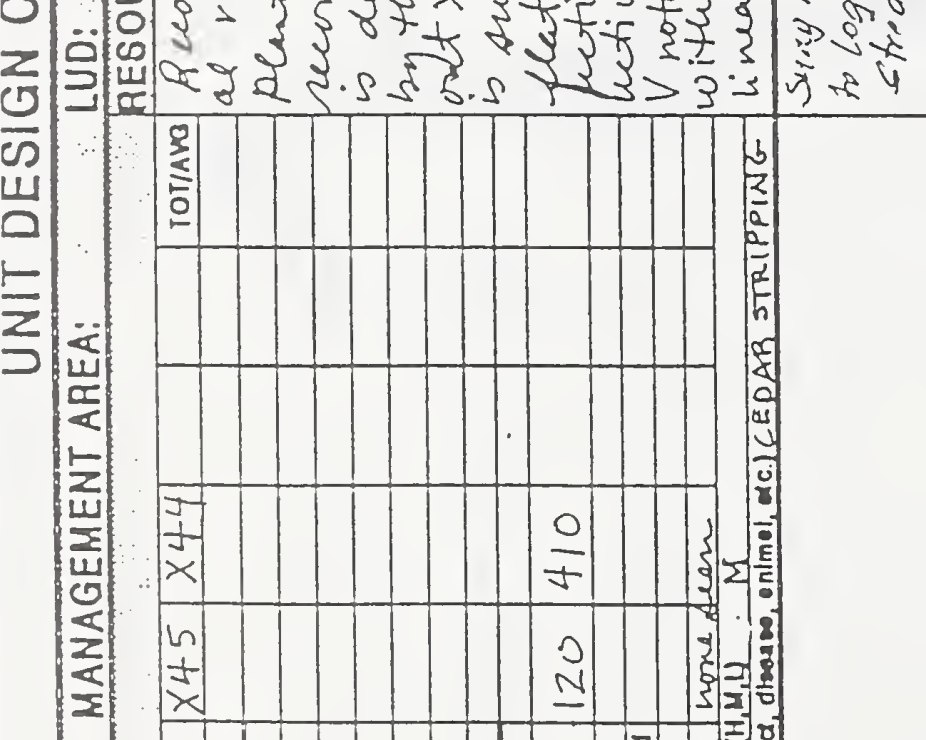

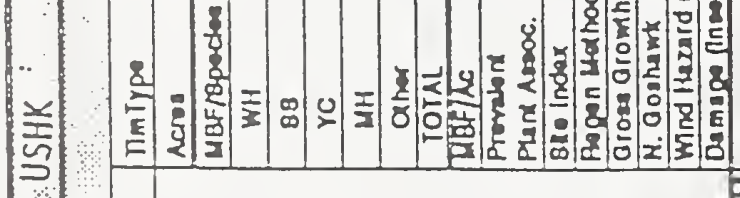

\section{s}

$x_{i=2}$
8

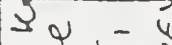

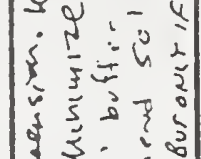

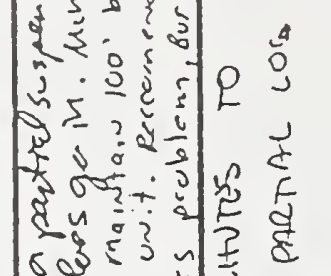

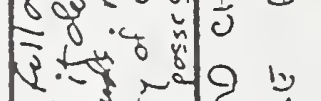

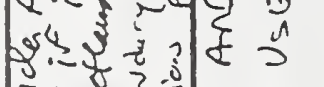

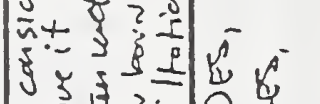

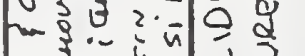

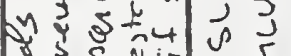

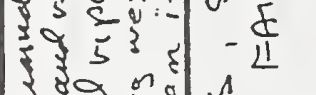

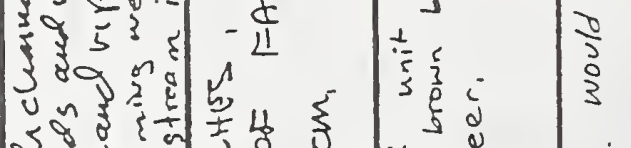

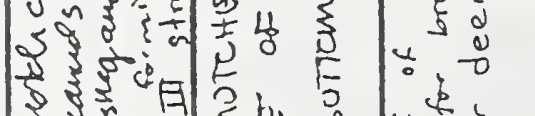

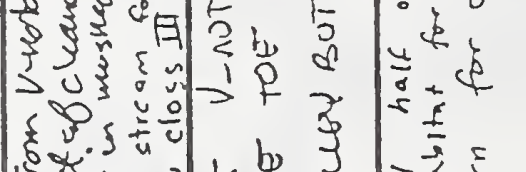

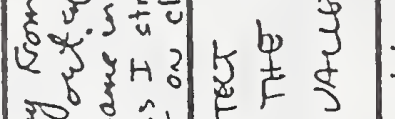

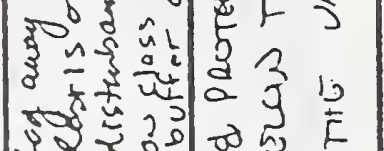




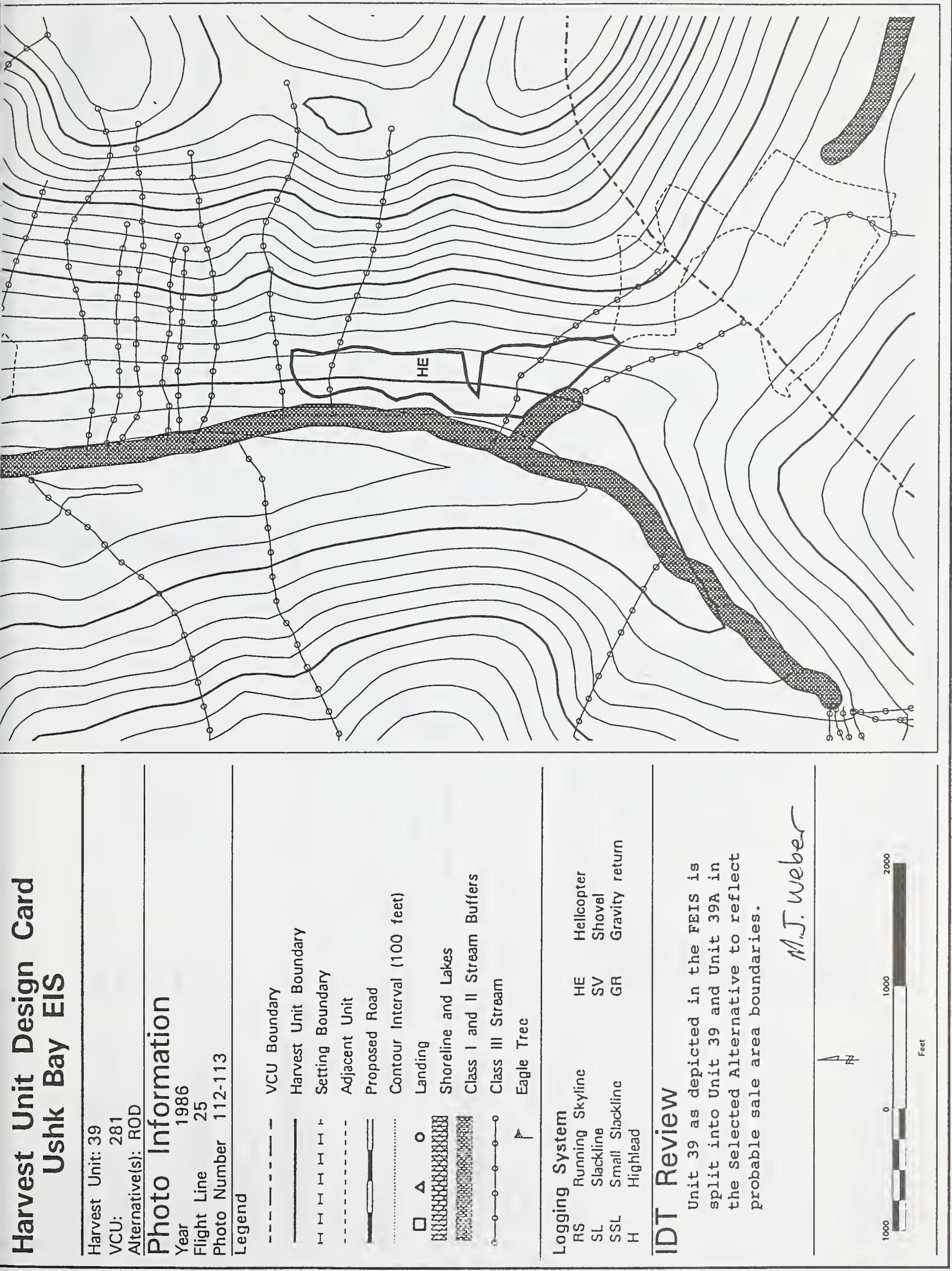




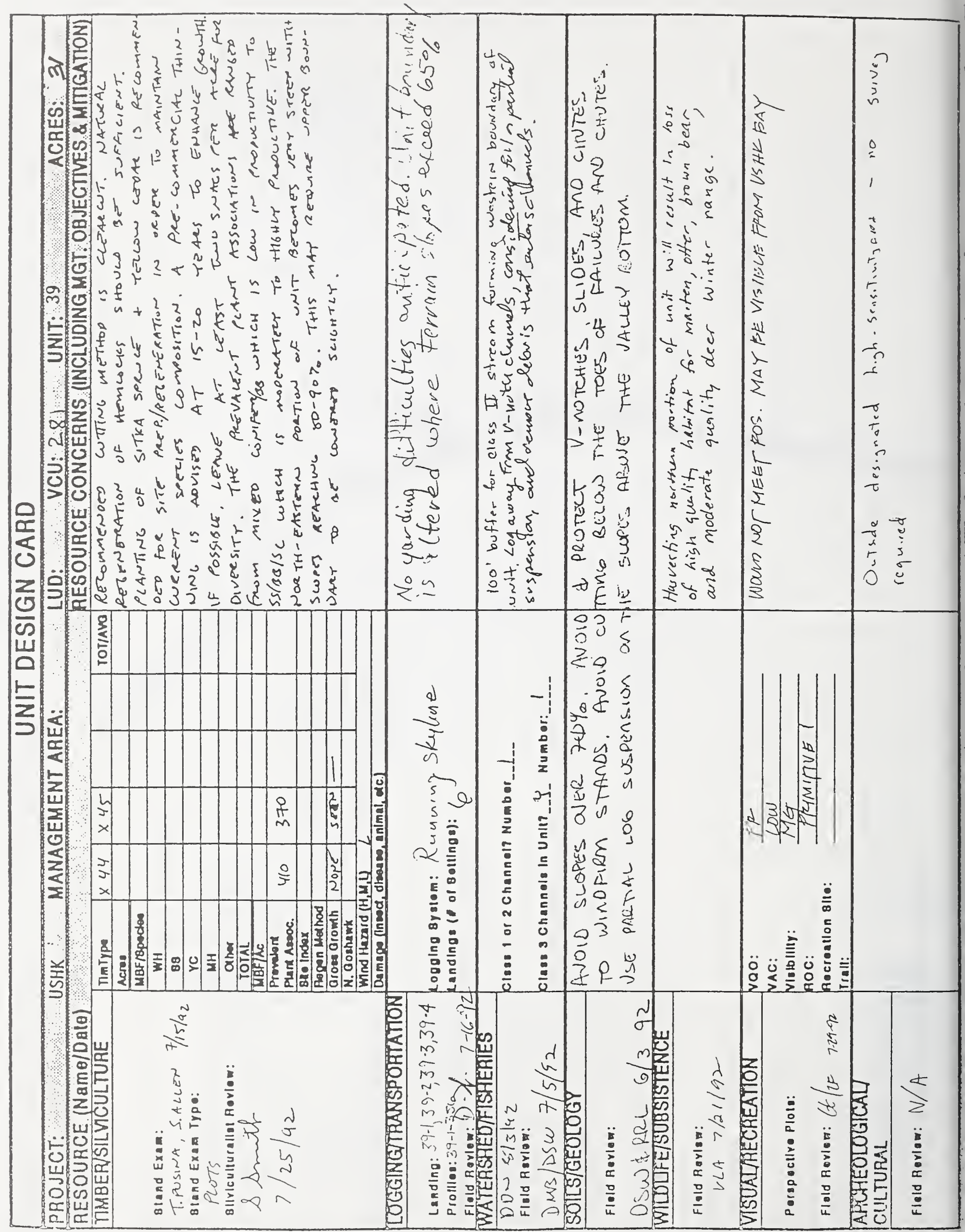



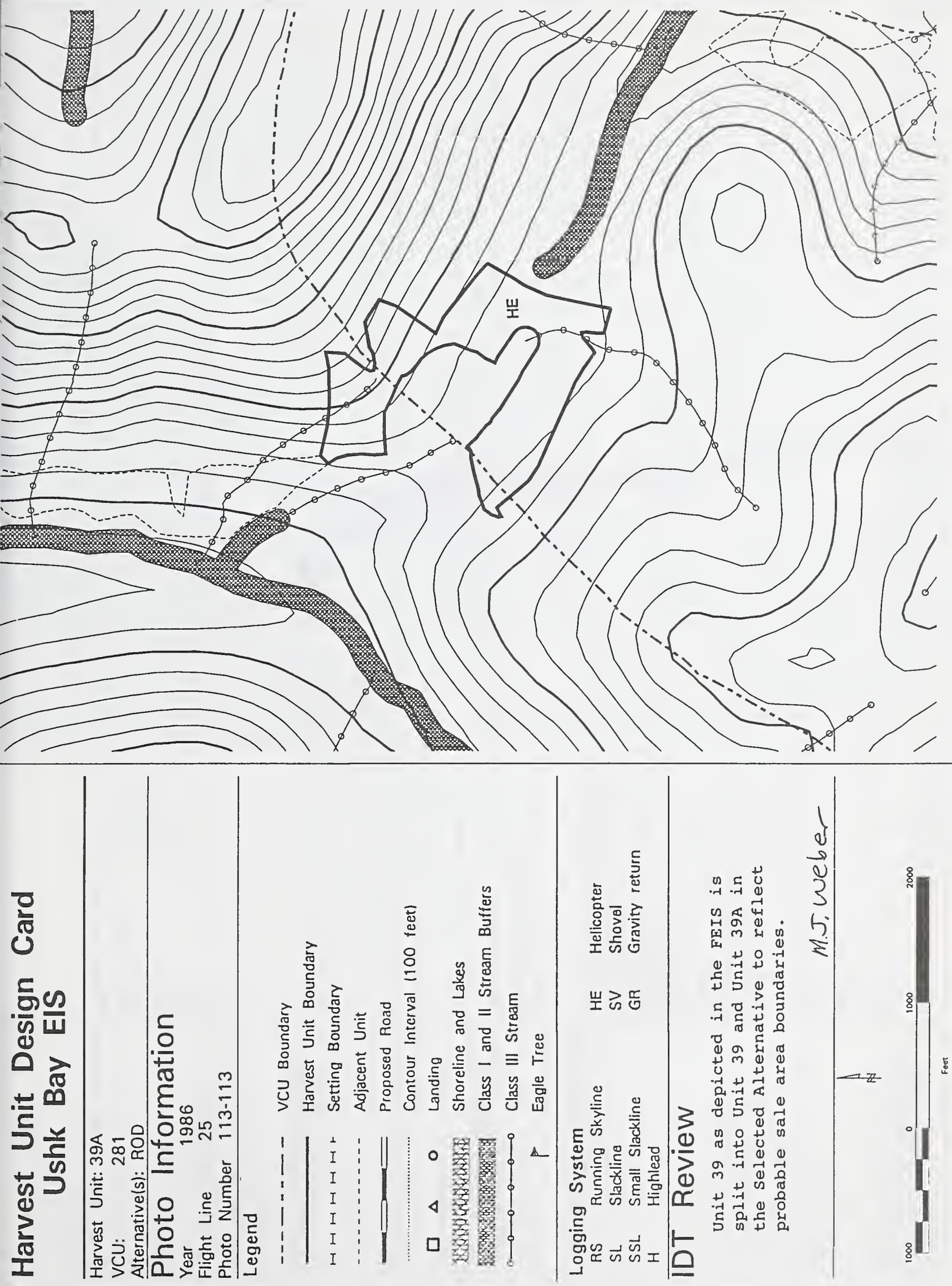


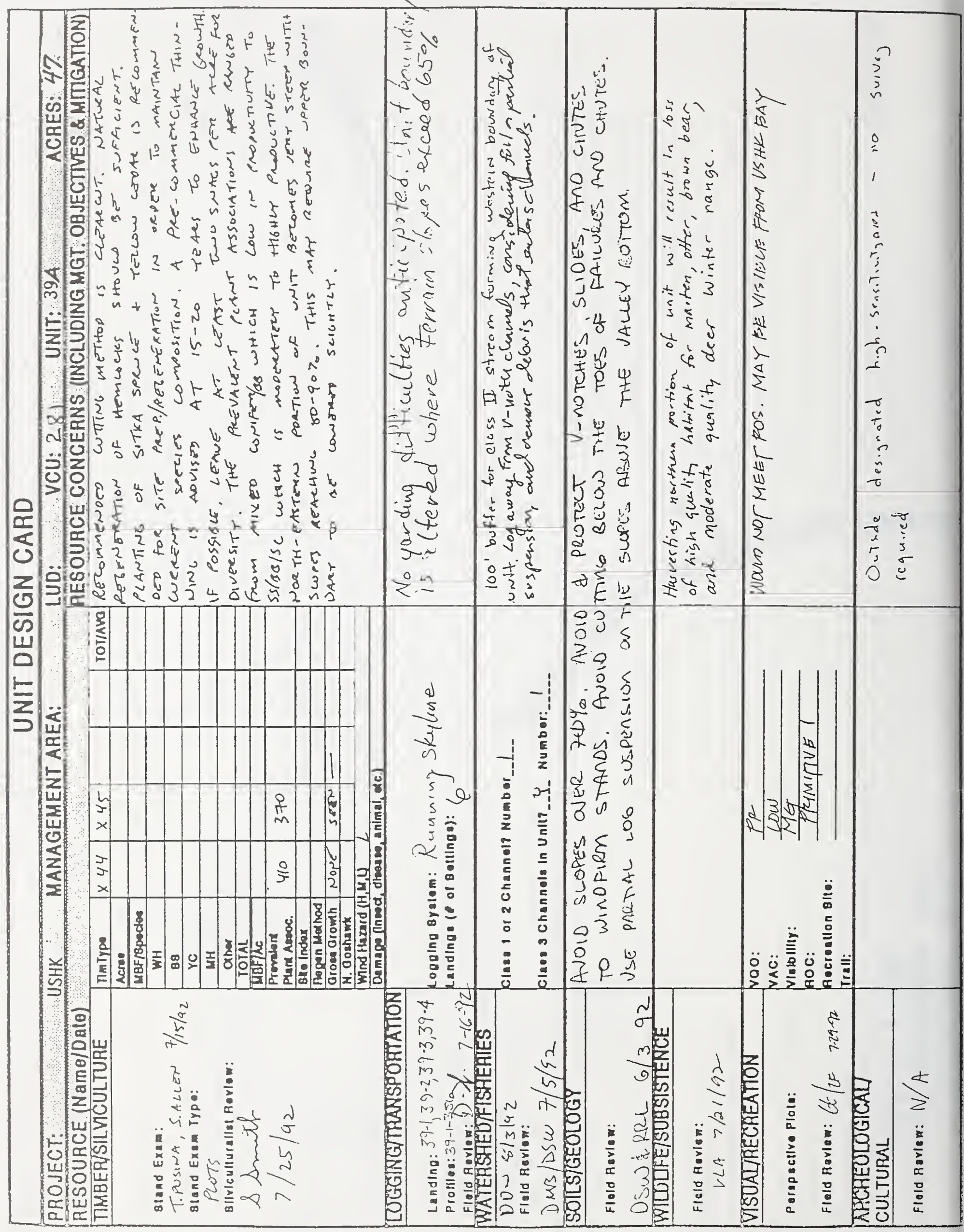




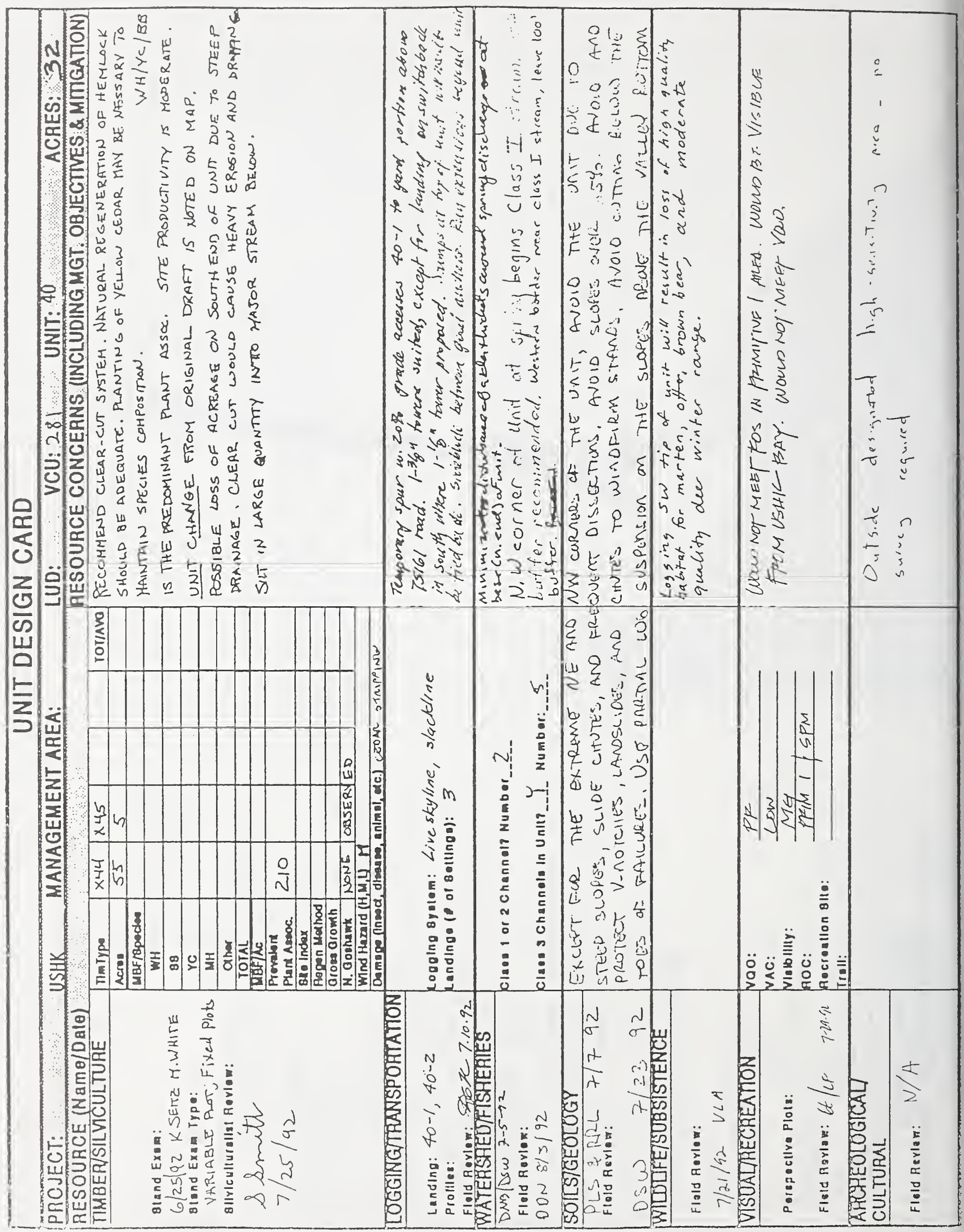




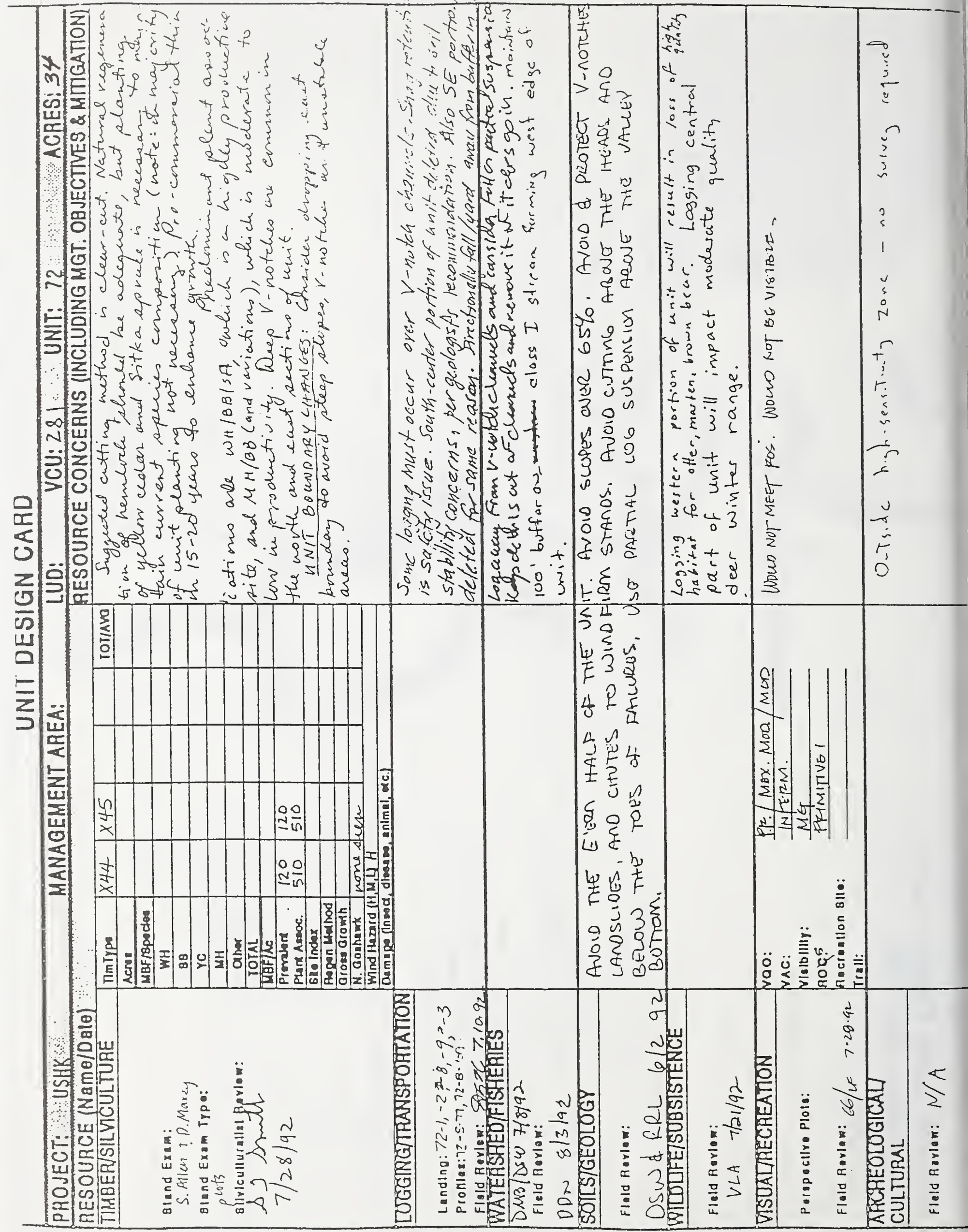




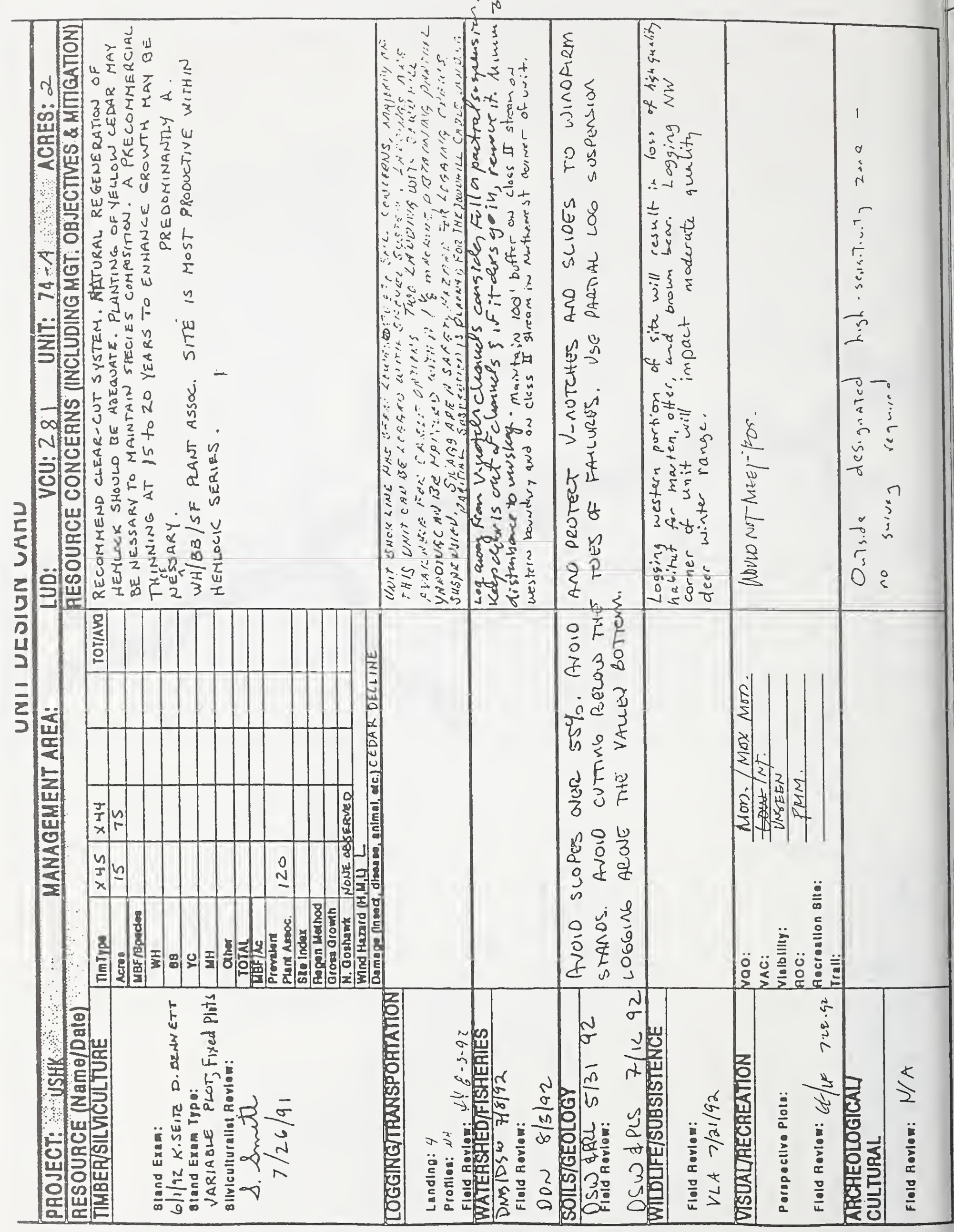




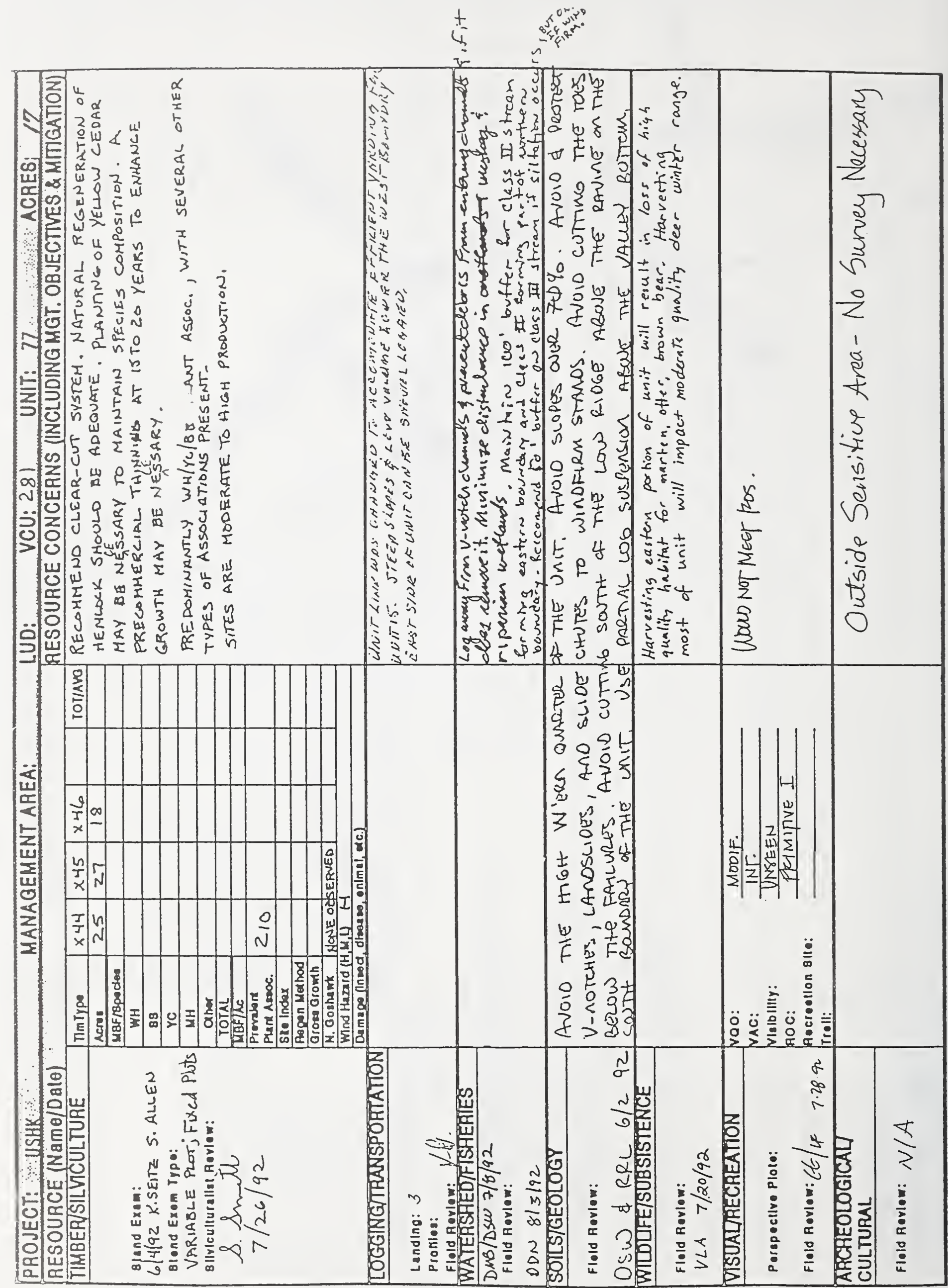




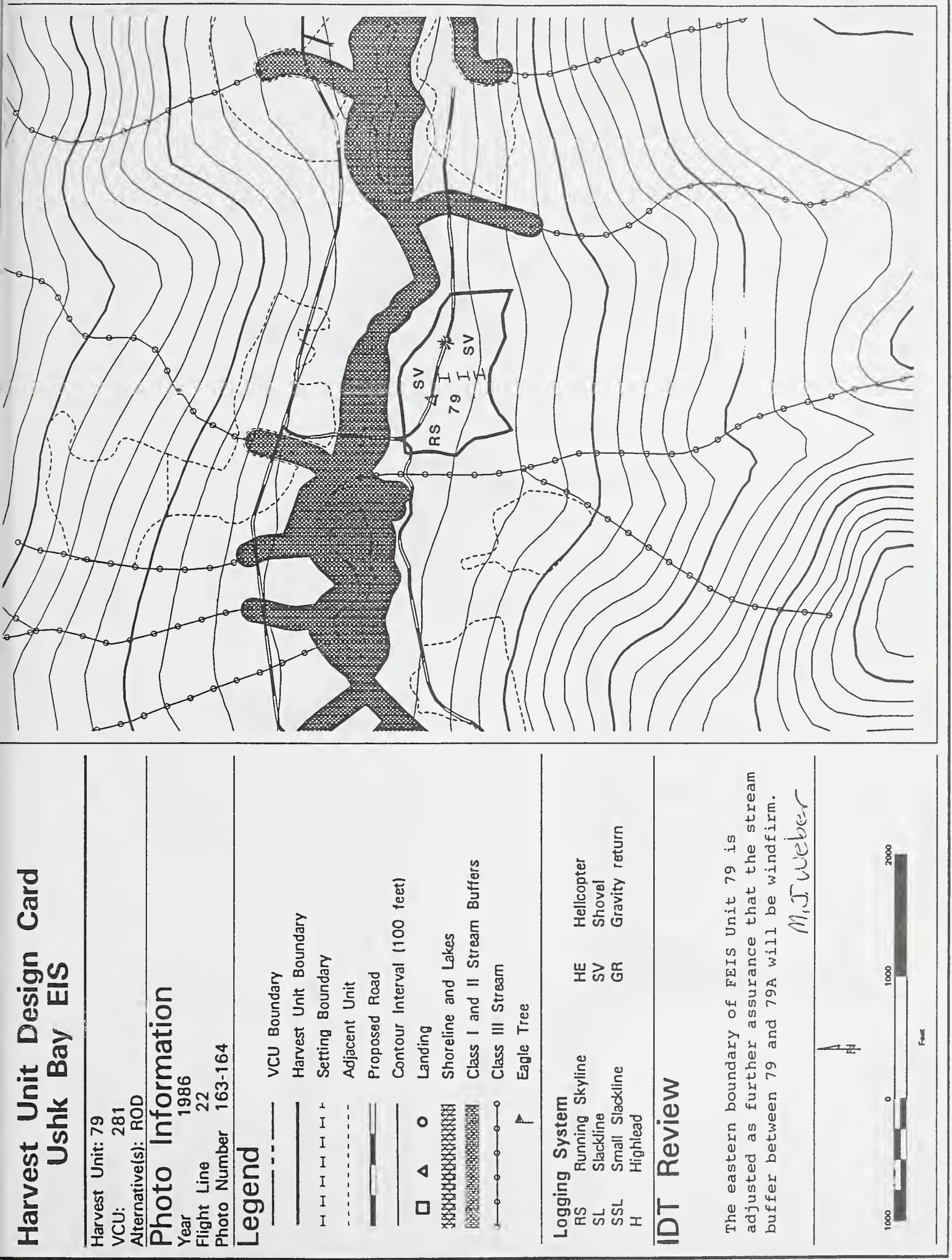




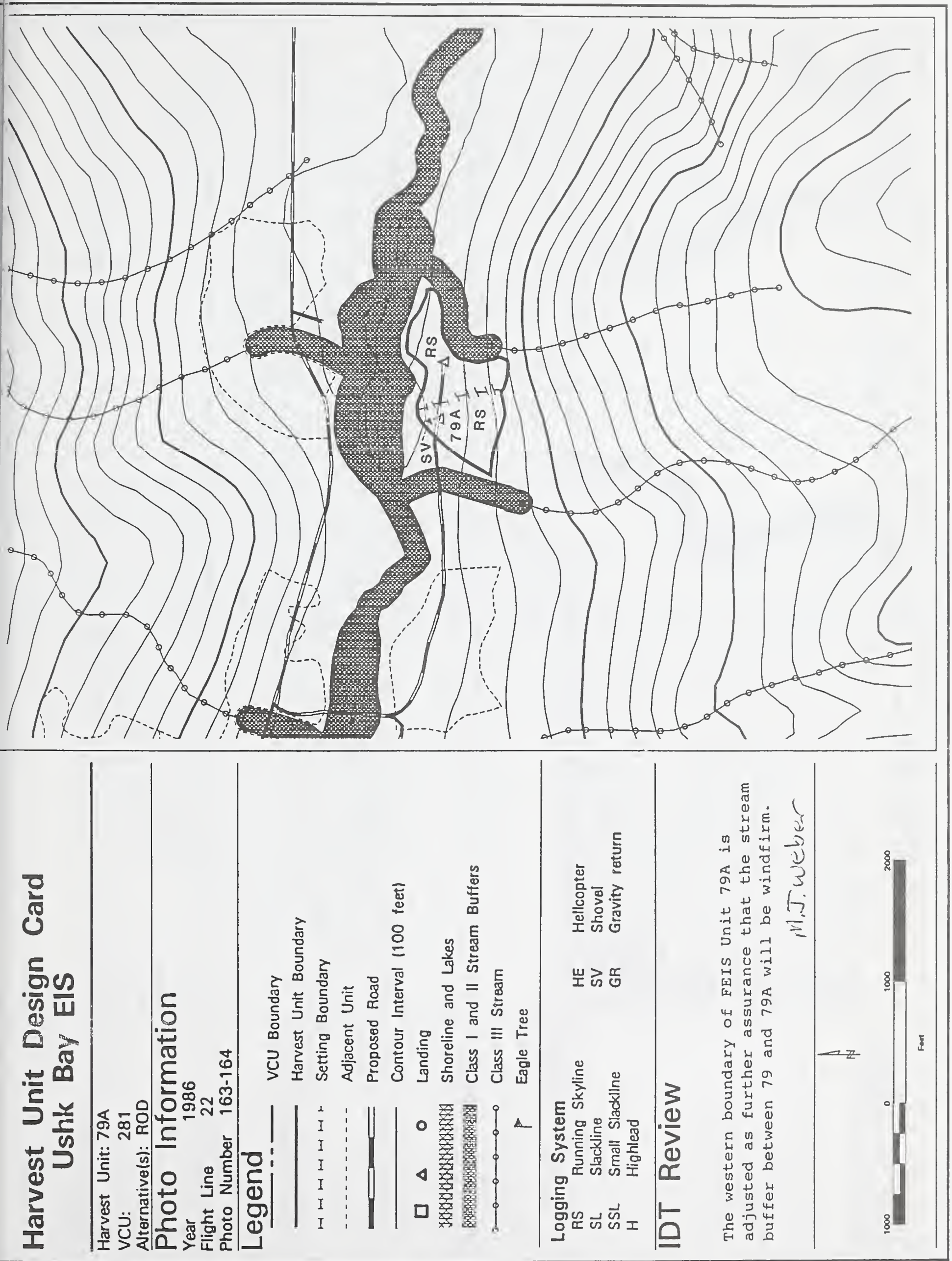




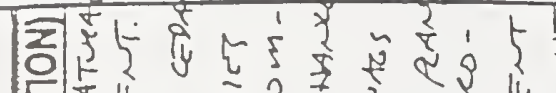

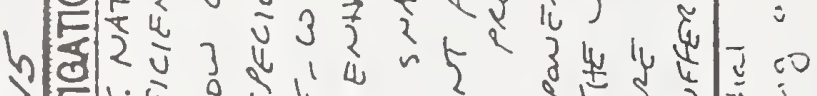

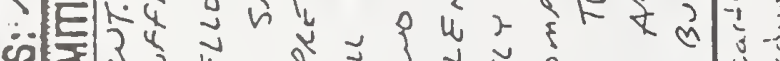

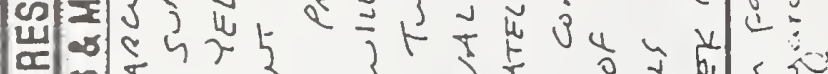
위욜

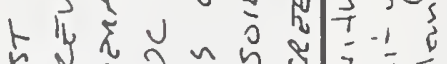

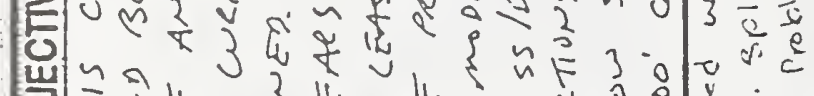

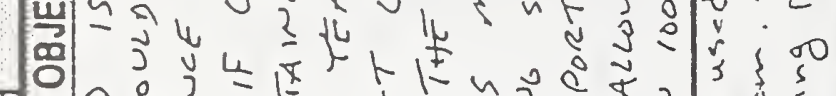

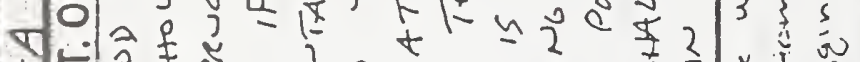

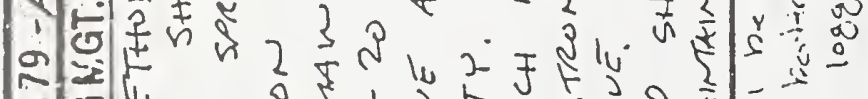

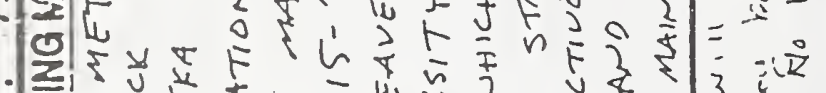

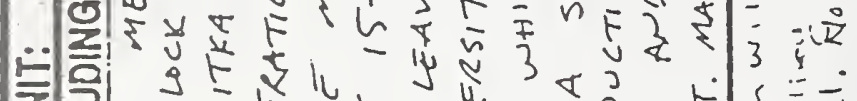

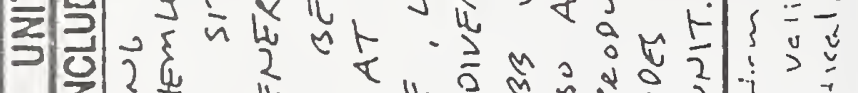

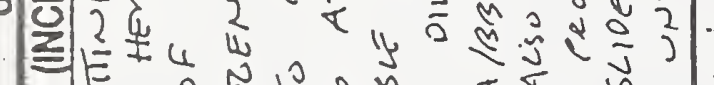
की

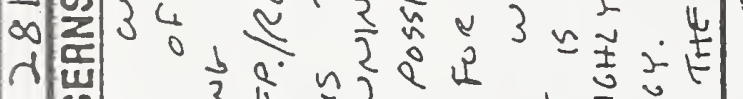

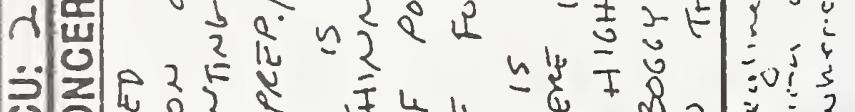

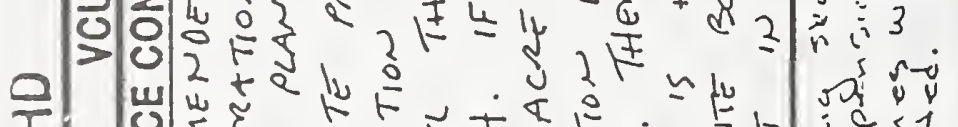

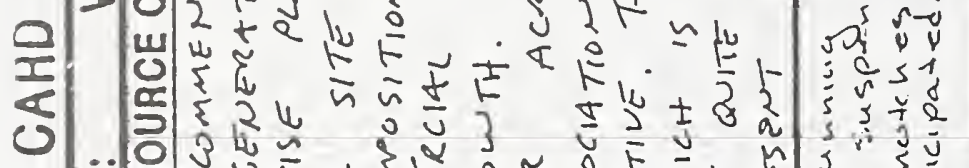

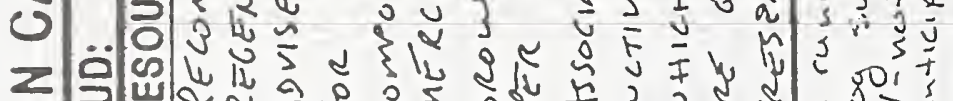

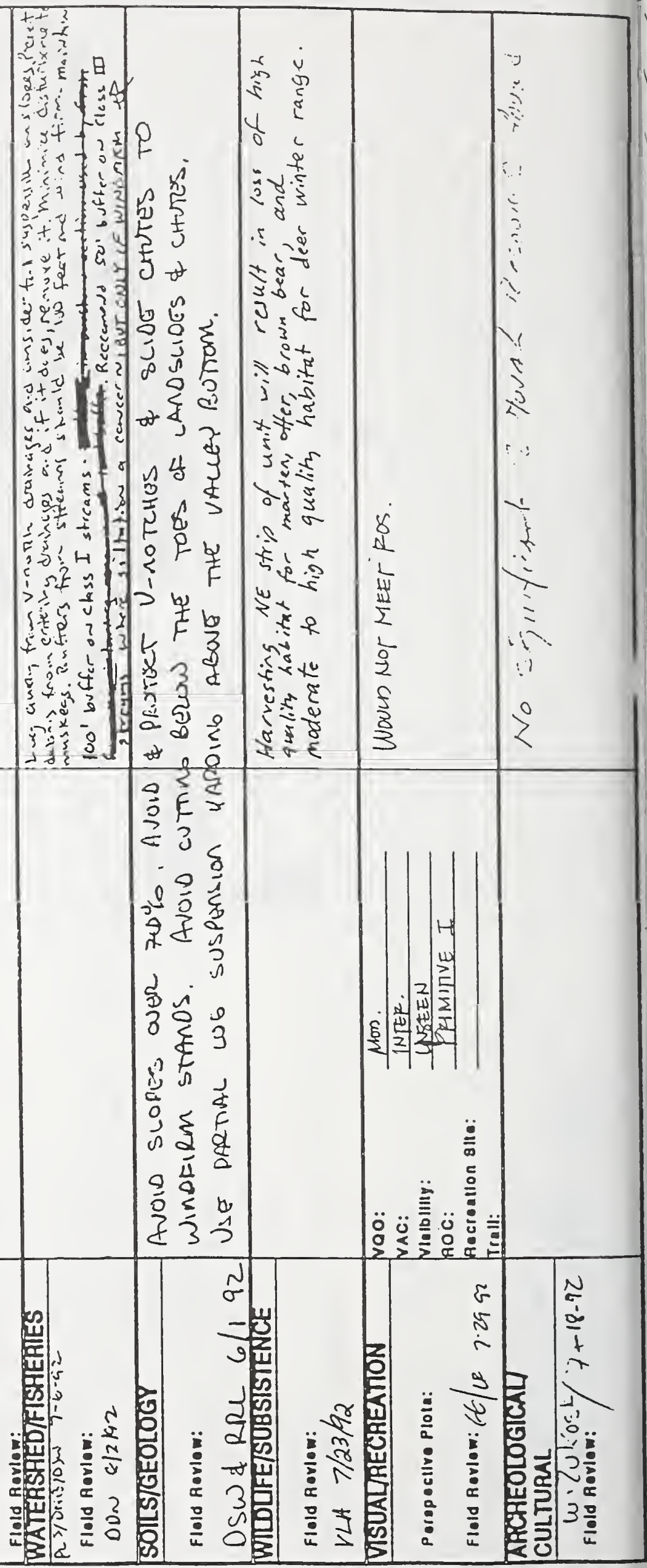




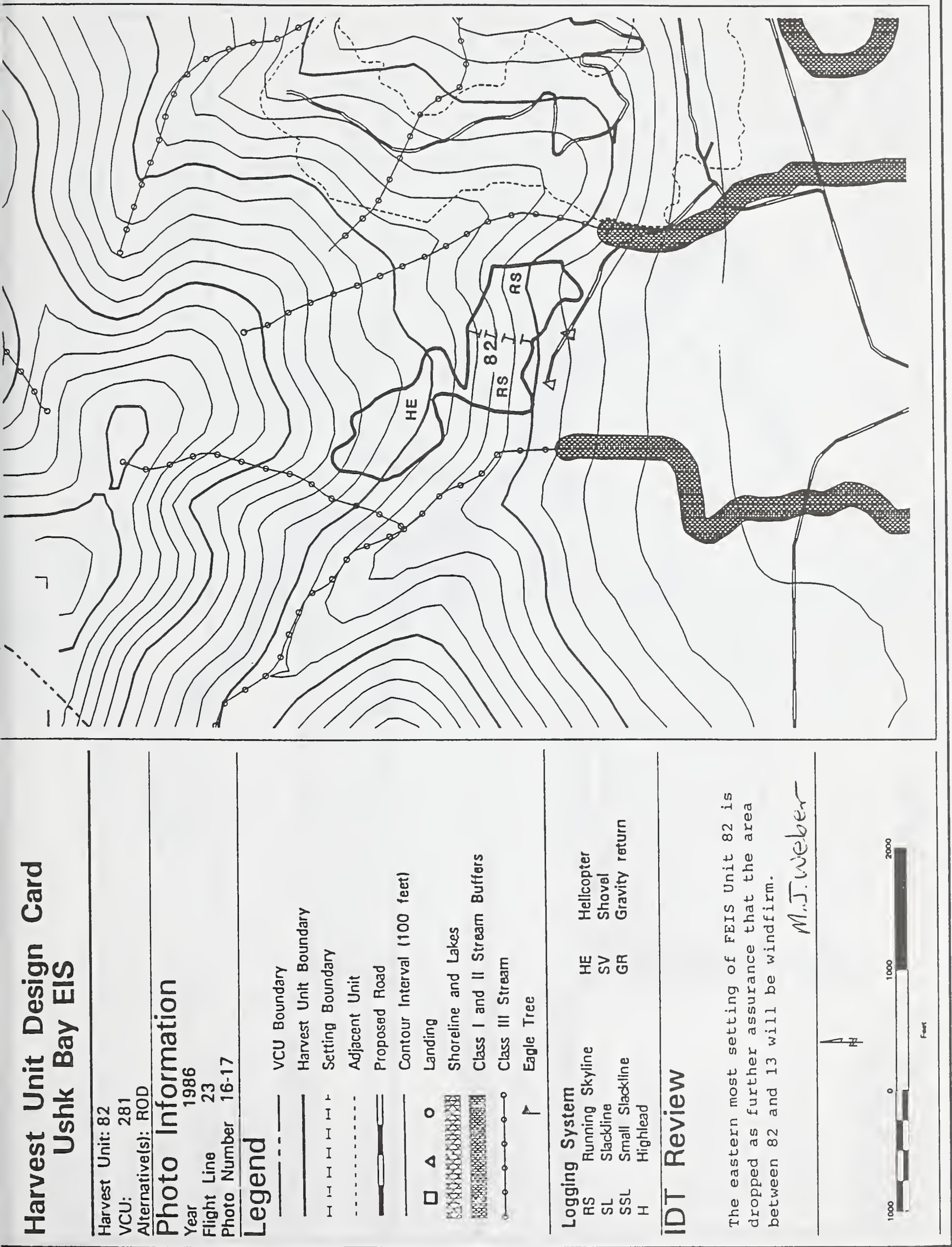




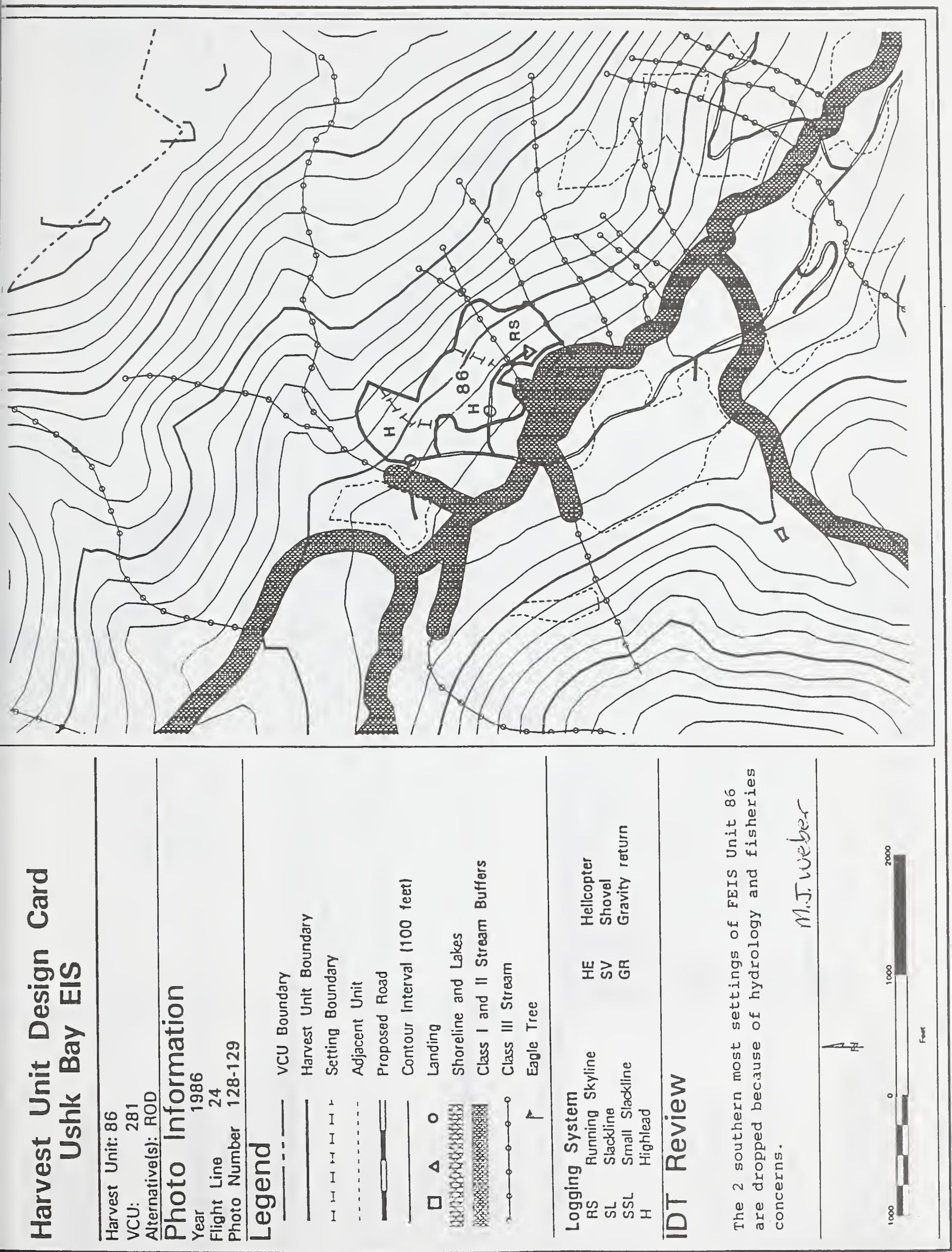




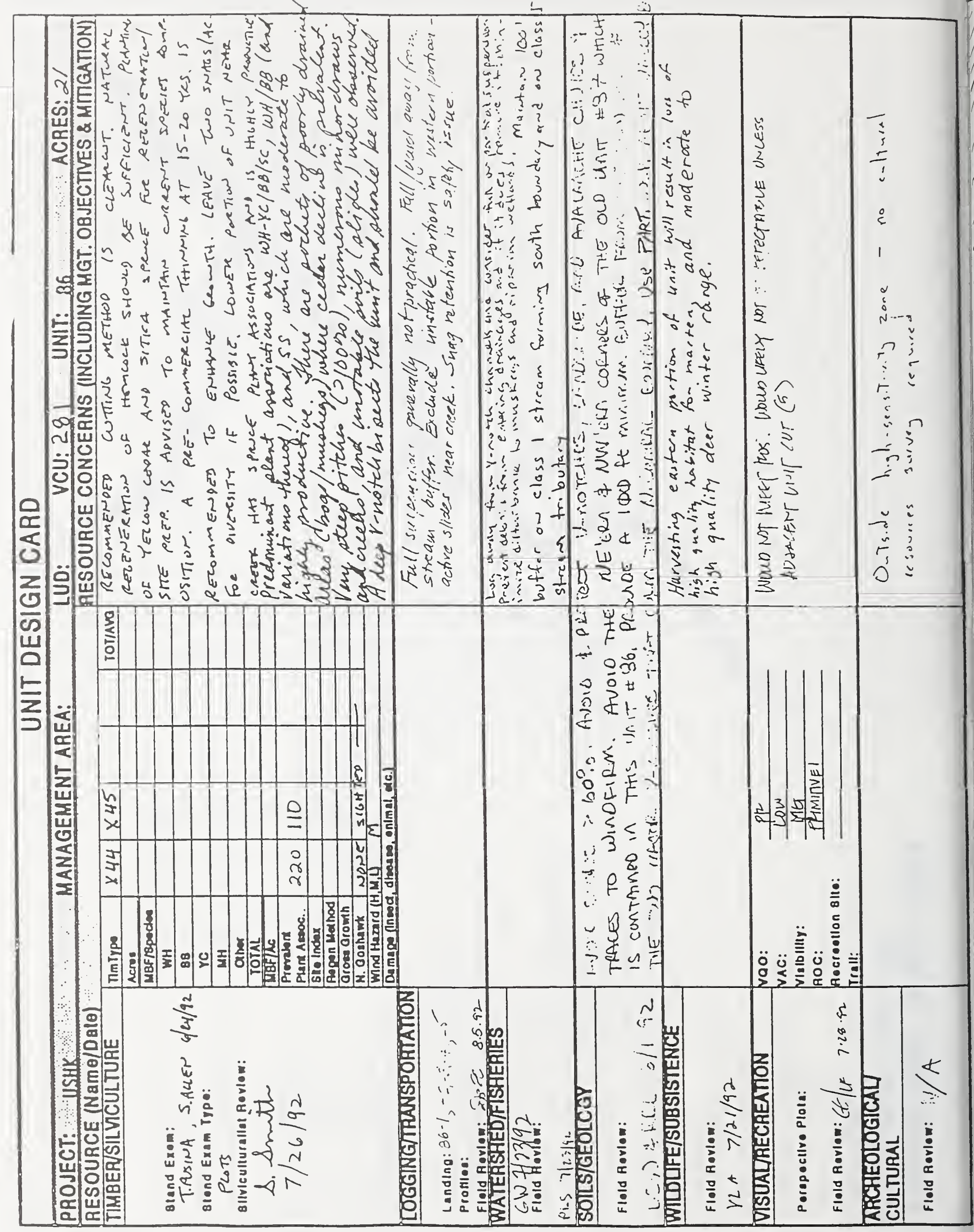




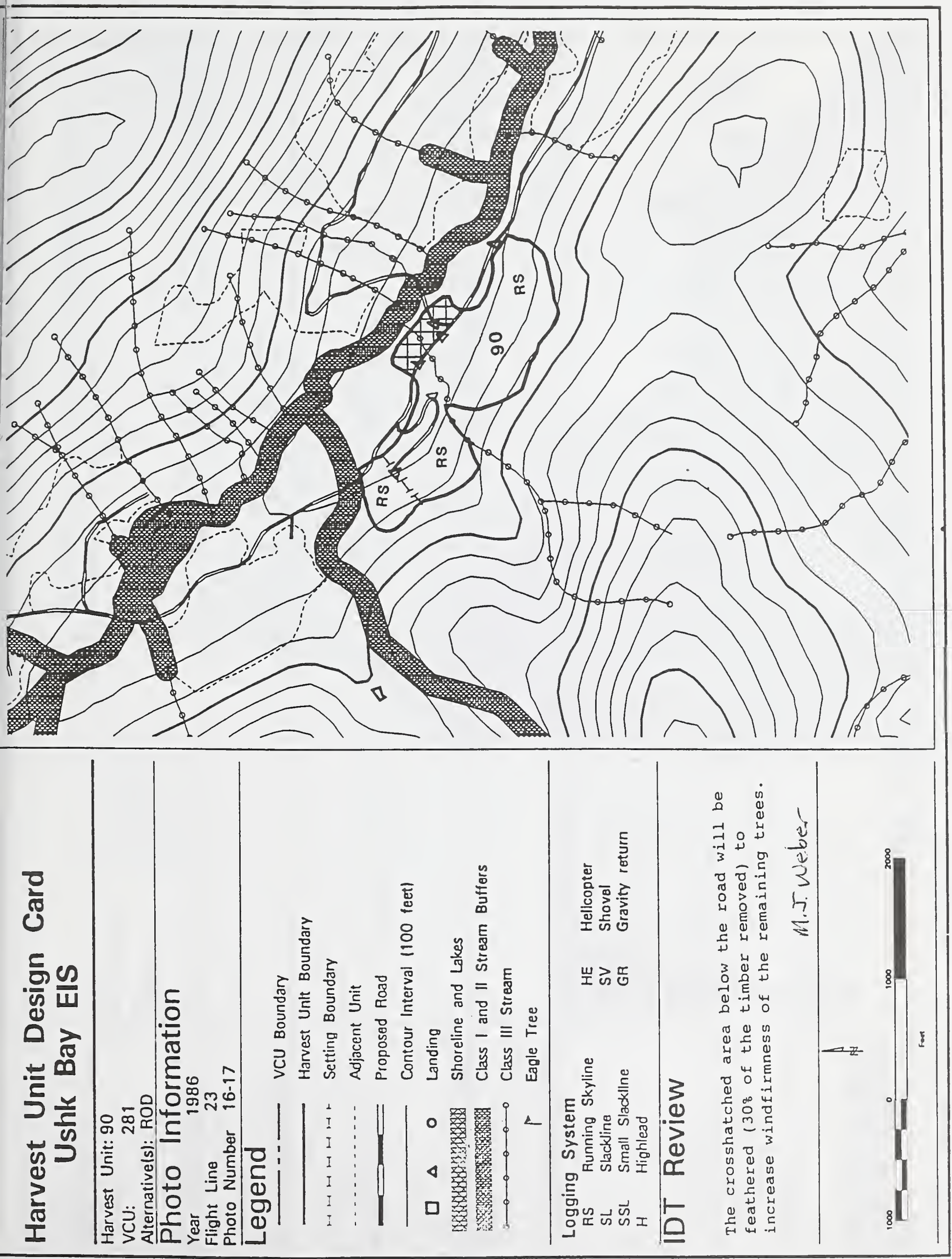




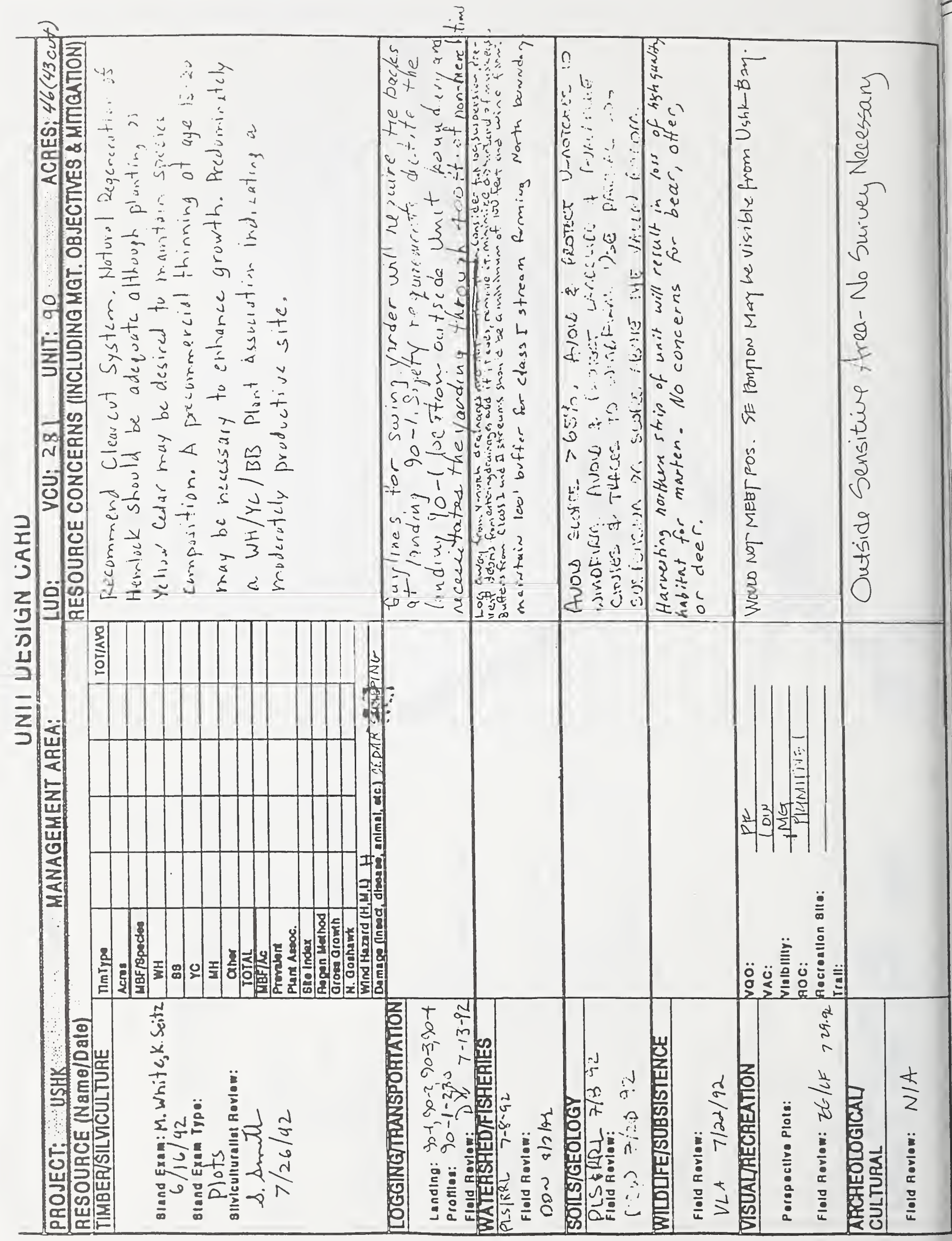



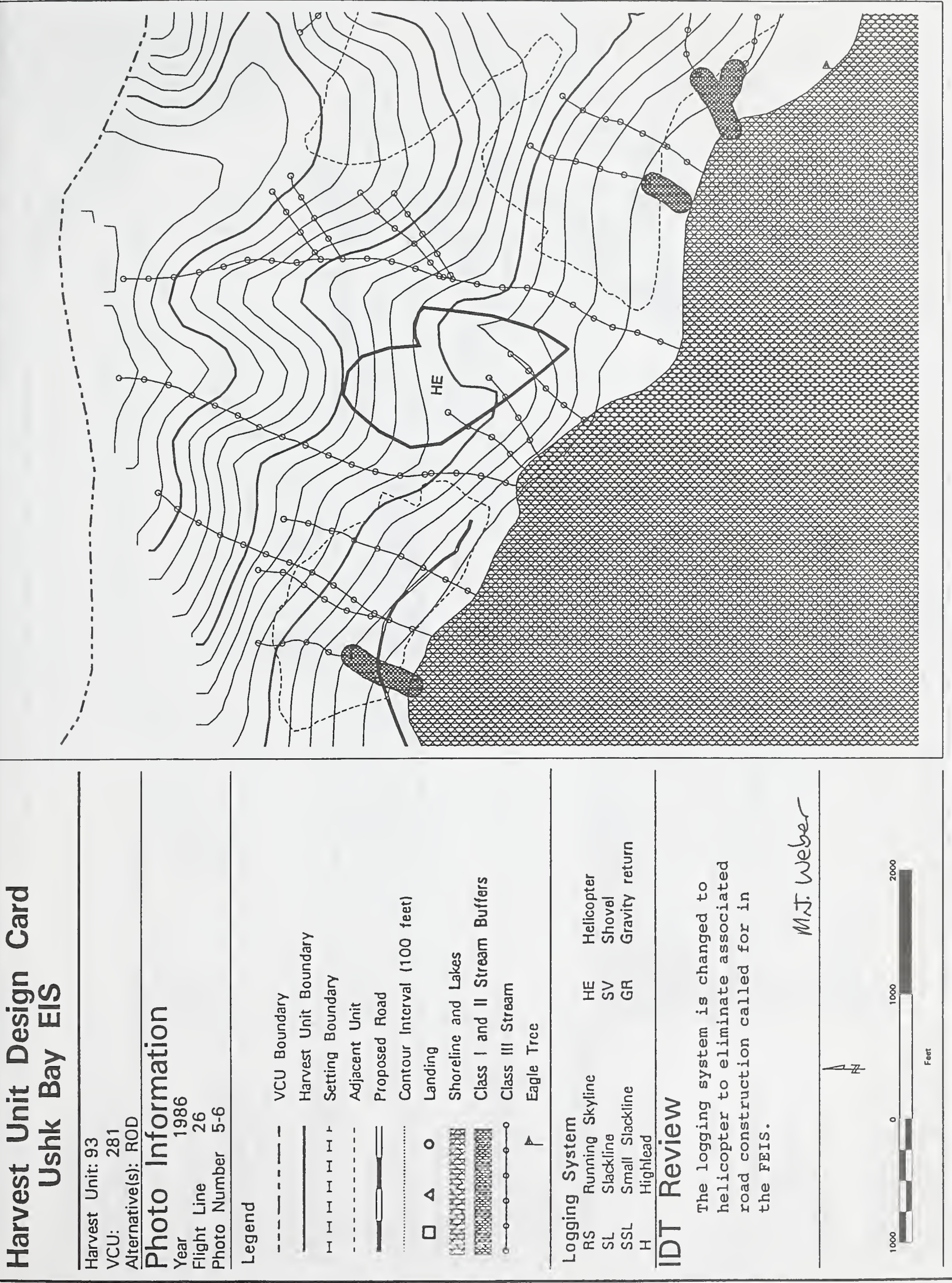

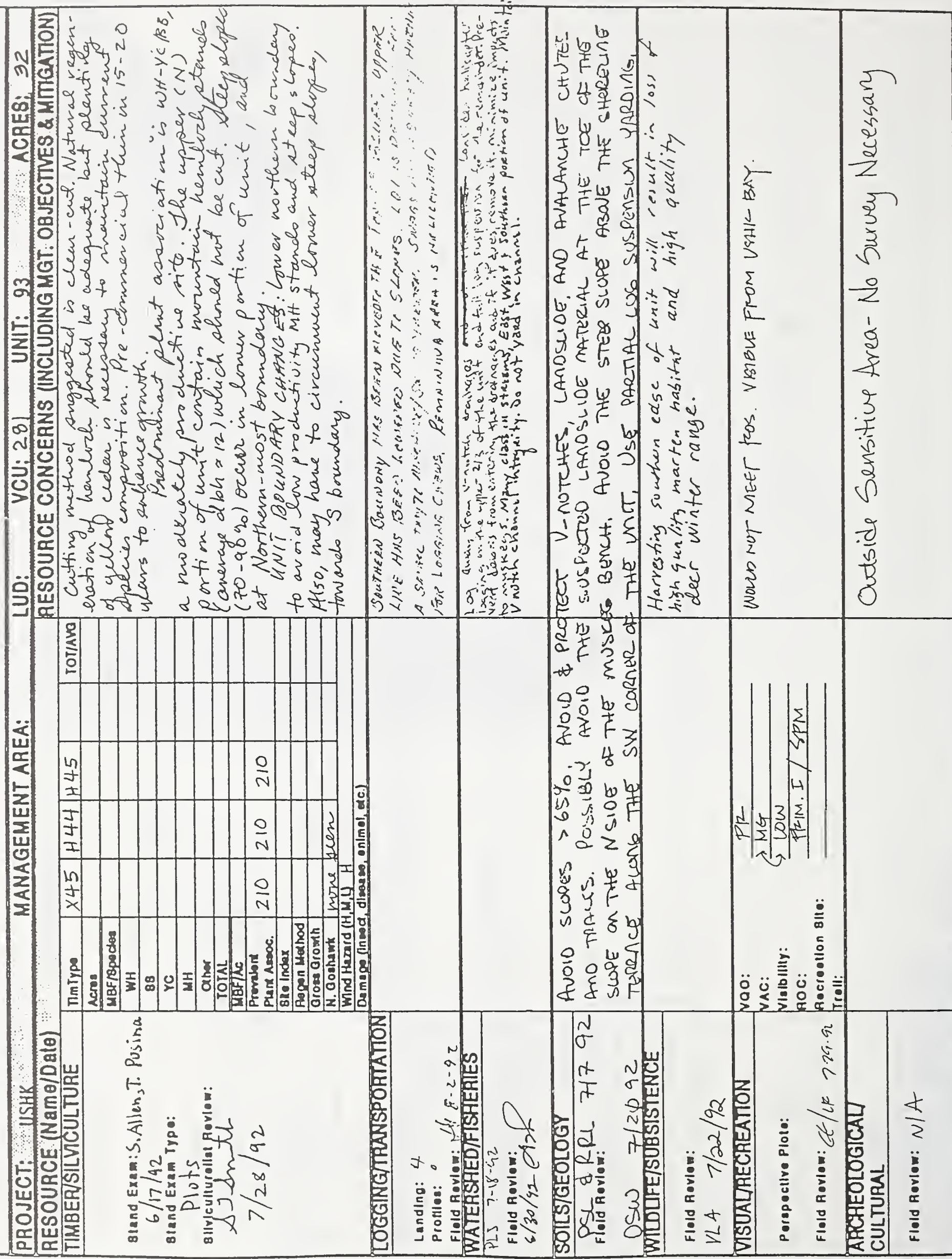

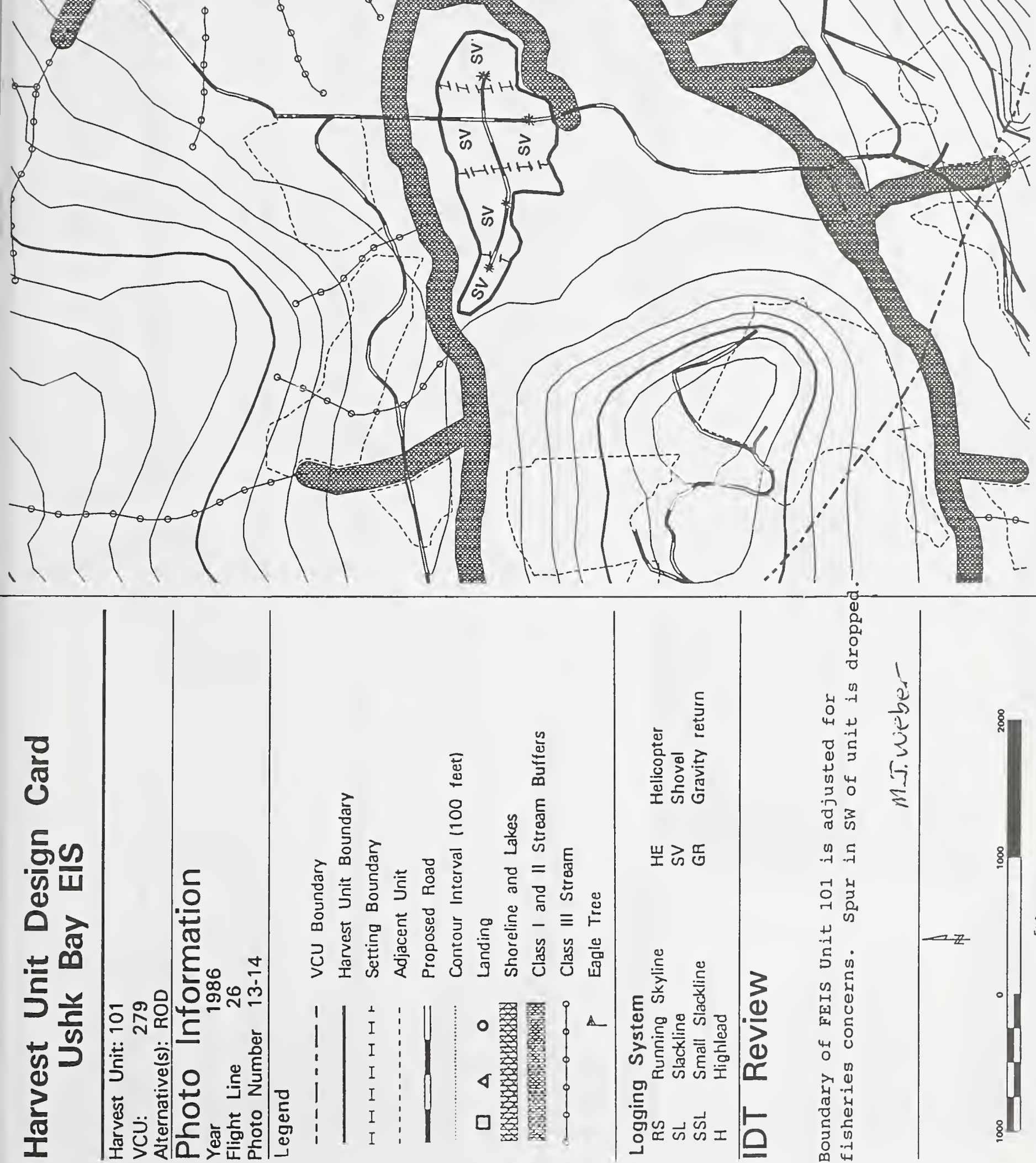

는

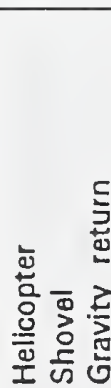

$\begin{array}{lll}\overline{0} & =\mathrm{I}\end{array}$
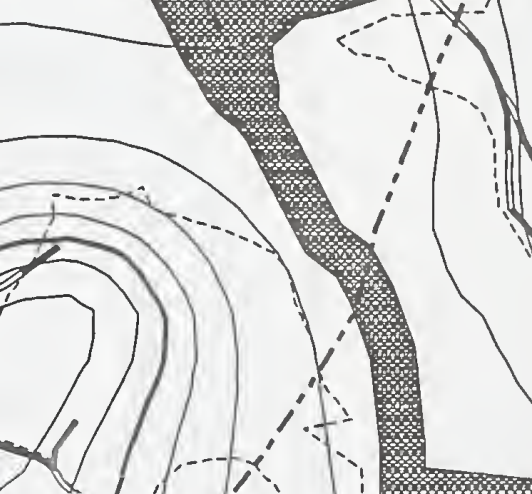

ᄃ

○ 5 व

(n)

.

-1

-

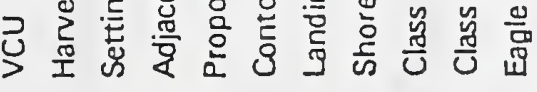

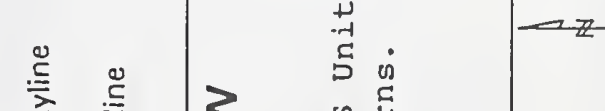
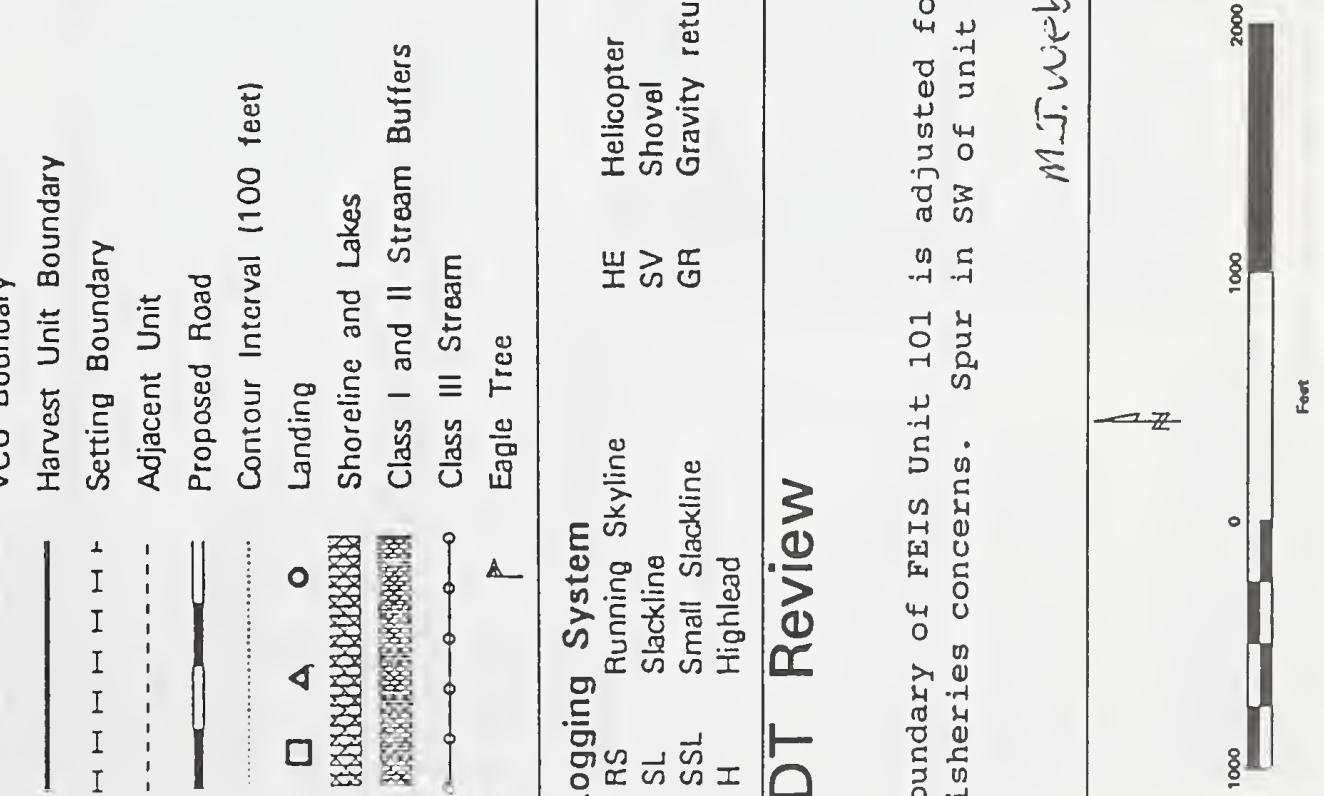

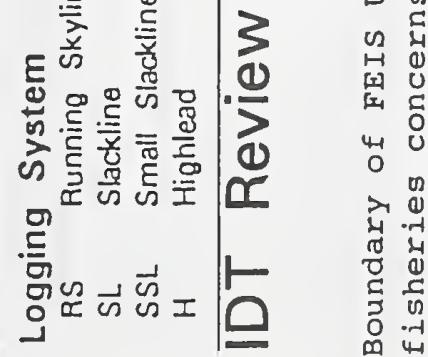




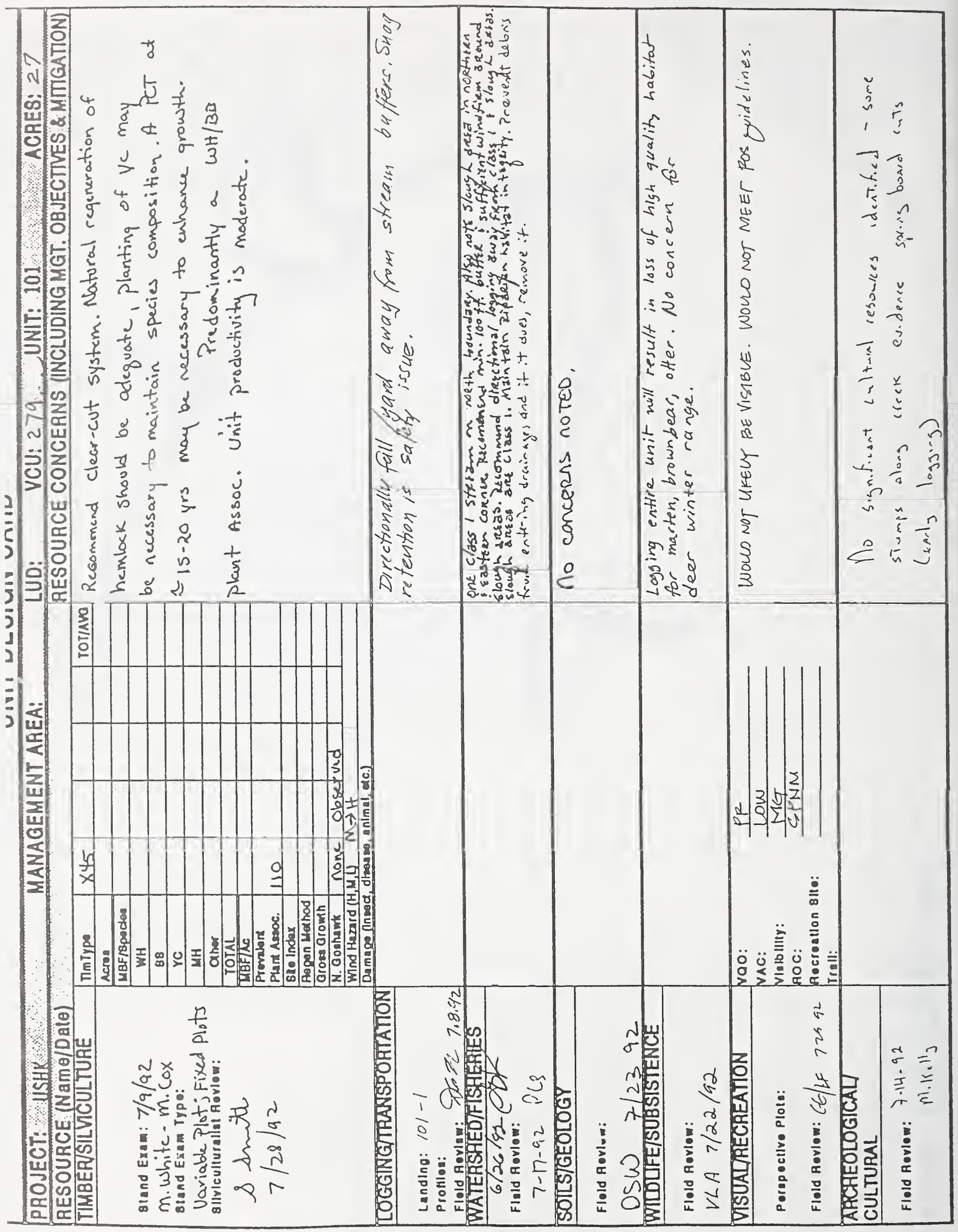




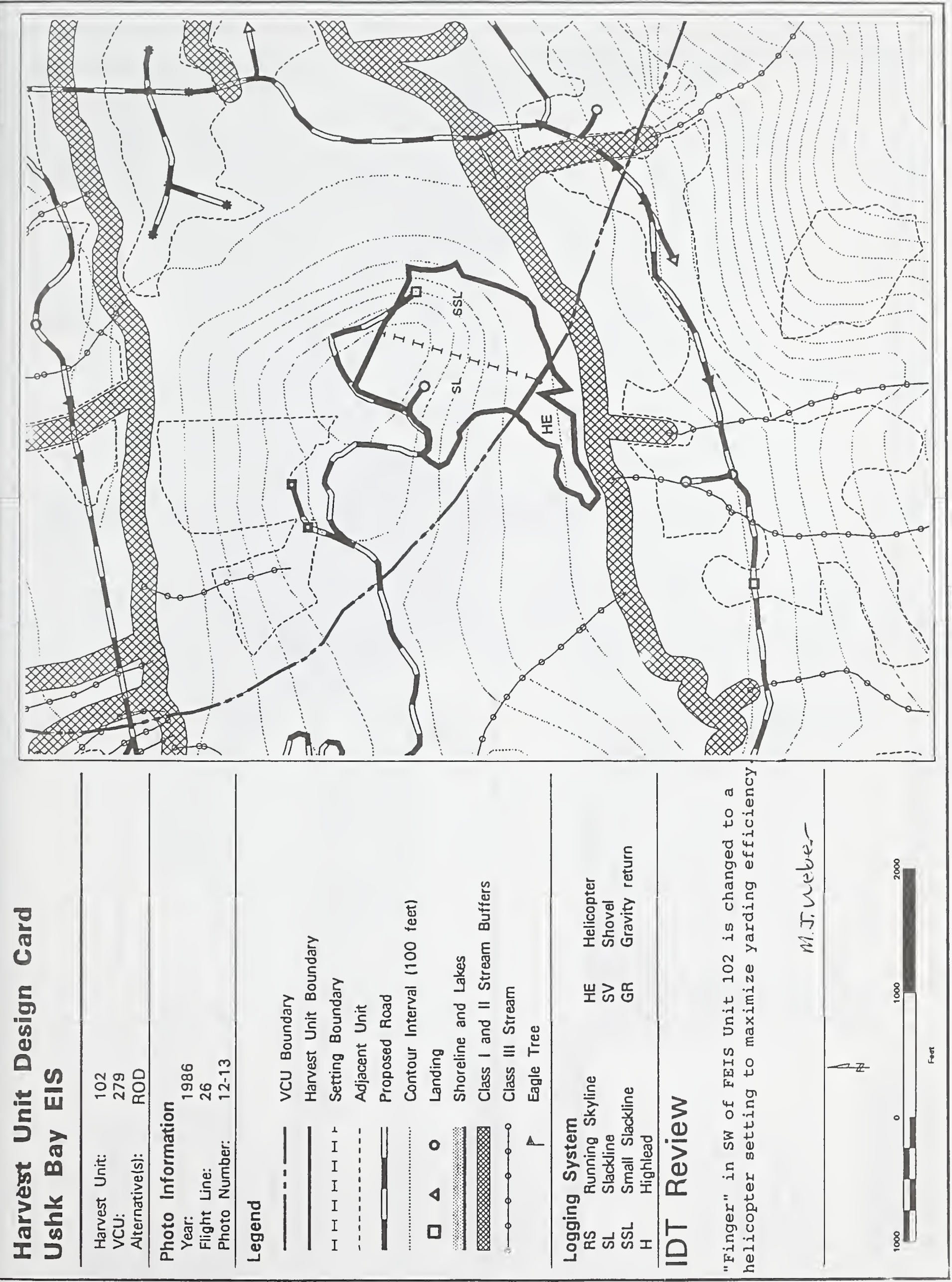




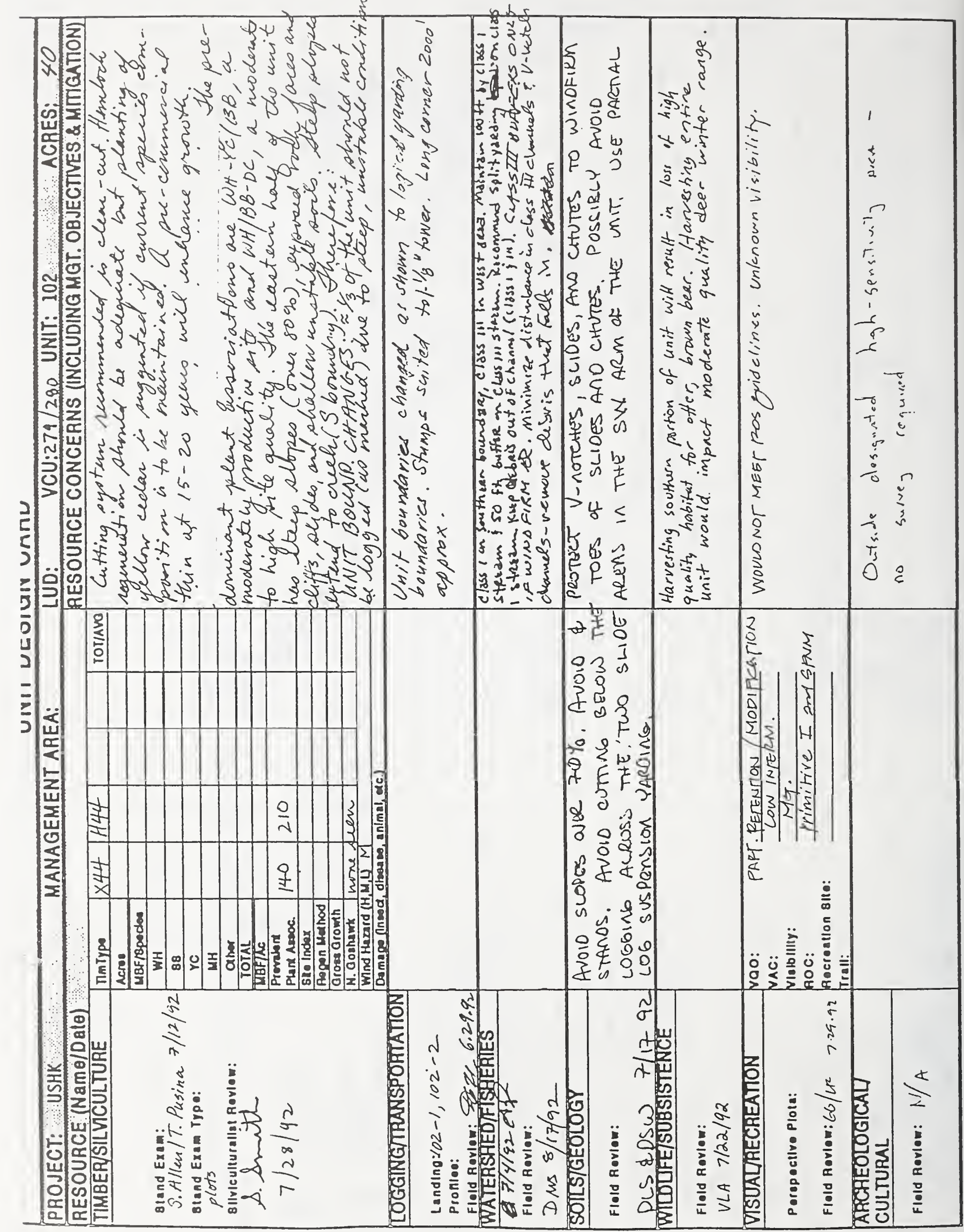




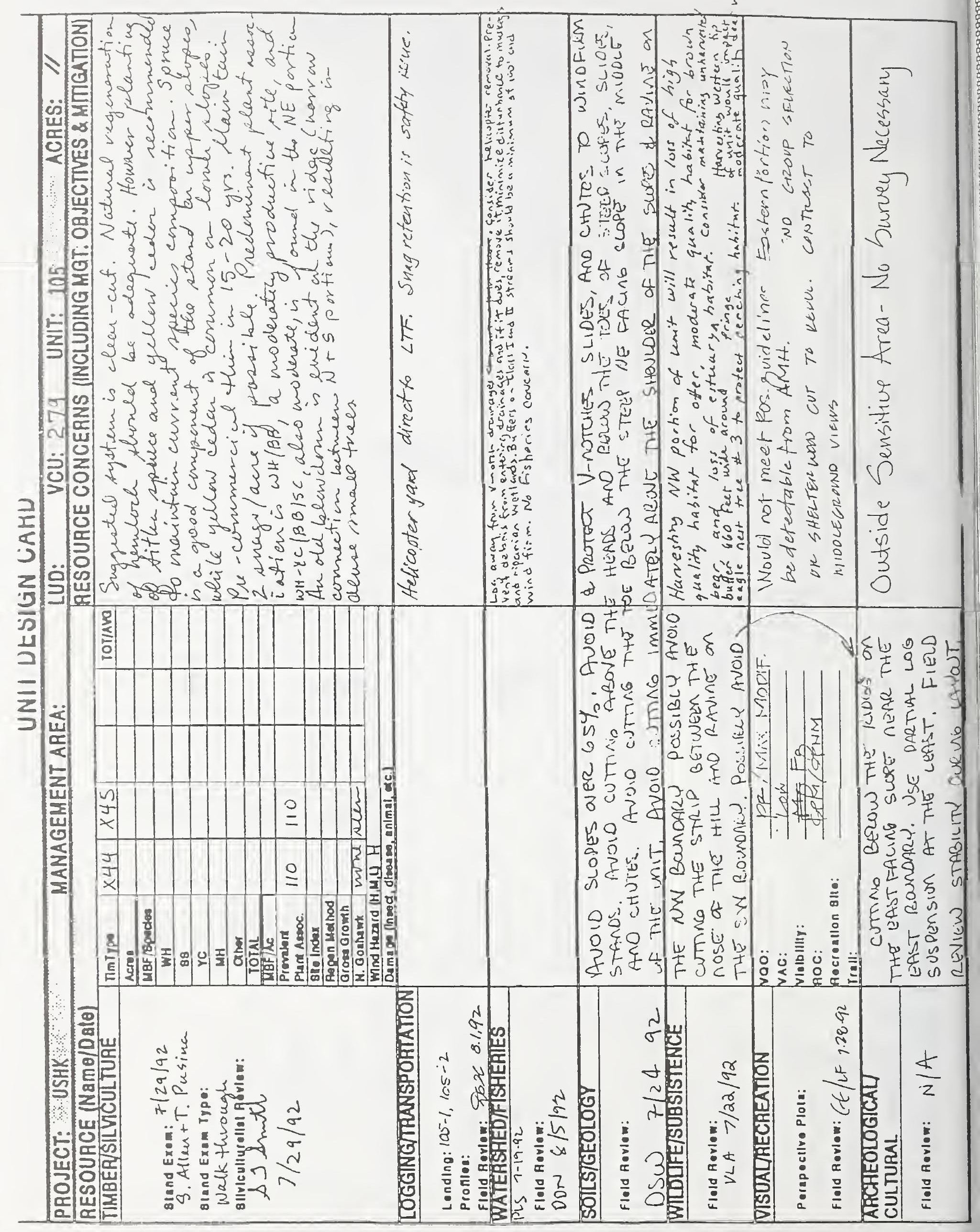




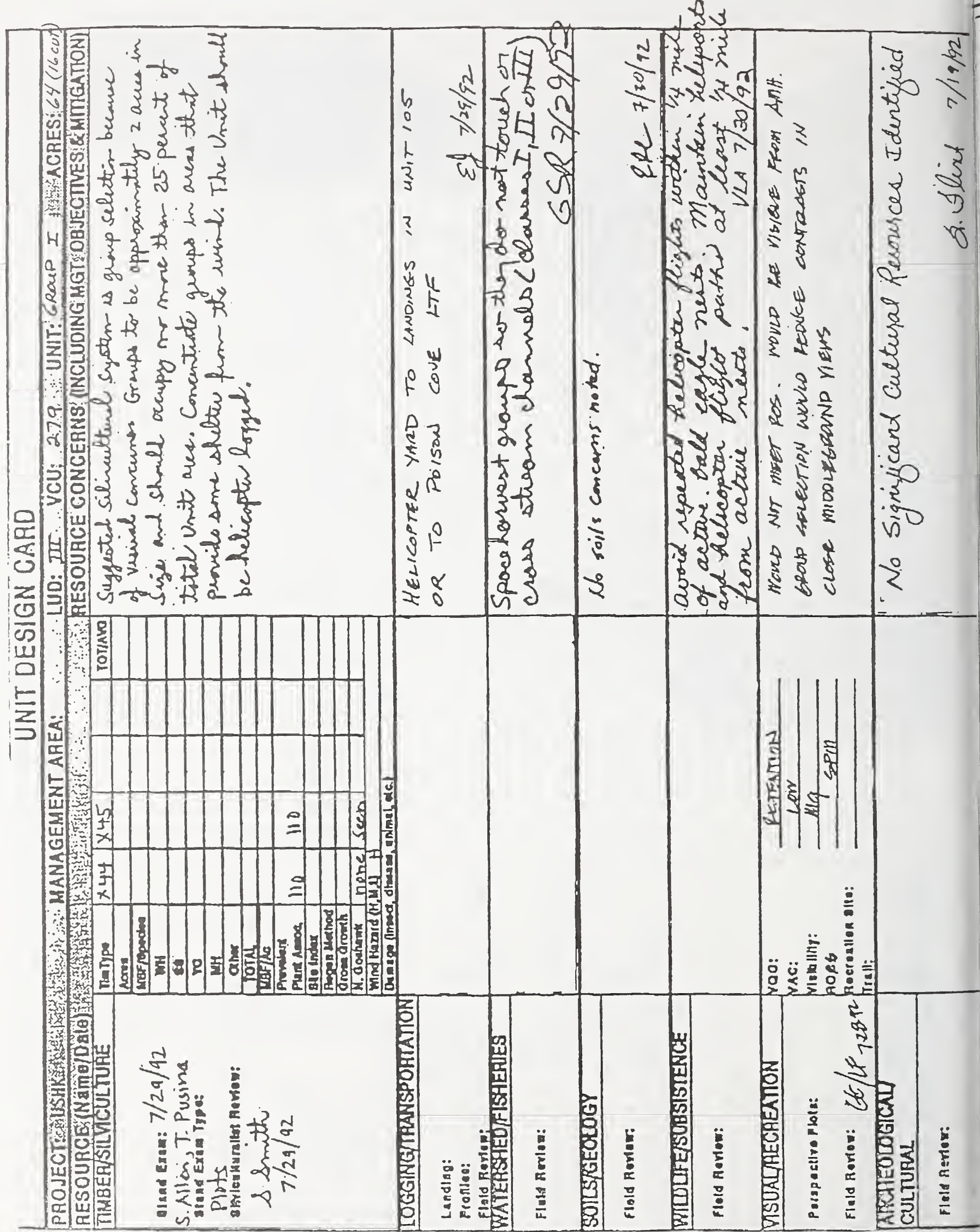




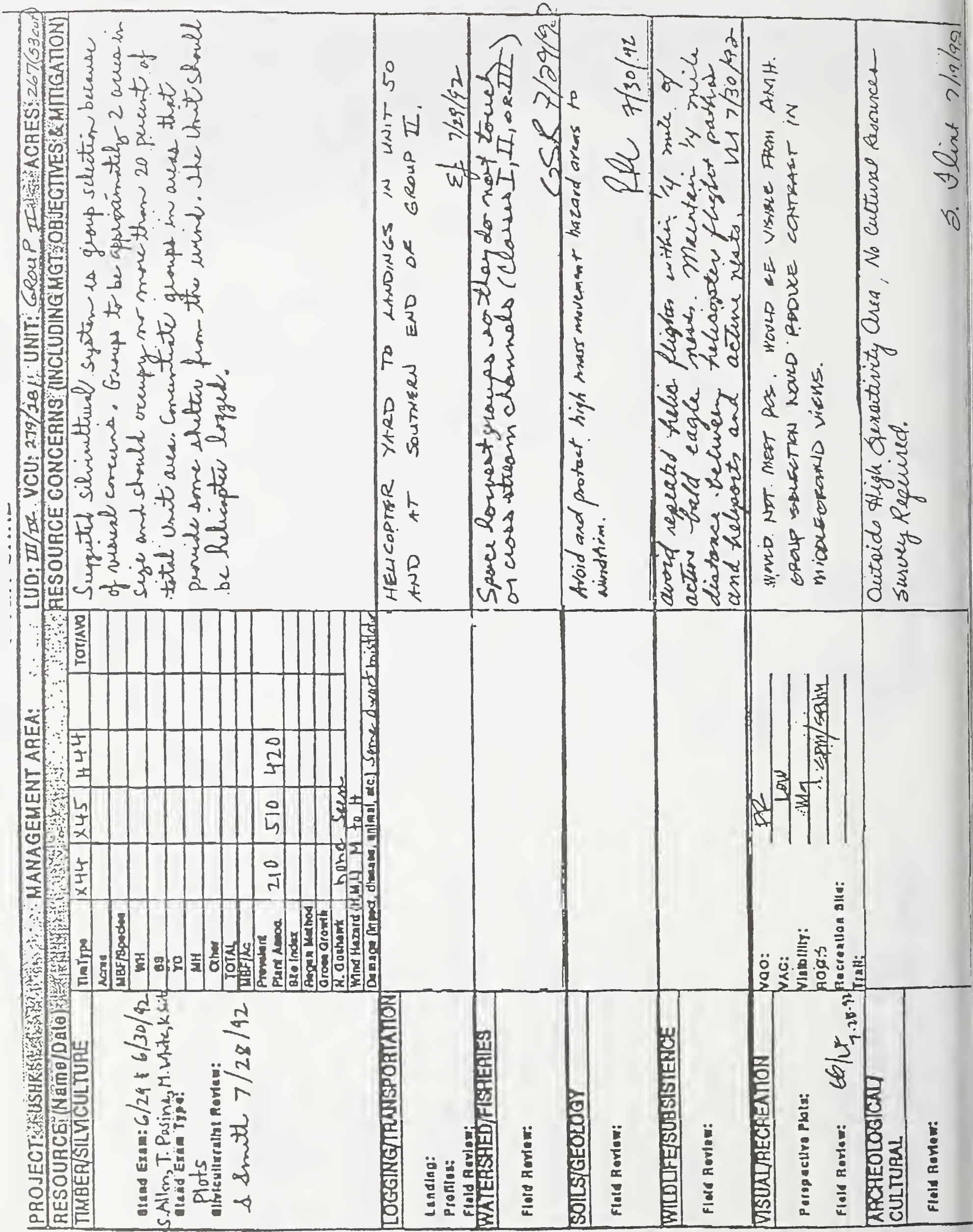




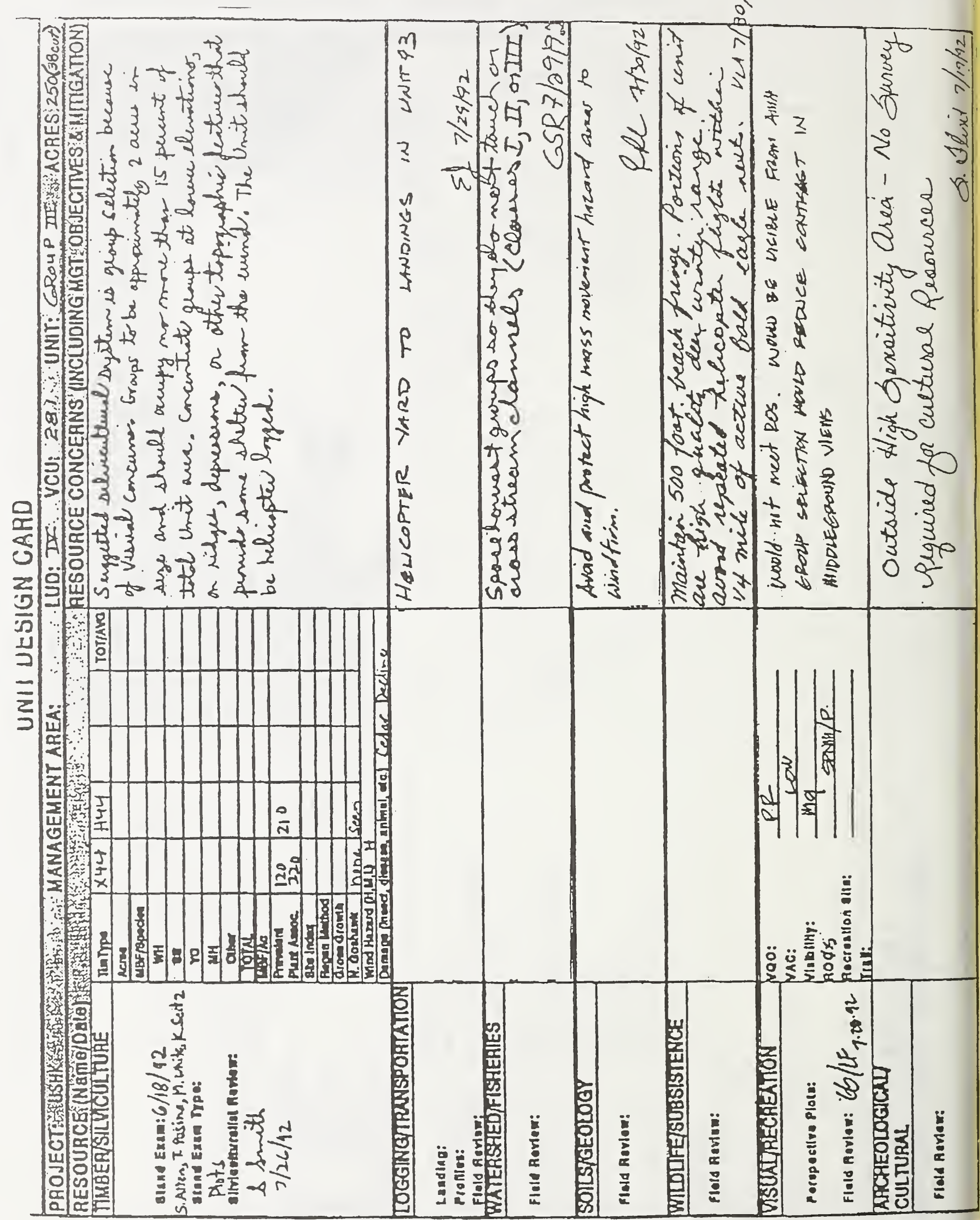


Appendix 3

Road Management

Objectives (RMOs) for the Selected Alternative 



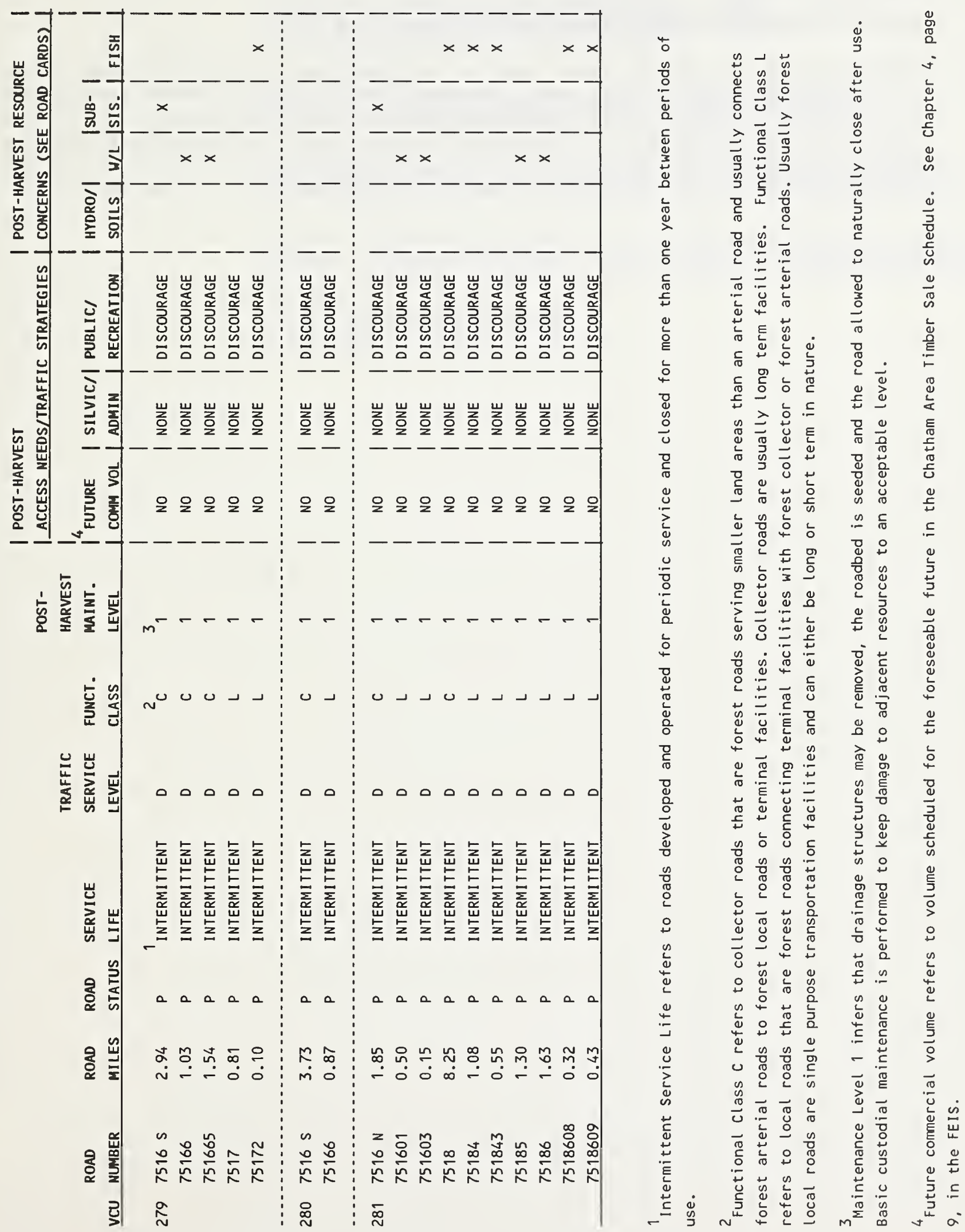




\section{Appendix 3 R.O.D.}

Note to the Selected Alternative Road Management Objectives

Road number $7516 \mathrm{~N}$ in the selected alternative consists of road segments displayed on Road Card number $7516 \mathrm{H}$ and $7516 \mathrm{G}$ as shown in Appendix C of the FEIS. Road number 7516S in the selected alternative consists of road segments displayed on Road Card number 7516A, 7516B, 7516C and portions of 7516D and 751607 as shown in Appendix $C$ of the FEIS. Road number 7518 in the selected alternative consists of road segments displayed on Road Card number $7518 \mathrm{C}, 7518 \mathrm{~B}$ and a portion of $7518 \mathrm{~A}$ as shown in Appendix $\mathrm{C}$ of the FEIS. These road segments are for major transportation links that are too long to display on a single road card at a reasonable scale. 


\section{Appendix 4 Proportion of Volume Classes 6 and 7 Planned for Harvest in the Selected Alternative}





\section{Proportion of Volume Classes 6 and 7 Planned for Harvest for the Selected Alternative}

The following is a summary of the analysis of the planned timber harvest for the Selected Alternative to determine compliance with the proportionality requirement of the Tongass Timber Reform Act (TTRA), Section 301(c)(2). This determination was made following the procedure contained in Forest Service Handbook 2409.18 Region 10 Supplement No.

2409.18-93-3. Tables 4-1 and 4-2 show the current land base distribution of volume classes and proportionality projections for the Selected Alternative based on the GIS TIMTYP layer per handbook direction.

Table 4-1

Selected Alternative - TTRA Proportionality for Management Area C39

\begin{tabular}{|c|c|c|c|c|}
\hline & $\begin{array}{c}\text { Total } \\
\text { Timber } \\
\text { Base } \\
\text { (acres) }\end{array}$ & $\begin{array}{c}\text { Volume } \\
\text { Classes } \\
4 \text { \& } 5 \\
\text { (acres) }\end{array}$ & $\begin{array}{c}\text { Volume } \\
\text { Classes } \\
6 \text { \& } 7 \\
\text { (acres) }\end{array}$ & Proportionality \\
\hline Current Land Base & 11,243 & 10,949 & 294 & $2.61 \%$ \\
\hline $\begin{array}{l}\text { Selected Alternative } \\
\text { Planned Harvest }\end{array}$ & $-1,581$ & $-1,539$ & -41 & \\
\hline Projected Proportionality & 9,662 & 9,410 & 253 & $2.62 \%$ \\
\hline \multicolumn{5}{|l|}{ Source: Regan, 1994} \\
\hline \multicolumn{5}{|c|}{ Note: This data was derived from the Chatham Area GIS, TIMTYP data layer } \\
\hline \multicolumn{5}{|c|}{ Proportionality $=($ Volume Classes $6 \& 7$ acres $/$ Total Timber Base acres $) \times 100$} \\
\hline
\end{tabular}

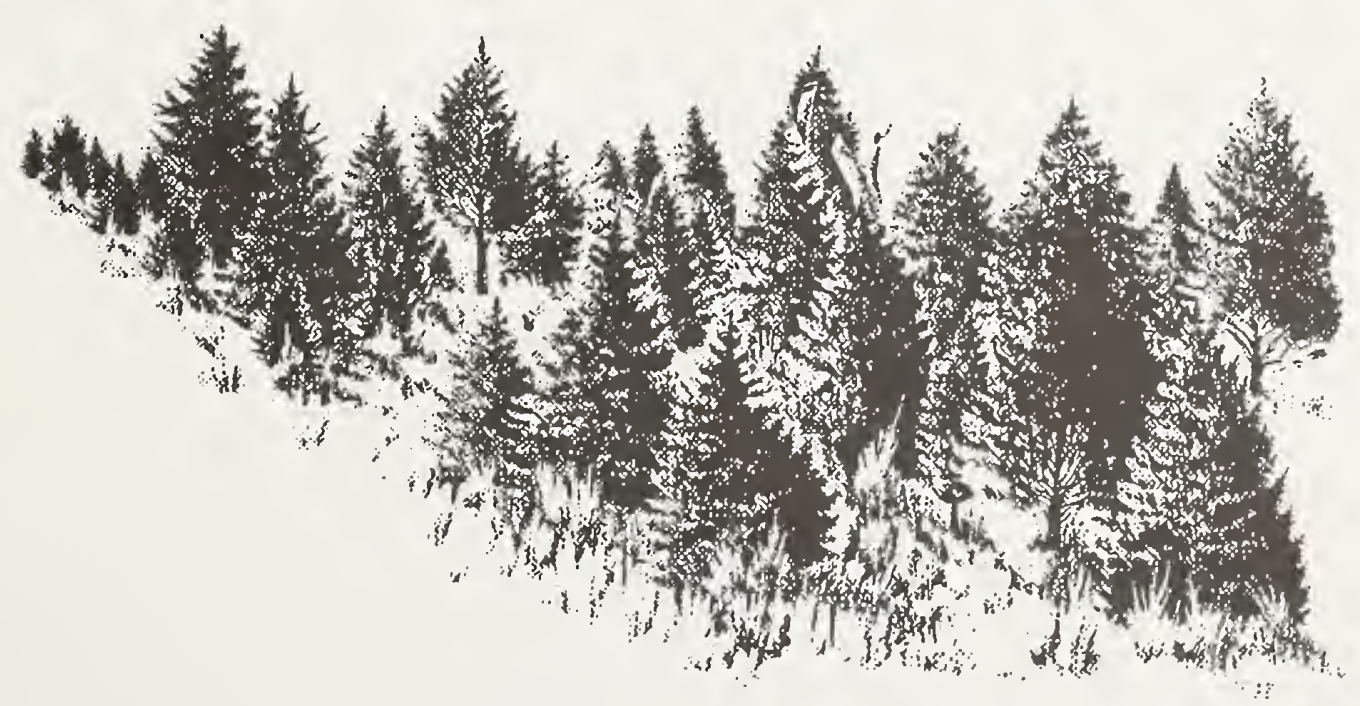


Table 4-2

Selected Alternative - TTRA Proportionality for Management Area C40

\begin{tabular}{lrrrr}
\hline & $\begin{array}{c}\text { Total } \\
\text { Timber } \\
\text { Base } \\
\text { (acres) }\end{array}$ & $\begin{array}{c}\text { Volume } \\
\text { Classes } \\
\begin{array}{l}4 \text { \& } 5 \\
\text { (acres) }\end{array}\end{array}$ & $\begin{array}{c}\text { Volume } \\
\text { Classes } \\
6 \& \text { \& } \\
\text { (acres) }\end{array}$ & Proportionality \\
\hline Current Land Base & 52,331 & 51,867 & 464 & $0.89 \%$ \\
$\begin{array}{l}\text { Selected Alternative } \\
\begin{array}{l}\text { Planned Harvest } \\
\text { Projected Proportionality }\end{array}\end{array}$ & -595 & -590 & -5 & \\
\hline
\end{tabular}

Source: Regan, 1994

Note: This data was derived from the Chatham Area GIS, TIMTYP data layer

Proportionality $=($ Volume Classes $6 \& 7$ acres $/$ Total Timber Base acres $) \times 100$

The Selected Alternative is projected to result in proportionality consistent with the requirements of the TTRA for Management Areas C39 and C40. 


\section{Appendix 5 Selective Harvest Evaluation Monitoring}





\section{Monitoring}

The following is a description of the effectiveness monitoring activity expected to take place in conjunction with the Ushk Bay Selected Alternative in addition to the monitoring activities described in the FEIS Appendix I.

Selective Harvest

Objective:

To evaluate the effectiveness of the selective harvest prescriptions for Groups I, II, and III in mitigating visual impacts along the ferry route in Peril Strait

Desired result: The Groups will not experience management induced windthrow because of the selective harvest prescriptions and will meet a Visual Quality Objective of Partial Retention

Measurement: Calculate the VQO following timber harvest and periodically spot-check the Groups windfirmness

Evaluation: Determine if a Partial Retention VQO was achieved and if the residual trees within Groups are windfirm

Responsible staff: Landscape Architect and District Timber staff

Record of results: Results documented in a short report to Forest Supervisor

Annual cost: $\quad \$ 1,000$

Personnel needs: None 

The United States Department of Agriculture (USDA) prohibits discrimination in its programs on the basis of race, color, national origin, sex, religion, age, disability, political beliefs and marital or familial status. (Not all prohibited bases apply to all programs.) [sic] Persons with disabilities who require alternative means for communication of program information (braille, large print, audiotape, etc.) should contact the USDA Office of Communications at (202) 720-5881 (voice) or (202) 720-7808 (TDD).

To file a complaint, write the Secretary of Agriculture, U.S. Department of Agriculture, Washington, D.C., 20250, or call (202) 720-7327 (voice) or (202) 720-1127 (TDD). USDA is an equal employment opportunity employer. 


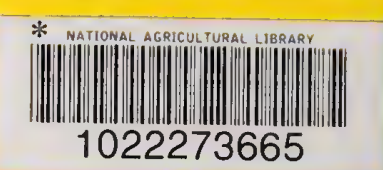

